\title{
Kahdeksantavuinen säe pohjoisen Euraasian laulustossa
}

Tarkastelen tässä kahdeksantavuisen laulusäkeen levikkiä ja menneisyyttä Euroopan ja Aasian pohjoisilla alueilla. Siperialaisen ja kanta-amerikkalaisen laulun tyyliyhtäläisyydet ovat kiistattomat. "Siperialaiseen" kuuluvat myös läntisten saamelaisten joiku ja itäisten leutte, mutta miten näihin suhteutuu karjalainen $i t k u$ tai suomalainen virsi, jolla tarkoitan tässä kalevalamittaista runolaulua.

Itämerensuomalaiset ovat saanut vahvoja vaikutteita sekä muinaisbalteilta että -germaaneilta. Germaanisten vaikutteiden vuoksi mm. suomalaisen kielisysteemin monet pintarakenteet muuttuivat syvällisesti pronsikaudella, kolmisen vuosituhatta sitten ${ }^{1}$. Niin ikään laulajien perinne oli saanut varsinkin rautakaudella niin väkeviä lainoja varsinkin Pohjois-Saksan ja Etelä-Skandinavian väestöiltä ${ }^{2}$, että kalevalamittaisen perinteen taitajan nimenä oli runoi ja runoija eli oman aikamme 'runoilija'. Toisaalta on olemassa vankka käsitys ${ }^{3}$, jonka mukaan kalevalamittainen runous on sukua idän kahdeksantavuisuudelle, ja että kyse on jo vuosituhansia vanhasta systeemistä, joka kulkeutui länteen silloin, kun Volgalta Itämerelle levittäytyneillä suomalais-ugrilaisilla oli suhteellisen yhtenäinen kulttuuri ja (suomalais-volgalainen) kieli. Tässä artikkelissa aion puuttua kahdeksantavuisuuden ongelmaan lähinnä äänitteiden perusteella ikään kuin uutena asiana: en välitä suuremmin siitä, mitä aiheesta on aiemmin kirjoitettu.

Euraasian arktisessa laulustossa on mitä erilaisimpia tyylejä. Yleensä laulu on yksiäänistä, mutta on myös moniäänisyyttä; on vapaata metriikkaa ja metristä säännönmukaisuutta. Kiinteämetrisyys pohjautuu erilaisille mittasysteemeille. Tässä keskitytään sellaiseen, jossa säe rakentuu neljän nousun ja vastaavasti neljän (ideaalitapauksessa yksitavuisen) laskun varaan. Keskeisiä kysymyksiä on kaksi: missä kahdeksantavuisuutta esiintyy ja miten eri kansojen perinteet suhteutuvat toisiinsa. 


\section{A. Aineiston esittely}

\section{A.1. Itämerensuomalaisen virren trokee}

Kalevalamittaa on käytetty suppeahkolla alueella, jonka ovat muodostaneet Suomi, Karjala Inkeri, Vatja, Viro ja pohjoinen Liivinmaa. Se puuttuu sekä vepsäläisten että saamelaisten laulustosta. Klassisen kalevalamitan synty on sijoitettu rautakaudelle, parin vuosituhannen taakse, mutta sitä oli oletuksen mukaan edeltänyt yksioikoisempi mitta. Senkin säkeessä oli ollut 8 tavua, ja sen jakoi kahtia kesuura ${ }^{4}$.

Virsien sävelmät on sijoitettu metriseen pohjakaavaan, joka koostuu neljästä trokeisesta runojalasta: paino on jalan alussa eli nousussa:

$$
\begin{array}{cccccc}
12 & 34 & 56 & 78 \\
+\mathrm{o} & +\mathrm{o} & +\mathrm{o} & +\mathrm{o}
\end{array}
$$

Tällainen systeemi soveltuu hyvin moniin uralilaisiin kieliin, joissa sanan pääpaino (2) on sanan ensitavulla ja sivupaino (I) kolmannella:

$\begin{array}{llllllllllllll}2 & 0 & 1 & 0 & 2 & 0 & 1 & 0\end{array}$

kau-hi- a- han, kau- pun- ki- hin
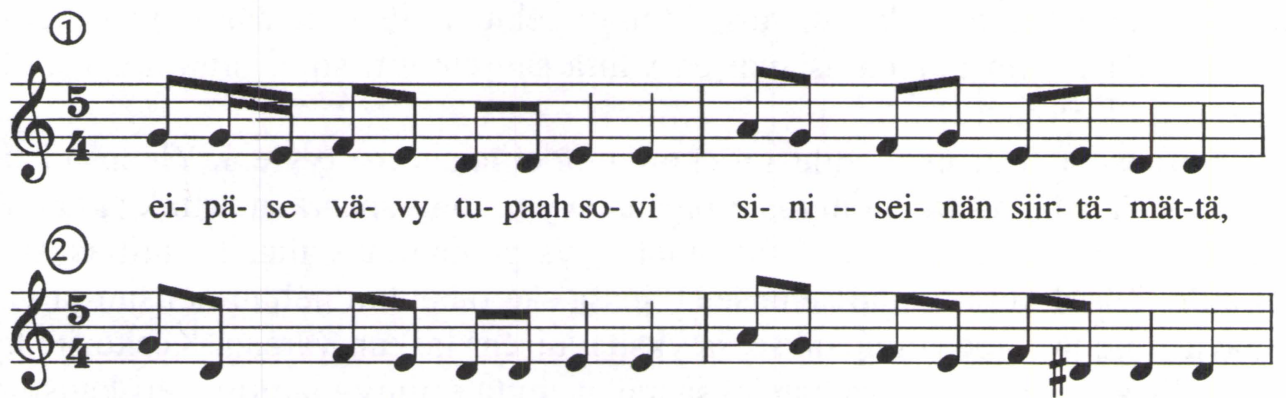

si-- ni -- sei-nän siir-tä- mät- tä, ka-man-- jo ko-- hot-ta - mat-ta.

Nuottiesimerkki $1^{* *}$. 


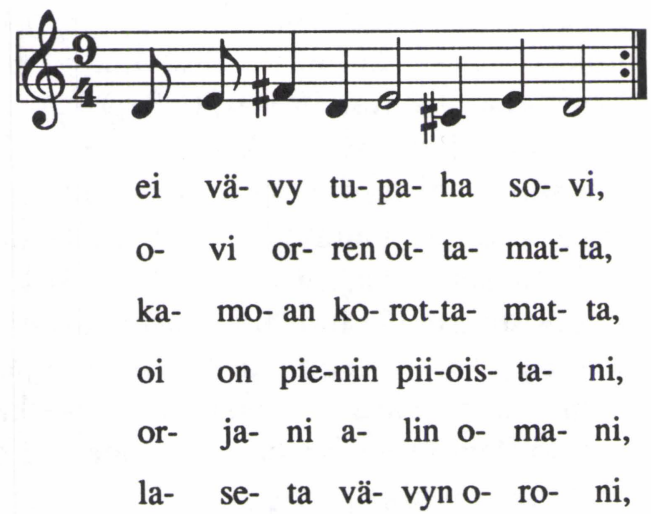

\section{Nuottiesimerkki 2**.}

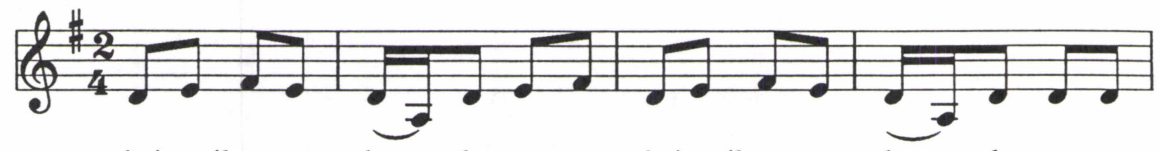

kui meil e- mä koo- le nes- se, kui meil e- mä koo- le- nes-se,
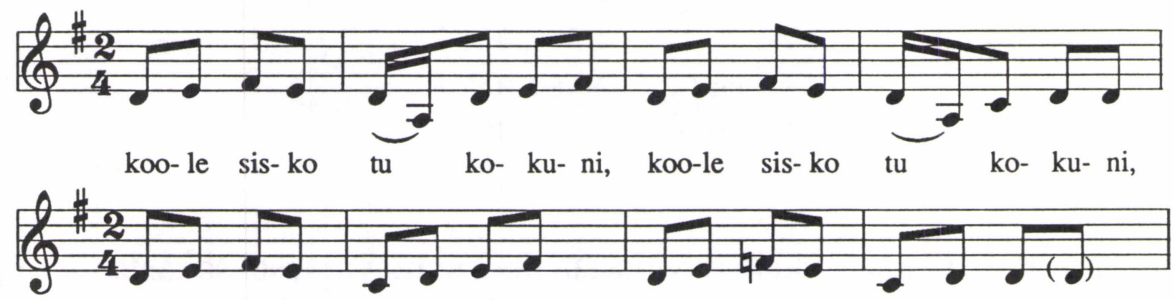

e- mä au- ta las- ta- nes- se, e- mä au- ta las- ta- nes (-se)

\section{Nuottiesimerkki $3^{* *}$.}

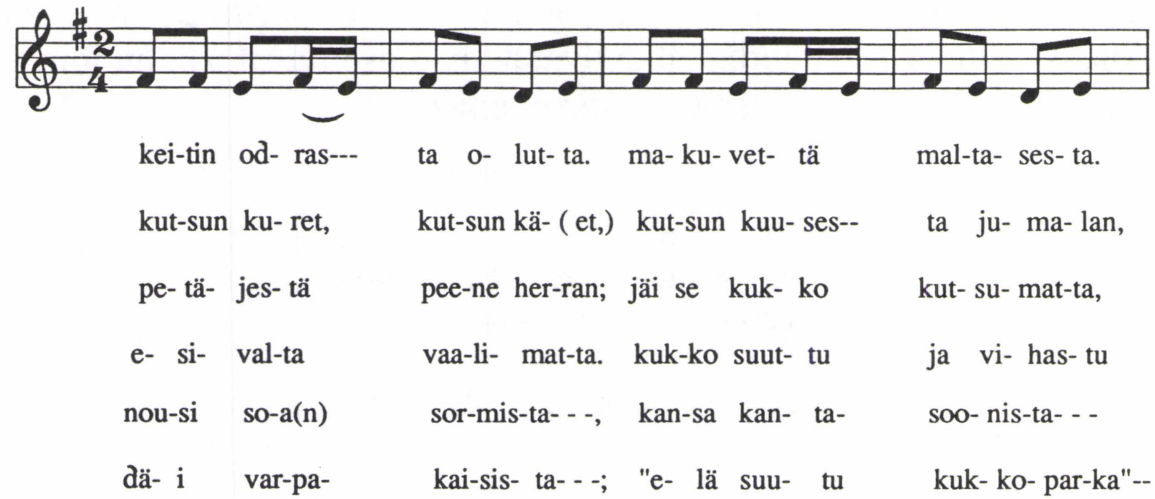

\section{Nuottiesimerkki $4^{* *}$.}


Nuottiesimerkit 1-4. Itämerensuomalaisia virsisävelmiä. 1. Vävyn virsi. Lauloi Petter Mansinen, s. 1901: Tuupovaara. (Äänite: KPL.) 2. Vävyn virsi. Lauloi Domna Huovinen, s. 1878) Kontokki Vienan Karjalassa. (Äänite: KPL.) 3. Ema ja armud. Lauloi Kadri Kukk, Karksin kylä. (Äänite: ERMA: II, 32.) 4. Kull kutsumata. Lauloi Oudekki Figurova s. 1891, Rajon kylä, Vatja (Äänite: VIR II, 20).

Mainittakoon tässä, että nuotinnokset ovat kirjoittajan, mikäli toisin ei ilmoiteta. Olen joutunut kirjoittamaan monien laulujen tekstit kieltä taitamattomana vain kuulohavainnon varassa. Tällaiset notaatiot on merkitty kahdella tähdellä $(* *)$. Painotan tässä sitä, että kiinnostukseni kohdistuu konsonanttien yhteydessä oleviin vokaaleihin, joiden avulla olen pyrkinyt seulomaan esiin lauluja, joita mahdollisesti ohjailee kahdeksantavuinen metrinen kaava. Tekstit ovat leksikaalisesti arvottomia ja virheellisiä Kirjoitus on kuitenkin ensiyritys. Hypoteeseja on tarkoitus testata yhteistyössä lingvistien kanssa.

Tekstissä kesuura näkyy pilkkuna säkeen keskellä. Yllä olevaa voidaan kuvata kaaviona seuraavalla tavalla: plusmerkki osoittaa runojalan nousun ja nolla sen painottoman laskun. Melodian rytmi mukautuu tekstin mittasysteemiin:

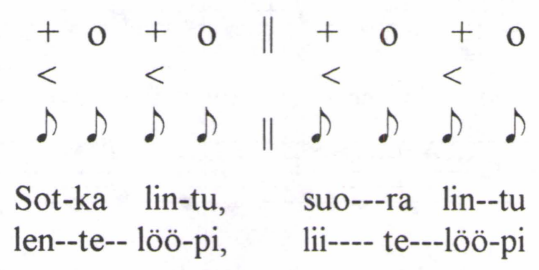

Säe muodostuu joko 4 kaksitavuisesta tai 2 nelitavuisesta sanasta ilman, että sanat ylittävät kesuuran. Pääpainot osuvat jalan nousulle ja painottomat laskulle, joten sanapaino ja metrinen paino osuvat yhteen. Näin musiikillinen ja prosodinen pulsaatio vastaavat toisiaan. Klassiselle kalevalamitalle on ominaista se, että sana jatkuu kesuuran yli. Klassiseen mittaan liittyy myös murrelmasäkeenä tunnettu ratkaisu: sanan ensitavu eli pääpaino osuu laskuun, mitan painottomaan vaiheeseen. Näin sanojen painot ovat ristiriidassa metrisen painon kanssa. Oheisen esimerkin alleviivatut tavut osoittavat painot, joissa riistiriitaa ei ole, ja kursivointi osoittaa murrelmavaiheet:

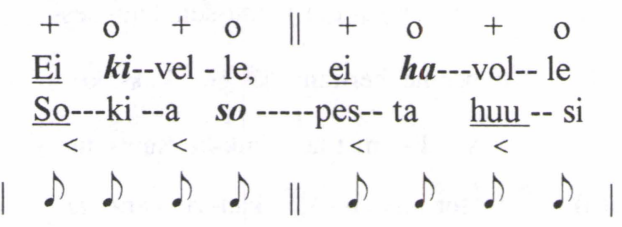




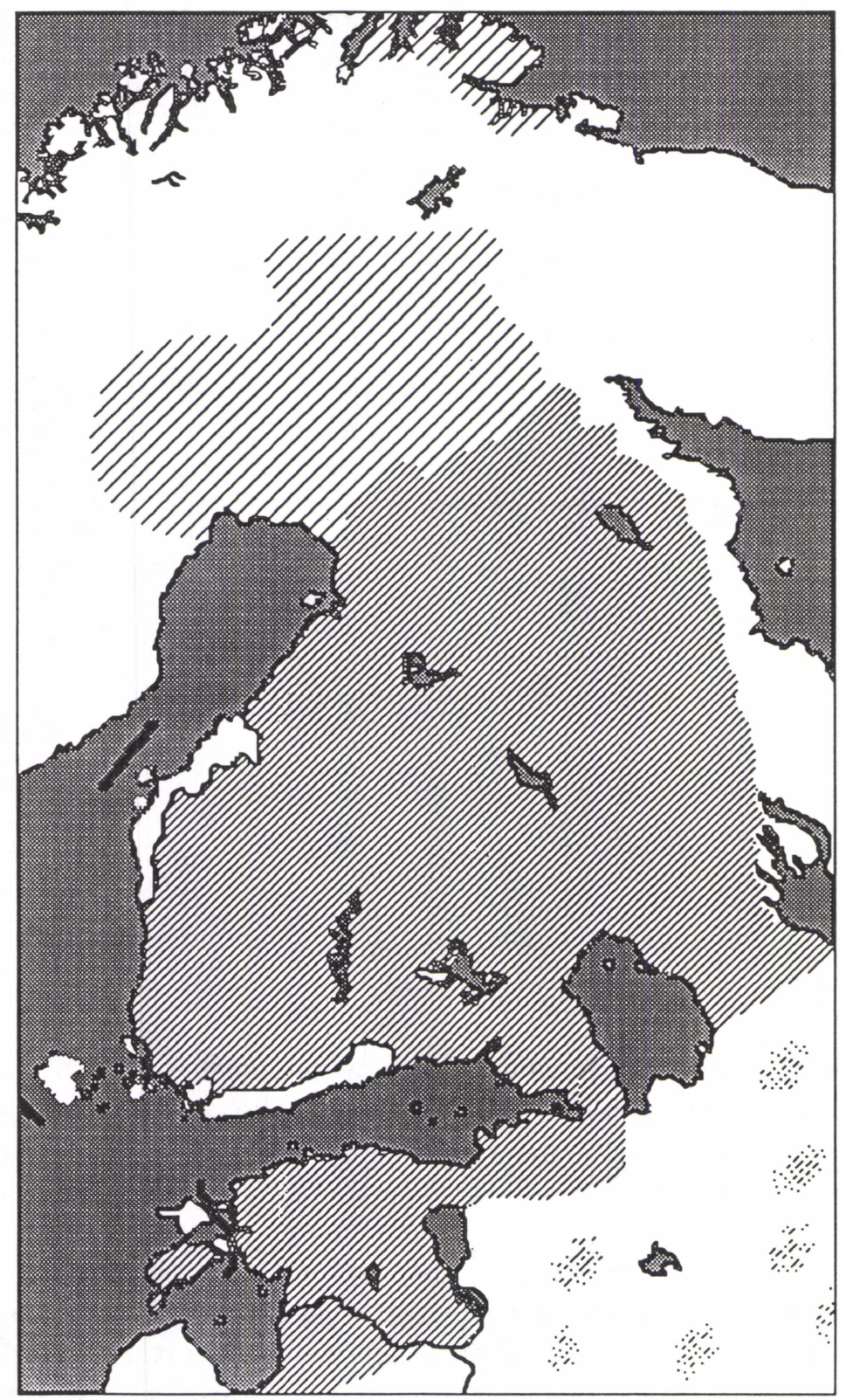

Kartta 1. Kalevalamitan päälevikki itämerensuomalaisella alueella. Ruijan viivoitus pohjoisessa liittyy kveeneihin. Pisteryhmät kaakossa osoittavat, mihin Karjalan pakolaiset asettuivat paettuaan 1600-luvulla suurvallaksi nousemassa olleen Ruotsin pakkoluterilaistajia. 
Itämerensuomalaisella alueella ensimmäisessä runojalassa voi olla 2, 3 tai 4 tavua, muissa vain 2 . Kahdeksantavuisena metrinen pohjakaava voidaan toteuttaa eri tavuyhdistelmin. Laatikossa luvut ilmaisevat sanassa olevien tavujen lukumääriä.

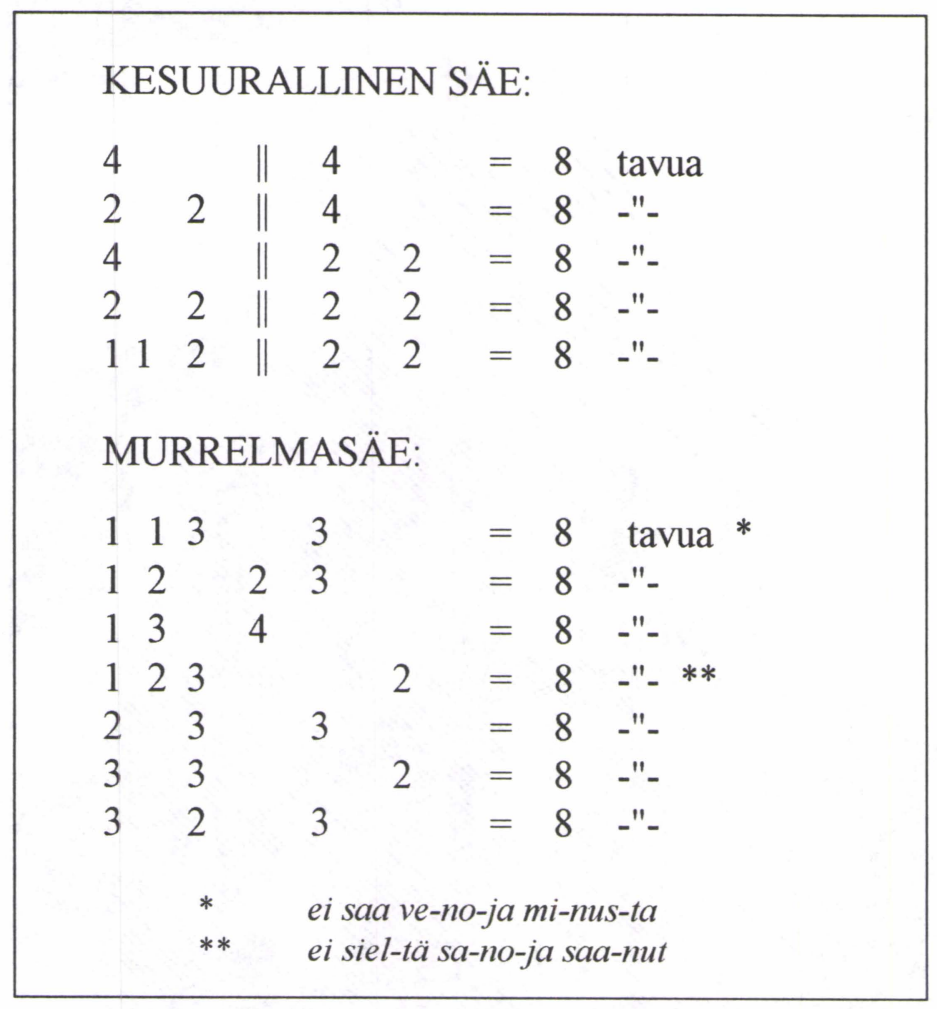

Nuottiesimerkistä 1 voi havaita itämerensuomalaisten virsien melodioiden luonteenomaisia yleispiirteitä. Tarkkoja tyylianalyyseja ovat tehneet ennen kaikkea Ilkka Kolehmainen kalevalansävelmästä ja Ingrid Rüütel Viron ja sen lähialueiden tyylipiirteistä5 .

1) Sävelmä etenee syllabisesti: yksi tavu yhtä säveltä kohti.

2) Suurmuotona on iteraatio eli säkeistöiksi jakautumaton säejono.

3) Musiikin perusrakenteena on tekstisäkeen mittainen sävelmäsäe. Iteroivana yksikkönä on joko yksi sävelmäsäe tai kaksi sellaista sävelmäsäettä, jotka eroavat toisistaan hyvin vähän.

Esimerkeistä 1 ja 3 näkyy, että kaksisäkeisen perusyksikön säkeiden välinen ero on usein hyvin pieni mutta hahmotuksen kannalta ratkaiseva. Mm. Ingrid Rüütel on arvellut, että mm. Virossa ja Vatjassa yksisäkeinen rakenne on kaksisäkeistä vanhempi. Toisaalta Suomessa on esiintynyt myös nelisäkeisiä rakenteita. Ne ovat suhteellisen uutta ja tämän tutkimuksen kannalta toisar- 
voista perinnettä, jolla on Länsi-Euroopan säkeistöllisyydestä saatuja malleja. Toisaalta erityisesti kaksisäkeisyys yhdistää suomalaiset ja karjalaiset pohjoissaamelaisiin, joiden joiuissa keskeisenä muotoperiaatteena on kahden hieman toisistaan poikkeavan säkeen yhdistäminen iteratiiviseksi säepariksi.

4) Eri laulujen musiikillinen metriikka vaihtelee ${ }^{6}$, mutta oli se mikä tahansa, se säilyy samana alusta loppuun. Koska teksti pysyy isosyllabisena (siis kahdeksantavuisena), melodia pysyy isometrisenä.

5) Laulaja voi muunnella melodiaa, jonka kriittisiin kohtiin hän ei kuitenkaan kajoa. Tällaisia kohtia ovat ennen kaikkea päätösformulat.

6) Terssin laajuus saattaa vaihdella (ks. esimerkkiä 3 ).

7) Moodit ovat kapeita: niissä on 3, 4 tai 5 peräkkäistä säveltä.

8) Varsinkin kaksisäkeisten laulujen sävelet saattavat käyttäytyä kuin duurin tai mollin vastaavat sävelet, mutta geneettisesti piirre ei kuulu läntisen Euroopan hoveissa syntyneeseen tonaaliseen traditioon ${ }^{7}$.

9) Kaksisäkeisissä lauluissa tonaalinen keskus on useimmiten sama kuin jälkisäkeen päätössävel. Yksisäkeisissä tonaalisen keskuksen määrittäminen voi olla hankalaa, mutta kuten Heikki Laitinen tästä on todennut: "Laulamalla tonaalinen keskus löytyy melkein aina kiistattomasti ja kokemukseni mukaan varsin yksimielisesti" ${ }^{\prime}$. Esimerkissä 4 säkeen päätössävel on todellisuudessa siirtymäsävel (eli melodinen ponnahduslauta) kohti seuraavan säkeen alkua. Täten päättävää säveltä notaatiossa ei ole, mutta toki siinä on tonaalinen keskus.

Seuraavassa tarkastellaan Siperiaa kahdeksantavuisuuden näkökulmasta. Tarkastelu etenee karkeasti ottaen Siperian itäosista länttä kohti (ks. kartta 2). Tässä kirjoituksessa mainituista kansoista ajankohtaisinta perustietoa saa virolaisten hiljan toimittamasta kirjasta "Vene impeeriumi rahvaste punane raamat" (Kolga et al. 1993) ja kielistä myös esim. Comrie 1981.

Ennen analyysin alkua on syytä mainita pari asteikkoanalyysissä käyttämääni näkökulma. Kordisissa asteikoissa ei ole ongelmia, sillä sävelet järjestyvät diatonisesti ja siten asteiden tulkinnassa ei ole ongelmia, kun ykkönen vastaa perussäveltä:

$\begin{array}{lllllll}\text { sävelet: } & c & d & e & f & g & a \\ \text { asteet: } & 1 & 2 & 3 & 4 & 5 & 6 \\ \text { suhteelliset asteet: } & \text { do } & \text { re } & \text { mi } & \text { fa } & \text { so } & \text { la }\end{array}$

Tilanne muuttuu tulkinnanvaraiseksi, kun kordisissa rakenteissa esiintyy "aukollisia" asteikkoja. Niitä en tulkitse aukollisiksi vaan pentatonisen rakenteen suppeiksi ilmentymiksi täsmälleen saman logiikan mukaan, joka sallii tulkita yllä oleva kordinen rakenne diatonisen seitsensävelikön suppeaksi ilmentymäksi. 
Pentatoniikan erittelyssäni lähtökohtanani on seuraava kaava, joka nousee edellisen kordisen asteikon tapaan $c$-säveleltä:

$\begin{array}{lllllll}\text { sävelet: } & c & d & e & g & a & c \\ \text { asteet: } & 1 & 2 & 3 & 4 & 5 & 1 \\ \text { suhteelliset asteet: } & \text { do } & \text { re } & \text { mi } & \text { fa } & \text { so } & \text { do }\end{array}$

Unkarilaisen Gábor Lükőn ${ }^{9}$ tulkinnan tapaan pidän pentatonista systeemiä itsenäisenä rakenteena enkä heptatonisen asteikon raajarikkoisena (aukollisena) ilmentymänä. Sen vuoksi pentatonisen tarkastelussa asteet määräytyvät samaan tapaan perättäisten sävelten logiikalla kuin heptatonisenkin asteet. Näin $d o$-pentatoninen kvintti on $d o-f a($ eli $c-g)$ kun taas $d o$-heptatoninen kvintti on $d o-s o($ eli sama $c-g$ ).

Yleisen tavan mukaan yllä olevasta asteikosta voidaan rakententaa kaikkiaan viisi erilaista moodia sen mukaan onko moodin lähtösävelenä $d o, r e, m i$, $f a$ vai so:

\begin{tabular}{l|llllllllll} 
absoluuttiset sävelet: & $c$ & $d$ & $e$ & $g$ & $a$ & $c^{l}$ & $d^{l}$ & $e^{l}$ & $g^{l}$ & $a^{l}$ \\
\hline do-pentatoninen: & do & re & mi & fa & so do & & & & & \\
re-pentatoninen: & & do & re & mi & fa & so & do & & & \\
mi-pentatoninen: & & & do & re & mi & fa & so & do & & \\
fa-pentatoninen: & & & & do & re & mi & fa & so & do & \\
so-pentatoninen: & & & & & do & re & mi & fa & so & do \\
\hline
\end{tabular}

Kun siirrytään tarkastelemaan asteikon säveliä modaalisena systeeminä, voidaan käyttää asteita ilmaisevia numeroita. Yllä oleva asteikosto muuttuu silloin järjestelmäksi, jota tässä kirjoituksessa sovellan:

\begin{tabular}{r|llllll} 
asteet: & 1 & 2 & 3 & 4 & 5 & 1 \\
\hline do-pentatoninen rakenne: & $c$ & $d$ & $e$ & $g$ & $a$ & $c^{l}$ \\
re-pentatoninen rakenne: & $d$ & $e$ & $g$ & $a$ & $c^{l}$ & $d^{l}$ \\
mi-pentatoninen rakenne: & $e$ & $g$ & $a$ & $c^{l}$ & $d^{l}$ & $e^{l}$ \\
fa-pentatoninen rakenne: & $g$ & $a$ & $c^{l}$ & $d^{l}$ & $e^{l}$ & $g^{l}$ \\
so-pentatoninen rakenne: & $a$ & $c^{l}$ & $d^{l}$ & $e^{l}$ & $e^{l}$ & $a^{l}$
\end{tabular}




\section{A.2. Paleosiperialainen laulusto}

Muinaissiperialaisten kansojen kuten aleuuttien, eskimoiden, tšuktšien, nivhien, itelmeenien, korjakkien tai keettien lauluissa en ole tavannut jälkiä kahdeksantavuisesta mitasta. Tosin Sahalinin niemimaan nivhit eli giljakit näyttäisivät tunteneen 6 -tavuisen mitan $^{10}$, joka saattaa olla japanilaista vaikutusta. Sen sijaan ainujen kulttuurissa näyttäisi olleen käytössä kahdeksantavuisuus. Ainut ovat alkuperältään tuntematon kansa, ehkä muinoin Siperiaa laajalti asuttaneiden kaukasoidien yksittäinen jäänne. Löytämistäni sävelmistä toinen näkyy nuottiesimerkissä 5 . Niistä toista on ainut ovat laulaneet kuunja auringonpimennyksen yhteydessä. Sen melodia etenee $2 / 4$-metrissä, ja jokaisen säkeen keskellä ja lopussa on kertosäkeenä yhden tahdin mittainen huudahdus: hoi! $!^{11}$ :

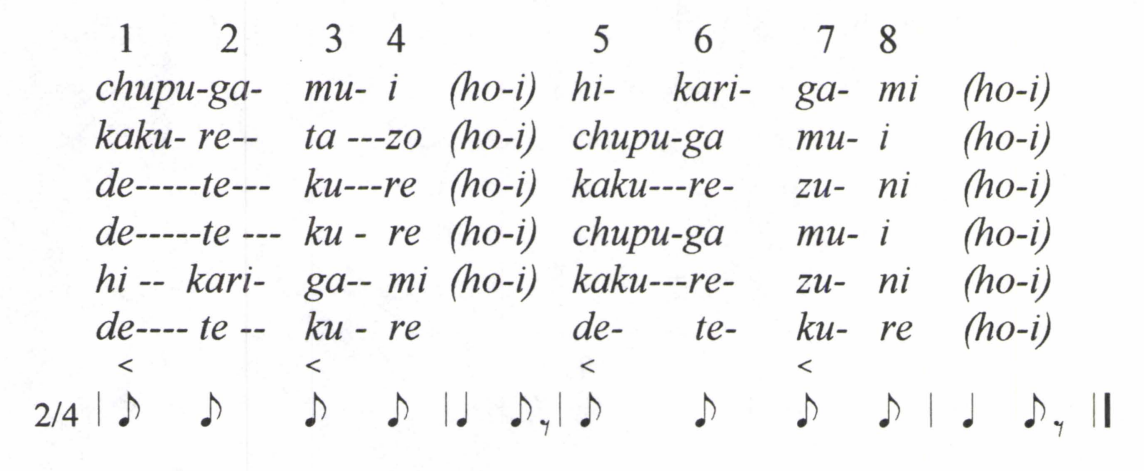

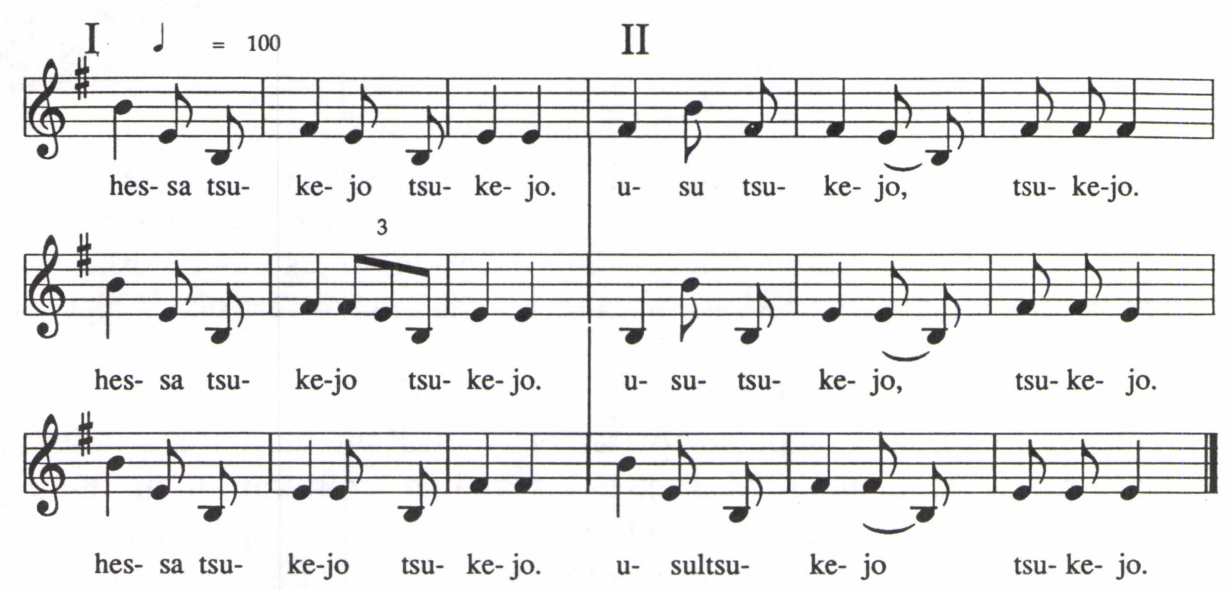

Nuottiesimerkki 5. Vuorolaulu, jota Pohjois-Japanin ainut ovat laulaneet työskennellessään huhmaren ääressä. Toisin kuin yllä olevassa esimerkissä, tässä kahdeksantavuinen säe jakautuu trokeisen jalan jälkeen kahteen daktyyliin $(2+3+3)$, joten laululla ei ole selvää yhteyttä kalevalamittaan. 
Nuottiesimerkin 5 laulua on käytetty rytmittämään survinastioilla työskentelyä. Tämä kahden huhmarenkäyttäjän esittämä sävelmä etenee samassa moodissa kuin auringonpimennyslaulu edellä ${ }^{12}$.

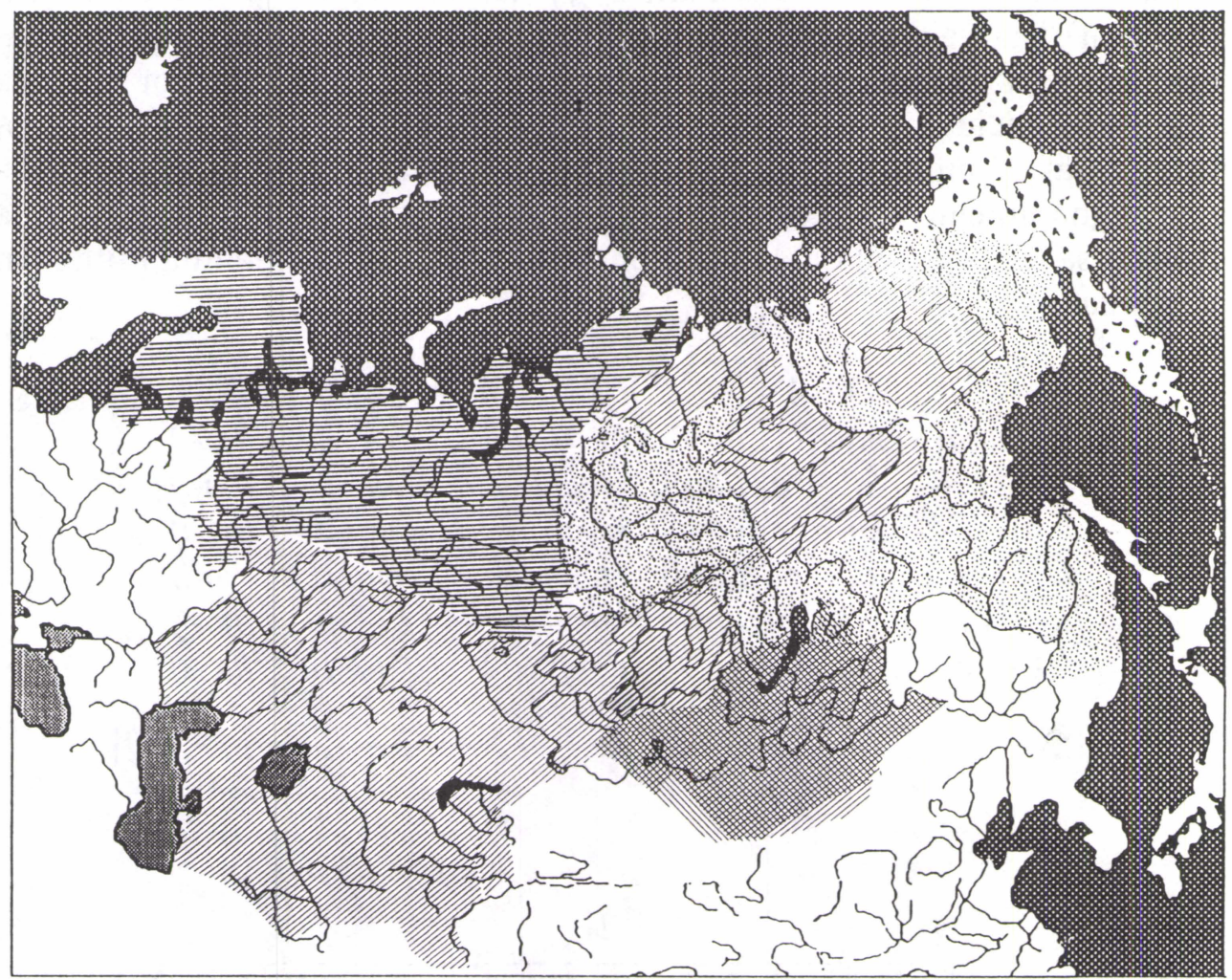

Kartta 2. Siperian kansanryhmien asuialueita. Venäläisalueita ei ole merkitty. Koillis-Siperian isopisteinen alue osoittaa paleosiperialaisten pääasuinseutua. Pienin pistein merkitty alue liittyy tunguuseihin. Vino viivoitus kuvaa turkkilaisten kansojen levinneisyyttä ja ristikkäisviivoitus peittää mongolikansat. Vaakaviivoitus peittää uralilaisten kansojen alueet.

Näyttää siis siltä, etteivät paleosiperialaiset kansat ole tunteneet kahdeksantavuista metristä systeemiä. Tässä yhteydessä jätän ainut vain maininnan varaan, sillä en tunne japanilaisen kulttuurin vaikutuksen mahdollisuutta, ja varsinkin nuotin 5 kaltainen rakenne ei kahdeksantavuisuudestaan huolimatta suoranaisesti liity nelipolvirteokeen yleiskaavaan. Paleosiperialaisten joukossa on ainujen ohessa toinenkin poikkeuksellinen kansa, jukagiirit, jotka asuvat läntisessä Keski-Siperiassa, Jeniseillä. Heihin palataan tuonnempana. 


\section{A.3. Tunguusit}

Tunguusit asuvat yli 10 kertaa Suomen kokoisella alueella Keski- ja Itä-Siperiassa jakautuneena 8 pääheimoon. Siperiassa heitä on noin 57.000 , mutta heidän suurin heimonsa, kolmimiljoonainen mantšu, asuu Kiinassa. Näyttää siltä, että prototunguusit olivat viettäneet liikkuvaa pyytäjäelämää Jenisein ympäristössä ja sen itäpuolella tuhansia ja tuhansia vuosia. Vanhan käsityksen mukaan tunguusit kuuluvat turkkilaisten kanssa altailaiseen kieliperheeseen, mutta tätä nykyä useat tutkijat pitävät heitä omana ryhmänään, joka on vaikuttanut naapureihinsa turkkilaisiin, mongolilaisiin ja samojedilaisiin kansoihin, niin kuin he ovat itsekin saaneet näiltä vaikutteita ${ }^{13}$.
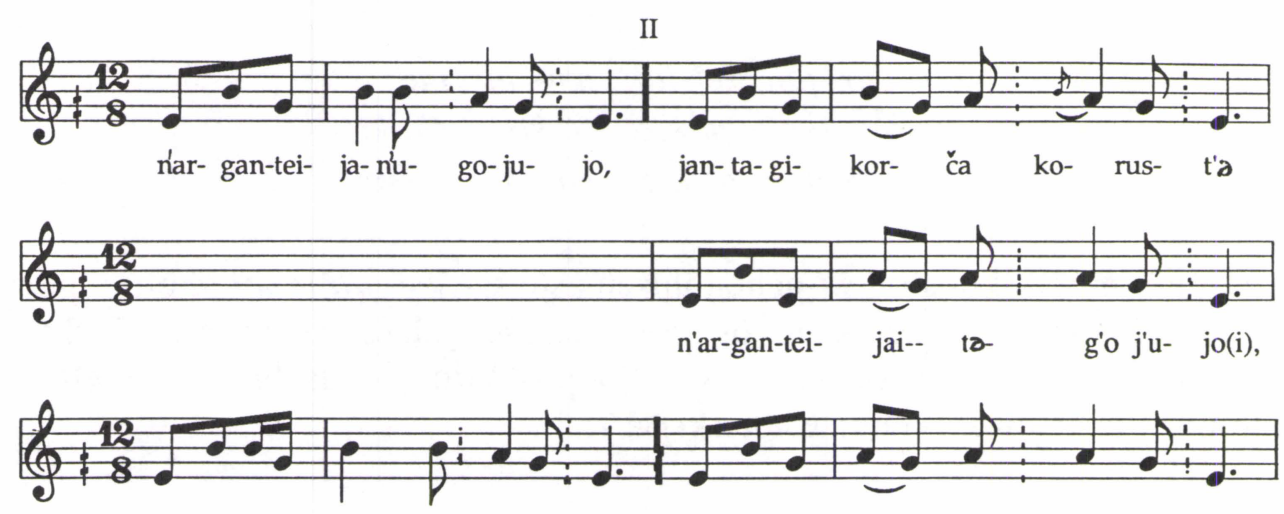

gan-ta- ras- ja- t'a- ga- gor"-jo, je- kun-du- ka- il-- ča-

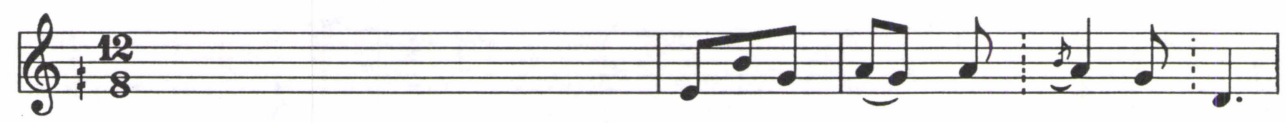

n'ar-gan- tei- jai- ta- g'o- j'u- jo-(i)

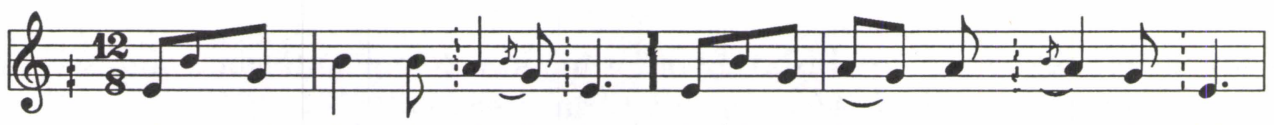

n'ar-gan-tei- j'ai- t'a- g'o- j'u- jo, bug-da- ga- kon- to-- ko- d'u- kil

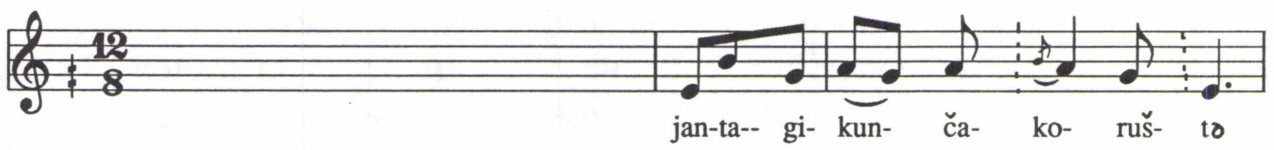

Nuottiesimerkki 6**. Ahmanpyyntiin liittynyt evenkiläinen laulu. (Äänilähde: MSS 2: 35.)

Evenkit ovat Siperian tunguusien suurin heimo. Heidän kuten tunguusien perinteessä yleensäkin esiintyy kahdeksantavuisuuteen viittaavaa laulustoa. Esimerkkinä 6 on evenkien metsästyslaulu, joka on liittynyt ahmanpyyntiin ${ }^{14}$. 
Melodia rakentuu toisistaan vain hivenen eroavasta esi- ja jälkisäkeestä, mikä piirre on tuttu sekä pohjoissaamelaisten joiuille että itämerensuomalaisten kaksisäkeisille virsille. Laulu on oktosyllabinen, mutta yhtenä askarruttavana piirteenä pidän säeryhmitystä. Tunguusien lauluissa ei perinteisesti ole ollut säkeistömuodostusta, mutta tässä laulaja nivoo kolme säettä $(a b b)$ ikään kuin säkeistöiksi. Jarkko Niemi on havainnut, että nenetsien laulustossa kolmisäkeistä muotorakennetta voi luonnehtia yleiseksi. Sen perusteella voi olettaa, että tässäkin tapauksessa rakenne edustaa tunguusien perinteellistä muotoperiaatetta. Tekstin rakenne esimerkissä 6 on siis:

$$
\begin{aligned}
& \text { n'ar-gan tei-ja n'u-go j'u-j'o gan-ta ras-ja t'a-ga gor'-jo } \\
& \text { jay--ta gi-kor ča-korus-t's je-kun du-ka il-ča sal-le } \\
& n^{\prime} a r-g a n \text { tei-jai tə-g'o j'u-jo }{ }^{i} \text { n'ar-gan tei-jai n'u-g'o j'u-j'o(i) }
\end{aligned}
$$

$$
\begin{array}{llll}
\text { n'ar-gan } & \text { tei-jai } & n^{\prime} u-\text { go }^{\prime} & j^{\prime} u-j^{\prime} o \\
\text { bug-da } & \text { ga-kon } & \text { to-ko } & d^{\prime} u-k i l \\
\text { jay-ta } & \text { gi-kun } & \text { ča-ko } & \text { ruš-tə' }
\end{array}
$$

Laulun moodi koostuu so-pentatonisen asteista 1-4: do re mi fa eli $e^{l} g^{1} a^{1}$ $h^{l}$. Sen 12/8-metri tunnetaan myös Suomessa, Karjalassa ja Virossa. Tyyliyhteyttä voi tarkastella vertaamalla sitä Pohjois-Viron Kuusalussa äänitettyyn lauluun $^{15}$, josta on katkelma esimerkissä 7 .

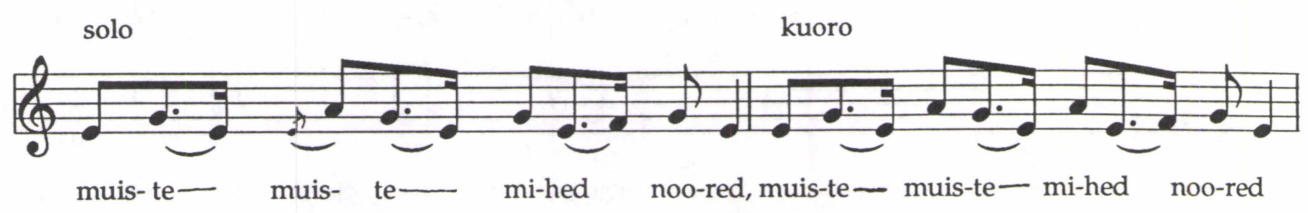

Nuottiesimerkki 7**. Tyylillisesti nuottiesimerkkiä 6 muistuttavan laulun säepari Pohjois-Eestin Kuusalusta: Meri õue all. (Äänitteen lähde: LRA I,1)

Evenkien improvisatoriseksi luonnehdittu laululaji $i k \bar{e} w \bar{n}$ voi rakentua kolmelle isosyllabiselle versifikaatiolle: yksi koostuu 8 tavusta, toinen 10:stä ja kolmas 12 tavusta. Kahdeksantavuisen ikēwünin rakenne voi olla joko yksisäkeisenä $\mathrm{A} A \mathrm{~A}$...A tai kaksisäkeisenä $\mathrm{AB} A B \mathrm{AB}$... $\mathrm{AB}$. Laji on iäkäs, sillä vanhimpien laulujen tekstirippeitä lauletaan yhä kertosäkeinä, vaikka niiden arkaainen kieli on käynyt nykyevenkeille käsittämättömäksi. Evenkien kolmas keskeinen ryhmä koostui laulusaduista tai -tarinoista nimeltään ninmakan. Lajityypillisesti esittäjä kertoo tarinan mutta laulaa sankarin repliikit. Laulusadut kuuluvat myös eveenien perinteeseen. ${ }^{16}$ Kummastakaan lajista en ole tavoittanut näytettä. 
Kaakkois-Siperiassa, Amur-joen itäpuolella asuu nanai-niminen heimo. (Muiden kaakkoisten tunguusiheimojen lailla sitä kutsutaan myös mantöu-tunguusialaiseksi.) Nanaidenkin kulttuurissa on tarinalaji nimeltään nipma. Minulle tuntemattomasta syystä se on ollut naisilta kielletty. Tämä tieto viittaa siihen, että myös ninma kuuluisi laulusatujen ja -tarinoiden ryhmään, sillä syystä tai toisesta nanaiden naiset eivät ole saaneet laulaa kaikkia lajeja. (Syy saattaa liittyä kantananailaiseen kulttuuriin. Nanait nimittäin lienevät alun perin olleet samaa muinaissiperialaista väestöä kuin edellä mainitut ainut ja kaiketi myös nivhit. Nanaiden esivanhemmat olisivat sittemmin tunguusistuneet.) Amurin vastakkaisella eli länsirannalla asuvien $u d e e^{17}$ eli $u d e h e$-naisten tilanne oli aivan toinen, sillä heihin laulukielto ei ulottunut. Udehien kulttuurissa laulutarinat ovat edelleen elävää perinnettä. Nuottiesimerkissä 8 on näyte sävelmästä ${ }^{18}$, jolla tarinan kertoja lauloi sankarihahmon vuorosanat.

Esimerkistä 8 paljastuu mielenkiintoisia seikkoja. Ensinnäkin teksti on säännöllisesti nelinousuinen. Edellä olevan ainulaisen esimerkin 5 lailla tässäkin tekstin neljää runojalkaa seuraa kertosäe, joka tässä on wauwand'ee. Jos nelinousuista vaihetta kuvataan $a$ :lla ja kertoa $b$ :llä, tekstin muotorakenteena on iteratiivinen ketju $a b a b \ldots a b$ :

\begin{tabular}{|c|c|c|c|c|c|}
\hline \multicolumn{2}{|c|}{$a$} & $b$ & \multicolumn{2}{|c|}{$a$} & $b$ \\
\hline 12 & 3 & & 56 & 7 & \\
\hline ðau-je & ðau----je & $W A U-W A N-D^{\prime} E-E$ & ðau-je & ðau--je & $W A U-W A N-D^{\prime} E-E$ \\
\hline$a k a-\partial i$ & hulem-ðä & $W A U-W A N-D^{\prime} E-E$ & tuva-d'e & hulem-ðä & $W A U-W A N-D^{\prime} E-E$ \\
\hline daj-m'e & hulu-je & $W A U-W A N-D{ }^{\prime} E-E$ & goi--ə & $d^{\prime} a--n \partial$ & $W A U-W A N-D^{\prime} E-E$ \\
\hline$d^{\prime} a g-d a$ & dela-v'e & $W A U-W A N-D^{\prime} E-E$ & $d a u-w a$ & halo--an'e & $W A U-W A N-D^{\prime} E-E$ \\
\hline$b a-m^{\prime} e$ & $b a--m^{\prime} e$ & $W A U-W A N-D^{\prime} E-E$ & hoh-to & $n a--w e$ & $W A U-W A N-D^{\prime} E-E$ \\
\hline
\end{tabular}

Melodia puolestaan muodostuu kolmesta osaelementistä. Ensinnäkin on säe $A$, jota seuraa kertosäkeen melodia $C$. Tämän jälkeen tulee $A$ :n komplementti $B$, jota seuraa kertosäe $C$. Näin siis toistuva sävelmäyksikkö koostuu muodoltaan neliosaisesta säeparista, teksti taas kaksiosaisesta:
tekstin säepari:
$a b \quad a b$
melodian säepari:
$A C B C$.

Jos melodian pelkistää jättämällä kertosäe $C$ pois, muoto vastaa täsmälleen itämerensuomalaisten kaksisäkeistä rakennetta: laulu koostuu esi- ja jälkisäkeen $(A B)$ toistosta neljän pentatonisen sävelen kannattamana: $h e^{l} g^{l} a^{l}$ eli fa do re mi. Jos sävel $e^{l}$ katsotaan perussäveleksi, sävel $h$ on sen alapuolinen neljäs aste. Moodin voi siis tulkita $s o$-pentatoniseksi ja johtaa kanta-asteikosta 

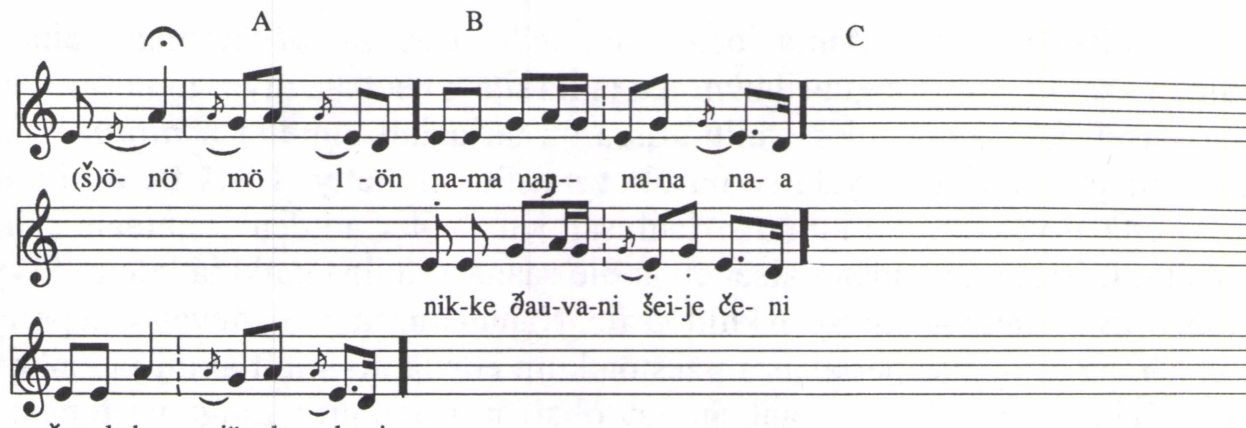

šen-de ho jän-de le-ni
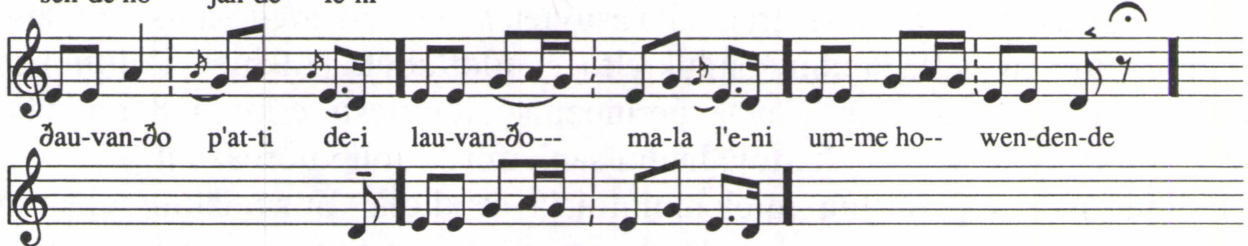

na mo-dan šav-va-ni mor-an he-e
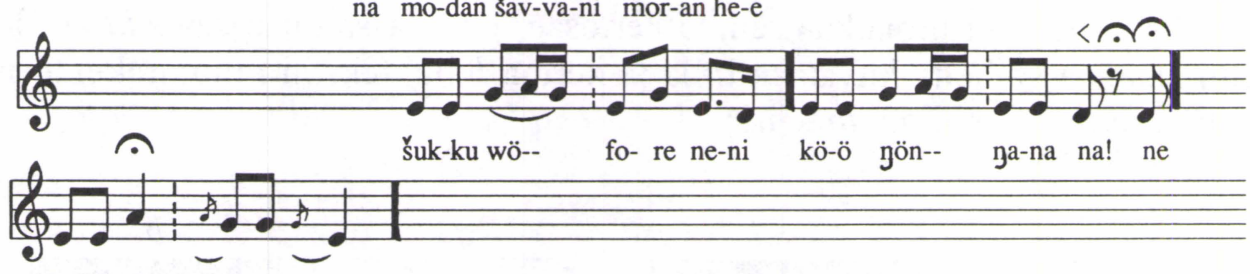

boi-ge fö bu-a- ne

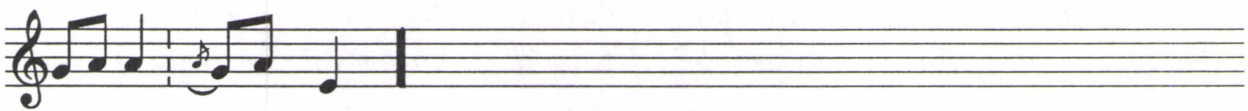

kom-ba ba le- ne

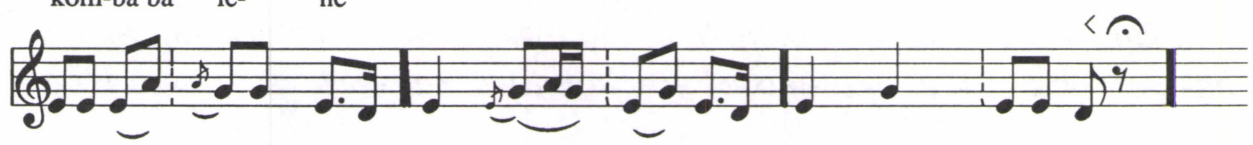

bla-ha-re bu-a- ne-e la- haß_ dö- ne-ni gö dön na-na-na
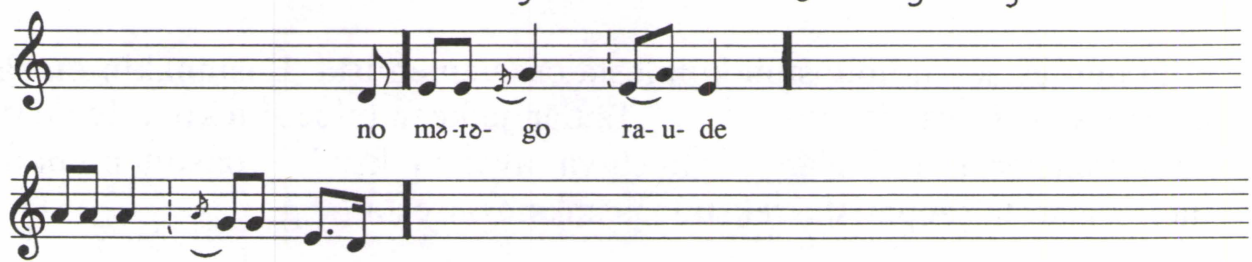

do-be-n'e köh-te- de- ne

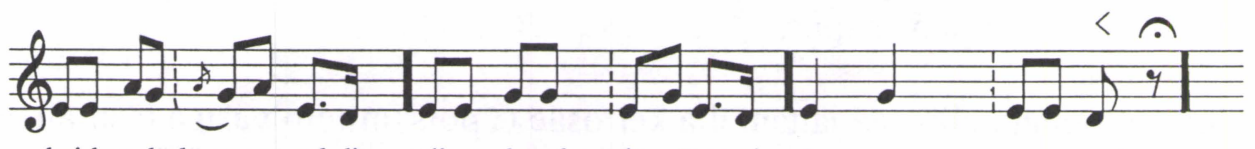

bai-kan dö-lö za-ra sel-din nih-tą lum-be jö- zö se-ni ko- ną ja-na-na'

Nuottiesimerkki $8^{* *}$. Udehe-naisen laulama sävelmä Amurin sivujoelta, Bikiniltä. Laulu kuuluu tarinaan, jossa sankari puhui tämän sävelmän kautta. Lähde: Juri Šeikinin äänite, KPL. 
$e^{l} g^{l} a^{l} h^{1} d^{l}$, josta on valittu moodiin vain asteet $4,1,2,3$. Sattumaa eli ei, niin so-pentatoninen tetrakordi on sekä tämän udehe-esimerkin että evenkilaulun n:o 6 perustana, vaikka kummassakin moodi on hieman erilainen: 1, 2, 3,4 vs. $4,1,2,3$.

Kuten notaatiosta näkyy, teksti ei ole puhtaasti kahdeksantavuinen, vaikka nousuja on kahdeksan, sillä jälkisäkeen viimeinen runojalka jää usein vajaaksi. Toisaalta melodia antaisi mahdollisuuden kahdeksantavuisuuden toteutua, minkä vuoksi tällä sävelmällä voi laulaa Kalevalan kannesta kanteen. Käytössäni oleva siperialainen aineisto on liian niukka, mutta uskaltaudun esittämään ensimmäinen hypoteesini, jonka testaaminen tullee aikanaan mahdolliseksi: tunguusien perinteessä kahdeksantavuisuutta lähentyvä syllabinen mitta liittyy laulutarinoihin, joissa tarinan kertoja esittää sankarin puheosuudet laulamalla. Käyttämällä 8-painoista runomittaa ja melodista ilmaisukeinoa, kertoja painottaa tarinan keskushenkilön asemaa ja erottaa tämän teot tarinan kaikesta muusta toiminnasta. Melodia rakentuu esi- ja jälkisäkeen miltei varioimattomalle toistolle. Näiden kahden säkeen väliin sijoittuu niin ikään liki muuttumattomana toistuva kertosäe.

Nanaiden keskuudesta on tallennettu myös matkalauluja, joista esimerkki 9 kuvailee kauniin solan läpi kulkevan ajatuksia ${ }^{19}$. Laulu pohjautuu nelisävelikölle $d^{l} e^{l} g^{l} a^{l}$, joten moodi käyttänee $r e$-pentatoniikan asteita $1,2,3$ ja 4 eli $d o, r e, m i, f a$. Sen kolmesta säetyypistä $A$ ja $B$ ovat komplementaarisia, $C$ on kadensoiva. Laulaja painottaa ensisäkeen jälkeen joka neljättä iskuosaa, mikä antaa sävelmäsäkeille $A$ ja $B$ selkeän hahmon:

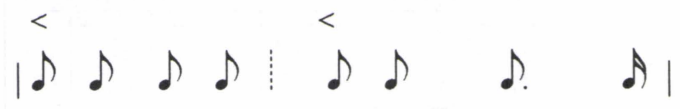

Sävelmässä on lisäksi monille tunguusilauluille tyypillinen ominaisuus, joka paljastuu mainiosti esimerkin viimeisellä rivillä: vaikka teksti ei näy seuraavan erityistä sääntöä, pohjalla on kahdeksantavuinen ja nelijalkainen mittasysteemi. Laulaja voi täytää jalan kokonaan tai - jos sana päättyy vokaaliin - käsitellä vokaalia pitkänä ja täyttää sillä koko jalan. Asiaa voi havainnollistaa kuviolla, jonka näennäisen tyhjiksi jäävissä laskuissa (0) vaikuttaa sama vokaali kuin jalan nousussa $(+)$. Ensin on nuottiesimerkin 9 alin rivi, sitten muutamia muita:

\begin{tabular}{|c|c|c|c|c|}
\hline Kaava: & + & + & + & + \\
\hline Säe: & $\begin{array}{l}\text { bai - kan } \\
\text { nih -- to } \\
\text { nik-- ke } \\
\text { šen -- de } \\
\text { ðau-- van }\end{array}$ & $\begin{array}{l}\text { dö --- lö } \\
\text { lum -- be } \\
\text { ðau - va-ni} \\
\text { ho -------- } \\
\text { бo -------- }\end{array}$ & $\begin{array}{l}z a-r a \\
j o ̈--z \ddot{o} \\
\text { šei-je } \\
\text { jän-de } \\
p^{\prime} a t-t i\end{array}$ & $\begin{array}{l}\text { sel --- din } \\
\text { se --- } n i \\
\text { če ---- } n i \\
\text { le --- } n i \\
\text { de ---- } i\end{array}$ \\
\hline
\end{tabular}




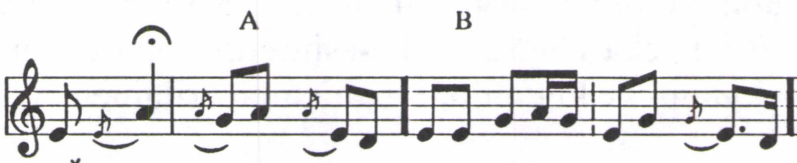

C
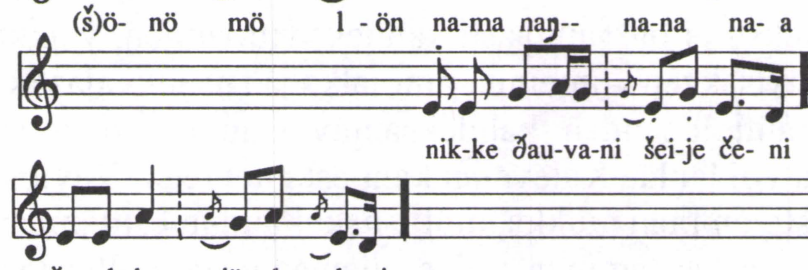

nik-ke ðau-va-ni šei-je če- ni

క̌n-de ho jän-de le-ni

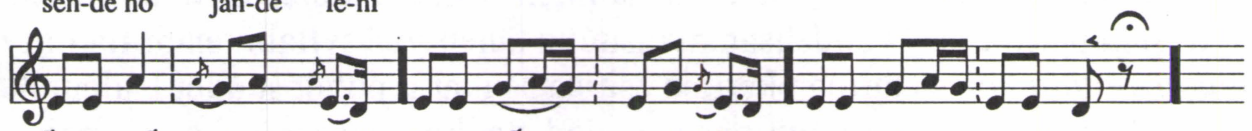

ðau-van-ðo p'at-ti de-i lau-van-ðo--- ma-la l'e-ni um-me ho-- wen-den-de

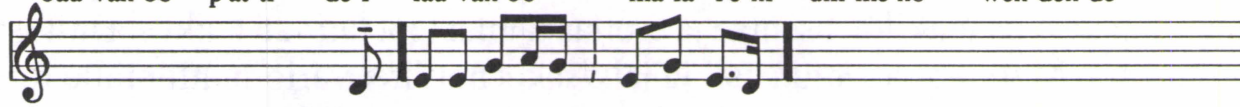

na mo-dan šav-va-ni mor-an he-e
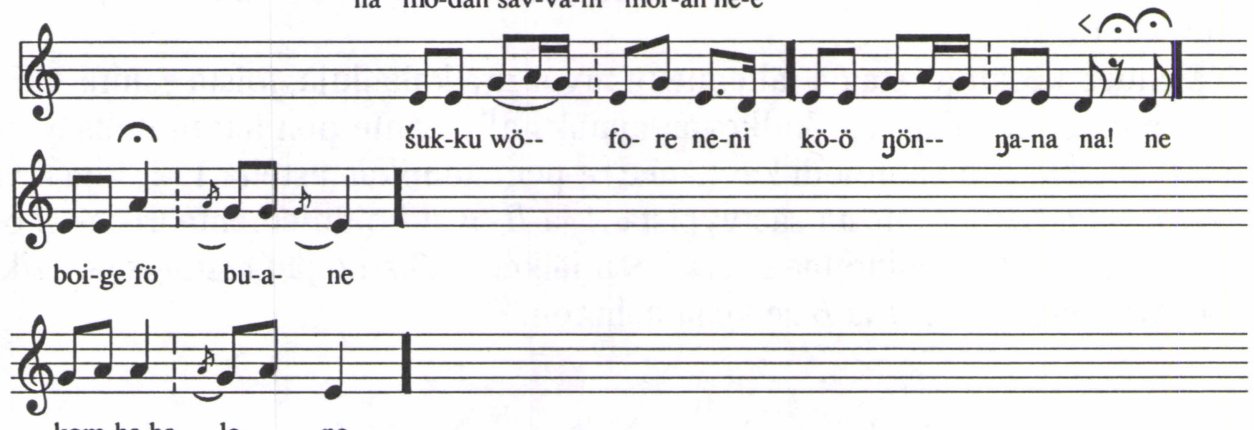

kom-ba ba le- ne

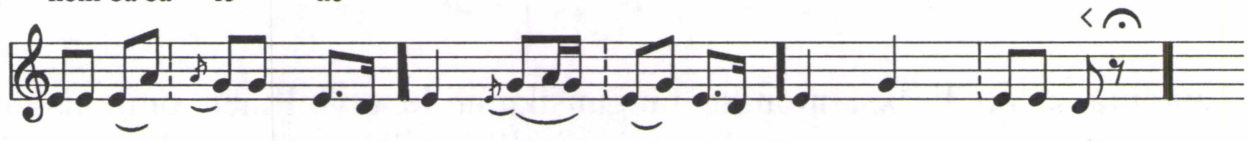

bla-ha-re bu-a- ne-e la- hay_ dö- ne-ni gö döy ña-na-na
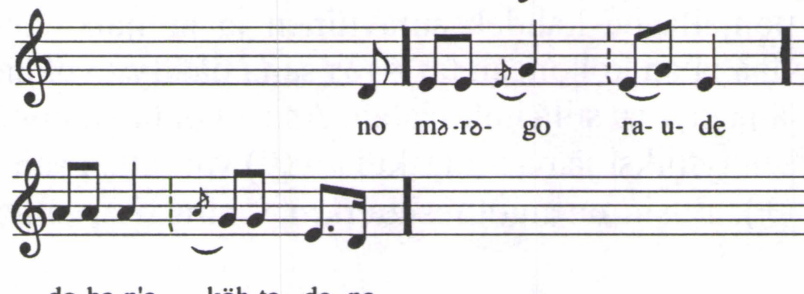

do-be-n'e köh-te- de-ne

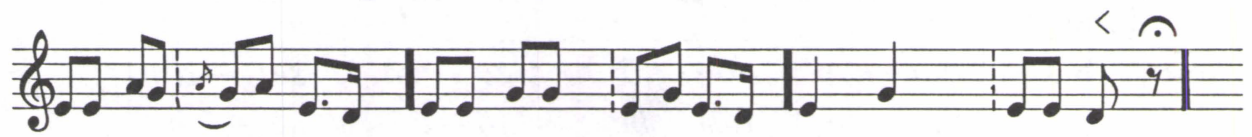

bai-kan dö-lö za-ra sel-din nih-tə, lum-be jö-zö se-ni ko- naך ja-na-na'

Nuottiesimerkki 9**. Nanaiden lyyrinen matkalaulu solan läpi kulkemisesta. (Ä̈̈nite: MSS II, 44.) 
Edellä esitetyn perusteella voidaan sanoa, että Siperian tunguuseilta ei taida juuri löytyä oktosyllabisen pohjakaavan selkeää käyttöä. Tyyneltä valtamereltä Keski-Siperiaan on kuitenkin viitteitä siitä, että tunguusit ovat soveltaneet nelipainoisuutta. Lisäksi on viitteitä siihen, että kahdeksantavuisuus on todellinen pohjakaava, vaikka tätä ei jokaisesta säkeestä huomaa, mihin päätelmään mm. esimerkki 9 antaa aiheen. Pohjakaavan musiikillisella käsittelyllä on tällaisenaankin paralleeleja itämerensuomalaisella alueella.

\section{A.5. Turkkilaiset}

Turkkilaiset kansat ovat protoaltailaisten jälkeläisiä ja mongolikansojen kielisukulaisia. Oheisessa laatikossa on mainittu joitakin turkkilaisia kansoja.

Tšuvaššit:

Eteläturkkilaiset:

Keskiturkkilaiset:

Itäturkkilaiset:

Pohjoisturkkilaiset:
- tšuvaššit (Volgalla)

- turkkilaiset (osmanit), turkmeenit, azerit, Balkanin turkkilaiset

- kiptšakit, tataarit, baškiirit, kalpaakit, kazakit

- uzbekit, uiguurit

- tofalarit (=tuvat), karagassit, jakuutit (= sahat), dolgaanit, šoorit, kirgiisit, oirootit (=altailaiset), Tšulymin tataarit

Toisin kuin useimmat mongoliheimot turkkilaiset kansat ovat säilyttäneet monia esihistoriallisia perinteitä, sillä niistä useimmilla ei ole ollut samalla tavalla välittömiä yhteyksiä Intian ja Kiinan korkeakulttuureihin kuin mongoleilla. Tässä kirjoituksessa ohitan tyydyttävän tiedon puuttuessa mongolien (siis mongolien, burjaattien, kalmukkien ja oirattien) lauluston. Siihen tulisi kuitenkin voida perehtyä, sillä turkkilaisten kansojen kulttuureissa kahdeksantavuisen pohjakaavan käyttö on hämmästyttävän vahva. Turkin valtiossa asuvien turkkilaisten kulttuuri on mitä erilaisimpien paikalliskulttuurien sulautumaa, sillä ennen turkkilaisten tuloa Vähään Aasiaan siellä oli vuosituhannet asunut sellaisia vahvoja väestöjä kuten kurdeja, kreikkalaisia, lyydialaisia, myysialaisia ja kaarialaisia tai myöhempiä tulokkaita kuten galatalaisia eli kelttejä.

Osmanien kirjavan metriikan joukossa on myös kahdeksantavuisuutta, mutta siihen en sen monimutkaisen olemuksen vuoksi puutu, sillä osmanit muuttuivat nopeasti korkakulttuuriksi. Myös tšuvaššien metriikka jää hämäräksi ja sen tarkistaminen tuonnemmaksi, vaikka asian selvittely on kiinnostava senkin vuoksi, että tšuvaššien kulttuuri on aasianturkkilaisen ja marilaisen aineksen monimutkainen seos. 
Eteläturkkilaisten azerien kulttuuriin on kuulunut eeppinen $K o ̈ r o g ̆ l u=K u$ roğlu = Kuruğli, jonka ovat tunteneet myös mm. uzbekit, kazahit, kalpaakit, turkmeenit ja osmanit. Azerien yhteiskunnassa Köroğlu-sykliä ovat esittäneet ammattimaiset $a$ šygit, jotka ovat säestäneet itseään pitkäkaulaisella $s a z$-luutulla. Esityksille on luonteenomaista, että ašygit tarinoivat muutoin paitsi esittäessään sankarien dialogit ja paikoin myös keskeisimmät episodit: ne kaikki on lausuttu laulaen. ${ }^{20}$ Tässä on paralleeli Siperian tunguusikansojen laulusaduille ja -tarinoille. Nuottiesimerkissä 10 on azerilaista Köroğlua, jossa on selkeästi oktosyllabinen pohjakaava:

$$
\begin{aligned}
& \text { A-la qöz-lü } \\
& \text { Ü-zün män-dän } \\
& \text { ni-qar za-nym } \\
& \text { Sä-nä gur-ban } \\
& \text { Ü-zün män-dän }
\end{aligned}
$$

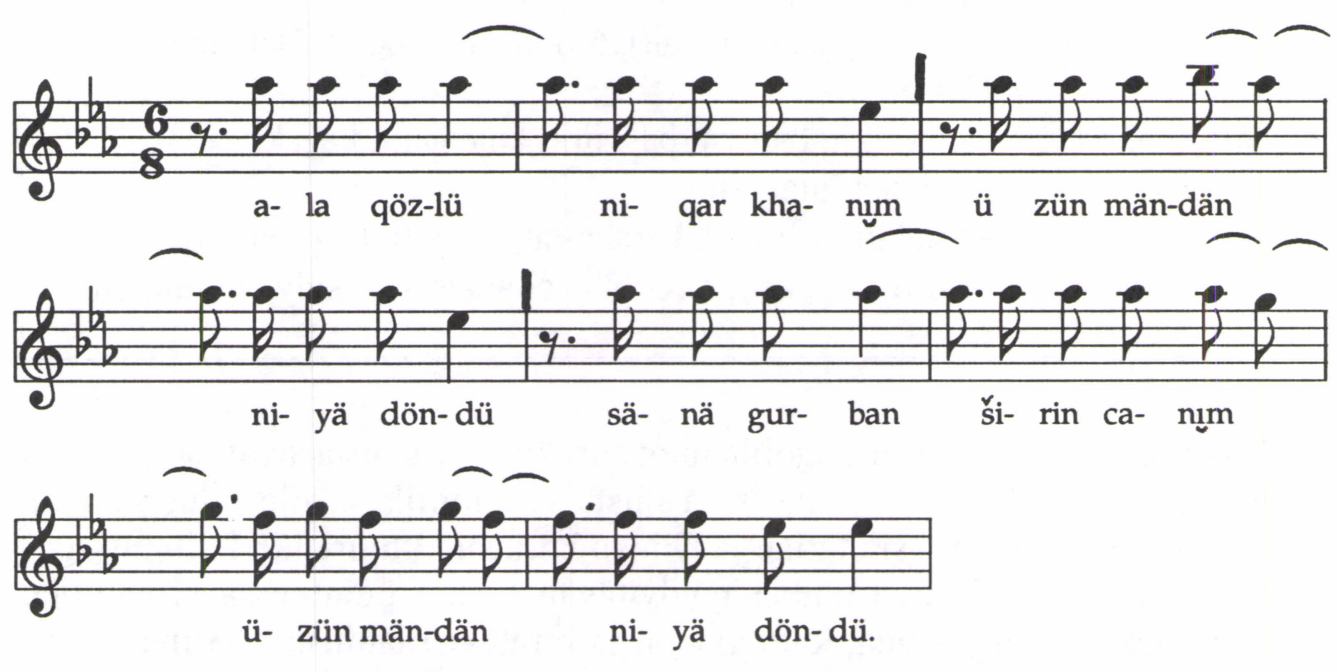

Nuottiesimerkki 10. Azerbaidžanilainen eeppinen laulu, Gözeleme köroğlu. (Nuotinnos: Mamedov 1984, 39, esimerkki 11.)

Musiikin iteratiivinen rakenne perustuu yhden tekstisäkeen mittaisen melodiasäkeen toistolle. Tässä näytteessä esiintyy kuitenkin jo orastavaa säkeistöajattelua, sillä suurmuoto koostuu 4 melodiasäkeen muodostamien säkeistöjen toistosta. Säkeistöjen muodostaminen ei kuitenkaan ole kuulunut vanhaan turkkilaiseen ajatteluun sen kummemmin kuin itämerensuomalaiseenkaan. Melodian kaari on laskeva, metri on $6 / 8$ ja moodin asteikkona on suuriterssinen pentakordi: $b^{2} a s^{2} g^{2} f^{2} e s^{2}$ eli so fa mi re do.

Toistaiseksi en ole löytänyt yhtään sellaista keski- tai itäturkkilaista melodialähdettä, jossa kahdeksantavuisuutta esiintyisi. Arvailen kuitenkin sitä läh- 
teiden lisääntyessä löytyvän. Toistaiseksihan äänilevyillä ja tutkimuksissa huomio on pääosin keskittynyt turkkilaisten kansojen taidemusiikkiin. Voin vain olettaa, että kahdeksantavuinen laulu liittyy edellä mainittuun yleisturkkilaiseen epiikkaan myös itäturkkilaisissa kulttuureissa. Varmaa on sen sijaan se, että kahdeksantavuinen metri on mitä tavallisin koko pohjoisturkkilaisella kulttuurialueella.

Tofat eli tuvat ${ }^{21}$, joiden omakielinen nimitys on tuba ja jotka tsaarinaikaisen käytänteen mukaan tunnetaan myös nimellä karakaš, asuvat Itä-Sajanin pohjoispuolisissa metsissä. He ovat tunnettuja kaksiäänisestä yläsävellaulusta, jota esitetään muidenkin altailaisten sekä myös mongolien, baškiirien ja hakassien keskuudessa $^{22}$. Niin monimutkaista ja varioivaa kuin tämä laulu onkin, sen teksti rakentuu säännölliselle kahdeksantavuiselle mittasysteemille, mikä voidaan nähdä $\mathrm{mm}$. nuottiesimerkistä 11 . Nuottiesimerkissä mittaan sidottujen esisäkeiden tekstinä on ${ }^{23}$ :

$\begin{array}{ll}\text { A-vam bi-le } & \text { a-čam y̌̌-kaš } \\ \text { a-my-ral-dyg } & \text { čü-vem-ne čok. } \\ \text { A-zy-rap kaan } & \text { ma-lym yš-kaš } \\ \text { a-myr to-dug } & \text { čü-vem-ne čok. }\end{array}$

Esimerkin 11 melodia pohjautuu teksinkäsittelyssä re-pentatoniselle ainekselle, jossa ovat mukana asteet $1,2,3,4,5,1\left(1\right.$ eli $\left.d o=a_{1}\right)$. Laulaja toteuttaa luonnonsäveljakson vaihtovuoroisesti asteiden 5 ja 1 ( $g$ ja $a$ ) varassa.

Isosyllabisuuden käsittelyn moninaisuutta voi kuvata tofalarien muullakin musiikilla. Esimerkin 12 lyyrinen teksti kuuluu: 'Tulin noilta seuduilta, auttajia etsimään; tulin sieltä, laulamme kaikki yhdessä"'24.

Dää lä jer-dän ke-li-rim-dä / däm-nä-džein daž́ $\quad$ kel-dim läi-naah 16

o-l(uj) džer-dän ge-li-rim-dä/ oi-na-džein daəš $\mid$ kel-dim läi-naah 16

Laulussa ei ole säkeistöjä vaan iteroivana yksikkönä on 16 tekstitavua käsittävä säepari $a b a b \ldots a b$. Melodia pohjautuu $d o-s o$-pentakordille, jossa on suuri terssi, ja on tyylillisesti samanlainen kuin monet itämerensuomalaiset sävelmät. Tämänkin pohjalla uinuu tonaalisia funktioita.

Esimerkissä 12 ei liene kyse länsieurooppalaisen tonaalisuuden tunkeutumisesta venäläisten välittämänä lainana Sajanille sen kummemmin kuin se lienee lainaa itämerensuomalaisellakaan taholla. Luultavasti tässä on vanha traditio, joka on syntynyt musiikin sisäisistä ominaisuuksista. 

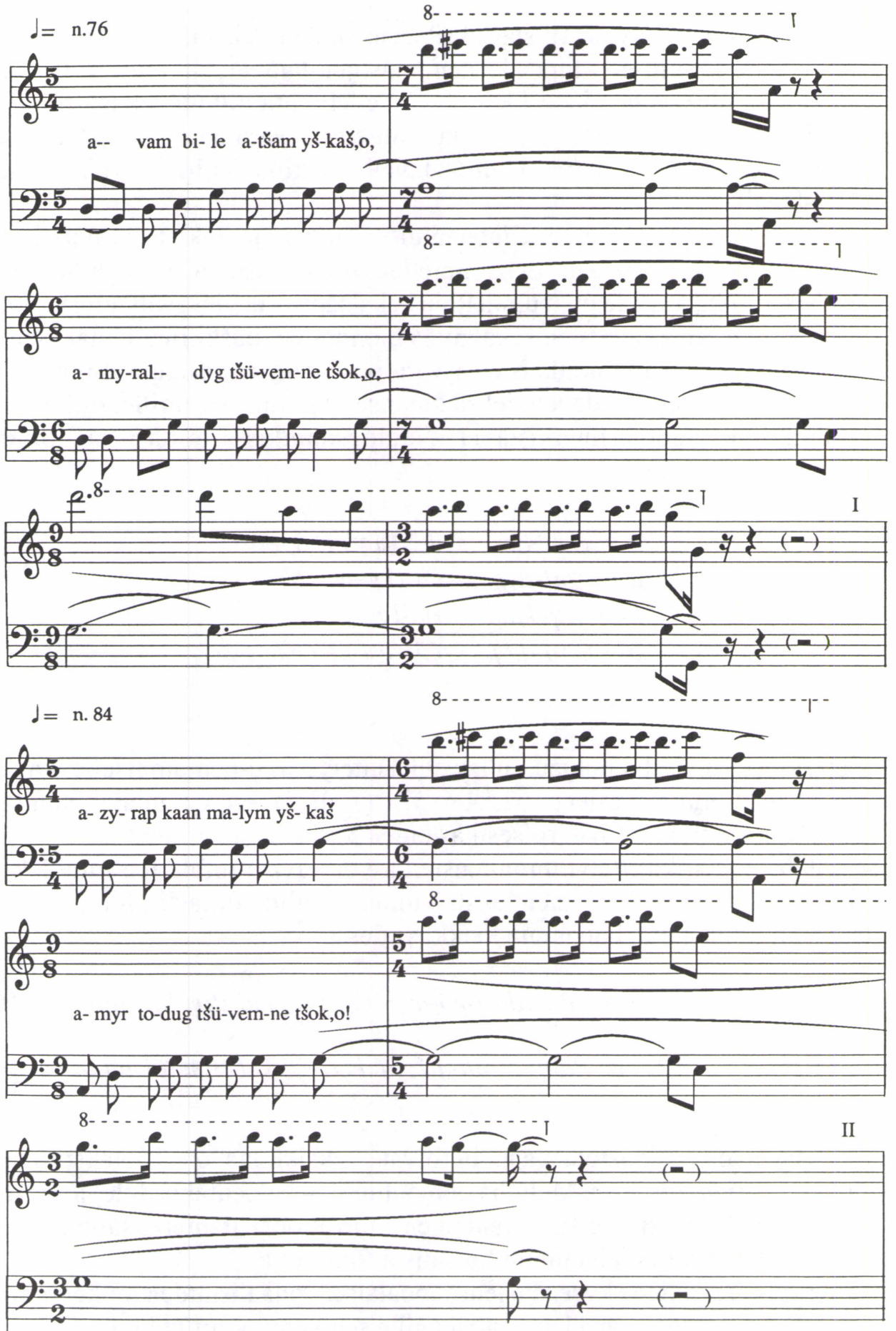

Nuottiesimerkki 11. Sygyt-tyylissä etenevä tofalainen (tuvalainen) yläsävelmelodia, joka koostuu metrisesti sidotusta tekstiosasta sekä vapaasta yläsävelimprovisaatiosta, joka muuttaa laulun kaksiääniseksi.(Nuotinnos: Aksenov 1964, n:o 71.) 
Aivan toisenlainen on lyyrinen Neidon laulu esimerkissä 13. Sen sävelmä koostuu säeparista, jolla laulaja käsittelee kahdeksantavuisia tekstisäkeitä ${ }^{25}$.

\begin{tabular}{|c|c|c|c|}
\hline$a a-d z ̌ y m ~ b i-l e$ & $\check{c} a r-l y p ~ \check{c} a-d a p$ & 8 & En voi olla poissa ystäväni luota \\
\hline ar-ty tur-hu & ba-ryp ča-dap & & en voi häntä jättää \\
\hline džim bi-le & čar-lyp ča-dap & & en voi olla poissa ystäväni luota \\
\hline$d z ̌ i k$ tur-hu & ba-ryp ča-dap & & en edes käväistä oven takana. \\
\hline
\end{tabular}

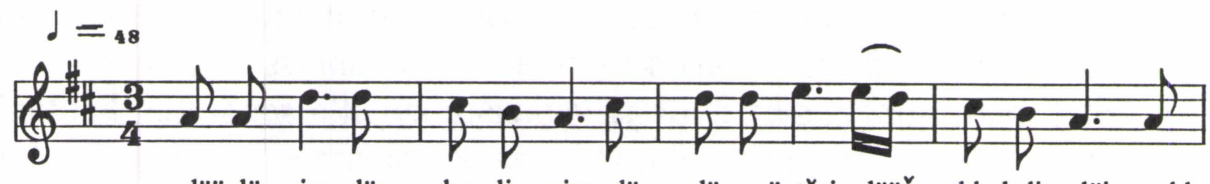
dää lä jer-dän ke- li- rim- dä, däm-nä tšein dääš khel-dim läi-naakh.

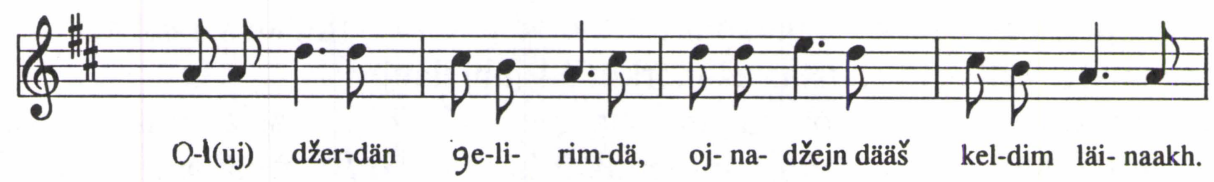

Nuottiesimerkki 12. Tofalarilainen sävelmä. (Nuotinnos: Stojanov 1980, n:o 5.)

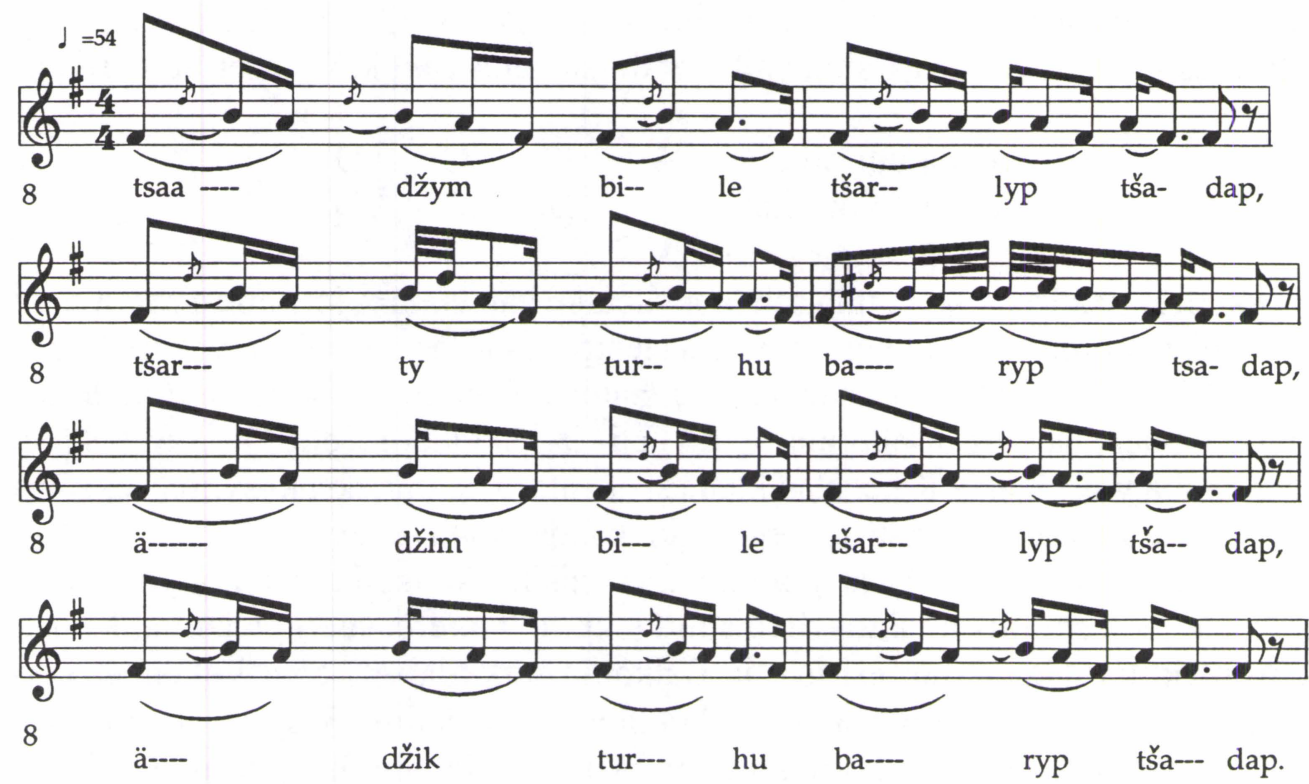

Nuottiesimerkki 13. Neidon rakkauslaulu tofalarien alueelta. (Nuotinnos: Stojanov 1980, n:o 1.) 
Melodian rakennusaineina on $m i$-pentatonisen asteikon alaosasta koottu tetratoninen moodi, jonka ylin ( $\mathrm{d} 2=\mathrm{fa})$ sävel toimii koruna. Asteet ovat 1,2 , 3,4 eli $d o-f a$. Pentatoniikka saattaa hyvinkin olla lainaa ajalta, jolloin (Euroopassakin keskiajan lopulla valtaa pitäneet) mongolit olivat asustaneet tofien alueilla. Tofien oktosyllabiselle mitalle pohjautuvat melodiat voivat olla erittäin monimutkaisia ${ }^{26}$, mutta tietyt piirteet ovat niille ominaisia aina: (1) laulaja käyttää vain muutamaa säveltä; (2) säkeen tai säeparin mittaista tekstiyksikköä vastaa säkeen tai säeparin mittainen melodiayksikkö; (3) sävelmässä esiintyy suhteellisen niukasti muuntelua.

Pohjoisturkkilaisen väestön pohjoisena kansana ovat jakuutit eli sahat, jotka tunkeutuivat nykyisille alueilleen etelästä vasta muutama vuosisata sitten, jolloin myös ensimmäiset venäläiset olivat valloittamassa samoja seutuja. Koska sahat ovat asuneet syrjäisillä ja vaikeakulkuisilla seuduilla, heidänkin vanhakantainen kulttuurinsa on säilynyt omaan aikaamme. Siihen on kuulunut täsmällistä kahdeksantavuista mittaa toteuttava laulutapa, joka ei ole sillä tavalla koristeellinen kuin paikoin tofilla, vaan on tyyliltään varsin itämerensuomalaista. Tällaista edustaa esimerkin 14 juhlalaulu ${ }^{27}$.

Esimerkin 14 melodia on tiukan syllabinen. Moodi on ensialkuun trikordi $(f$ $g a$ ), mutta laajenee pian ylöspäin tetrakordiksi $(f g a h)$, mikä antaa moodille doorisen latauksen. Etelämpänä asuvien sukulaisten pentatoninen piirteistö on jakuuteilla kordinen, mitä tämäkin esimerkki osoittaa. Sävelmä on jälleen tyyliltään itämerensuomalaisen virren kaltainen. Yhtenä erona on se, että kahdeksantavuiseen säkeeseen saattaa tulla lisätavu myös 2. tai 3. runojalkaan, mikä näkyy nuottiesimerkissä 14 kuudestoistaosina. Vaikka melodia koostuu viidestä erilaisesta motiivista (säerakenteista A, B, C, D, E), laulu pysyy jatkuvasti kaksisäkeisenä, sillä vaihtoehdoista aina vain kaksi asettuu pariksi:

$\begin{array}{llllll}\text { esisäkeenä voi olla: } & \text { A } & \text { B } & \text { C } & \text { D } & \\ \text { jälkisäkeenä voi olla: } & & \text { B } & \text { C } & \text { D } & \text { E }\end{array}$

Esimerkissä 15 on jakuuttilaisen juomalaulun katkelma ${ }^{28}$, jota miesryhmä esitti solistin ja kuoron vuorotteluna tasaisessa tempossa ja täsmällisessä rytmissä käyttämällä kolmea perättäistä säveltä $d, e, f$. Samanlainen responsoria on ollut tuttua myös itämerensuomalaiselle juhla-, rituaali- ja leikkiperinteelle. Vaikka tälläkin sävelmällä voisi laulaa Kalevalan kannesta kanteen, avoimeksi kysymykseksi jää se, onko esimerkin 15 teksti seitsen- vaiko kahdeksantavuinen.

Ainakin etelä-, keski- ja pohjoisturkkilaisilta kansoilta on löytynyt yhtä selkeää ja täsmällistä oktosyllabisuutta kuin itämerensuomalaisilta. Monet kansat (kuten tšuvaššien esi-isät ja Balkanin turkkilaiset) ovat kokeneet voimakkaita kulttuurimuutoksia, mutta kuten mm. osmaninturkkilaiset osoittavat, kahdeksantavuisuutta voi kuitenkin löytyä oman aikammekin perinteistä. Tältä kannalta katsottuna on odotettavissa, että sitä löytyy myös pääosin LounaisKiinassa eläviltä uiguureilta. 

A
B
C
D
$\mathrm{E}$
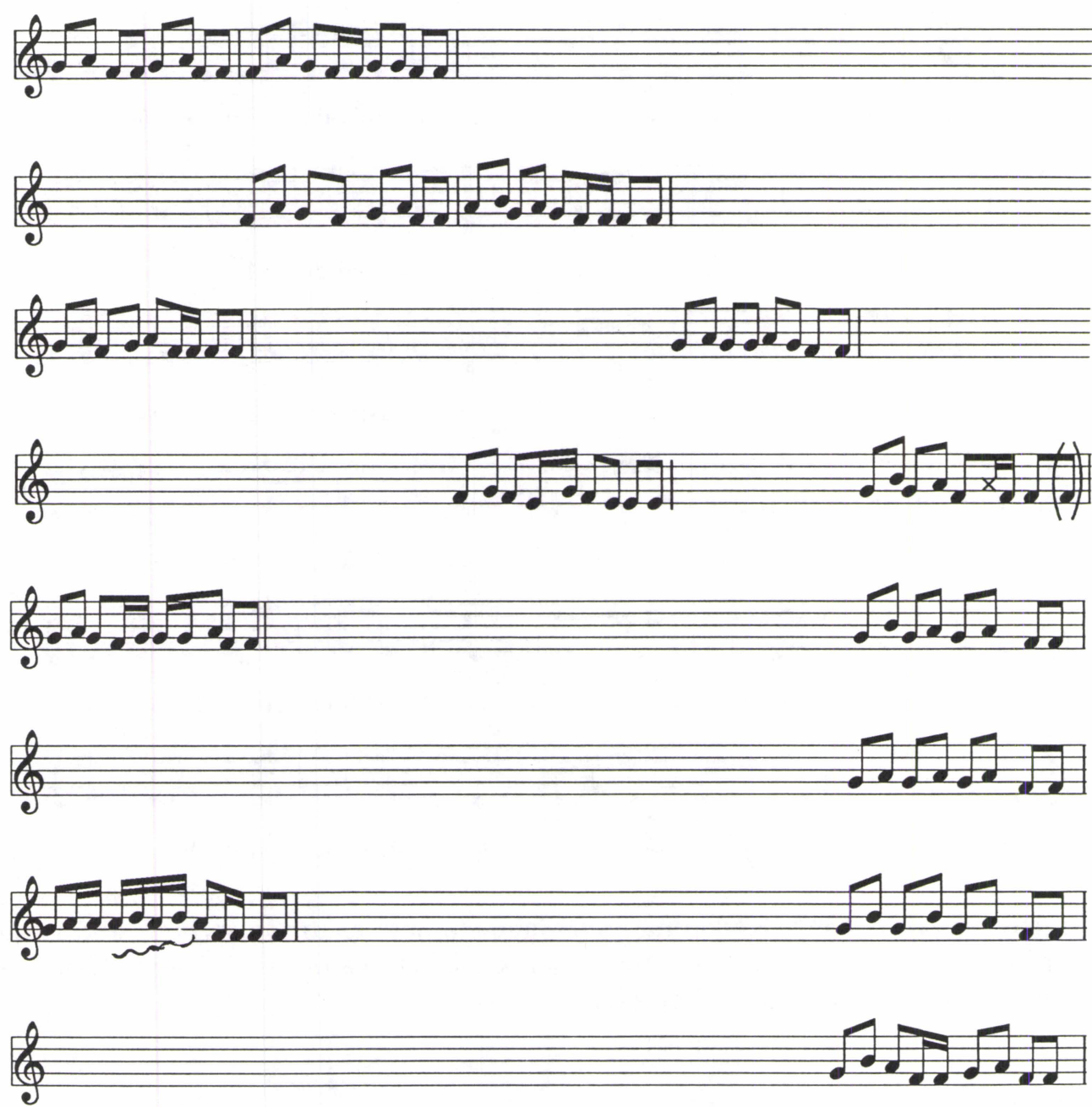

Nuottiesimerkki 14**. Katkelma vuonna 1891 syntyneen Sergei Zverevin solistisesti esittämää juhlanavauslaulua, joka kuuluu jakuuttien perinteeseen. (Lähdeäänite: YMF I, 2.) 
solo

kuoro

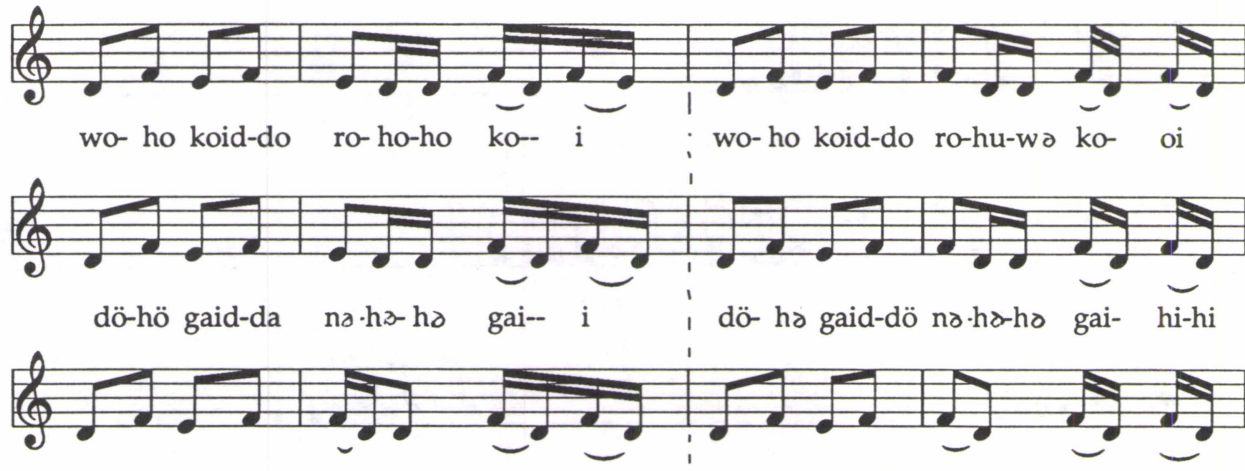

mi- nä daid-dum bar-habs say-

' mi- nä daid-dum ba--

ra-- ha--

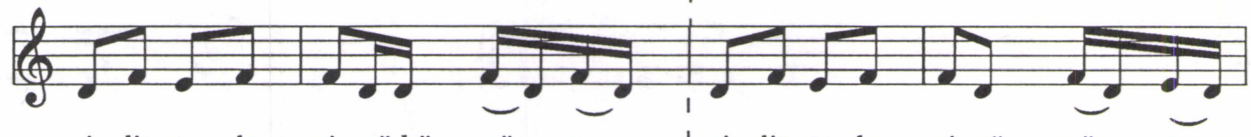

si- lit- te- le si- nä-hä nän-- n $\quad$ si- lit- te- le si-nä- nä-- $n$

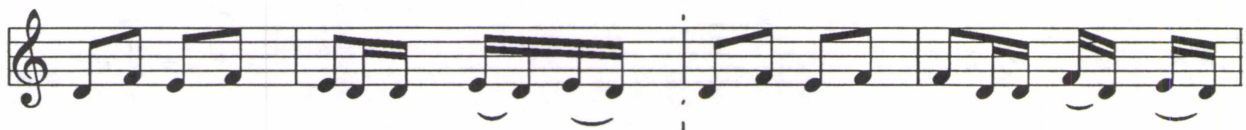

sie--dä reid-dir be-jä-hä lä-- äh $\quad$ sie- dä reid-dir be-jä-hä lä-- ä

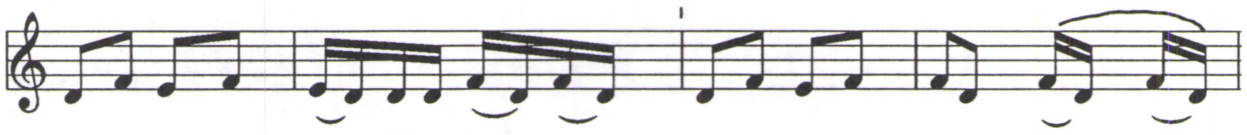

si- rin doid-du myr-dy-hy gä-- är si- rin doid-du myr-dy-här

Nuottiesimerkki $15^{* *}$. Katkelma juomalaulusta, jota esitti miesryhmä solistin ja kuoron vuorolauluna. Äänite on Novosibirskin konservatorion arkistosta Kansanperinteen laitokseen saadulla kopiolla.

\section{Jakuuttien vaikutusta Keski-Siperiassa?}

Jakuutit ovat levittäytyneet laajalle alueelle keskisessä Ylä-Siperiassa Jenisein kummallakin puolella. Kiinnostavasti on kaksi ei-turkkilaista kansaa, joiden perinteessä saattaa ehkä näkyä jakuuttien taholta tullutta vaikutusta.

Evenkien (kuten muidenkin tunguusien) kulttuurista on ollut vaikea löytää kahdeksantavuisuuden ehdottoman säännöllistä toteutumaa. Sen vuoksi tuntuu oudolta, että on yksi eveeneihin liittyvä lähde ${ }^{29}$, jossa toteuma on likimain täydellinen. Kyse on erään eveenien kulttuurista suuresti kiinnostuneen venäläisen miehen esittämästä laulusta nimeltään 'Juokseva poropaimen' (nuottiesimerkki 16).

Esimerkissä 16 laulutyyli vaikuttaa aidolta ja sävelmän rakenne on tyylinmukainen ja edellisen sävelmän lailla se pohjautuu trikordille: $f g a$. Kuitenkin 
oktosyllabisuuden liki ehdoton noudattaminen oudoksuttaa. Onkin mahdollista, että tässä nimenomaisessa äänitteessä on naapureilta, siis jakuuteilta, omaksuttua lainaa eveenilaulustossa. Sävelmä on kiintoisa, sillä se muistuttaa laatokankarjalaista sävelmää, jonka teksti alkaa pyyntivirtenä ja jatkuu karhulle kohdistettuna loitsuna ${ }^{30}$ (esimerkki 17). Samankaltaisuuden selittäjänä itämerensuomalaiseen kulttuuriin on kuitenkin tyyliainesten samuus, ei sukulaissuhde, kun taas geneettinen lainasuhde vaikuttaa mahdolliselta Siperiassa.

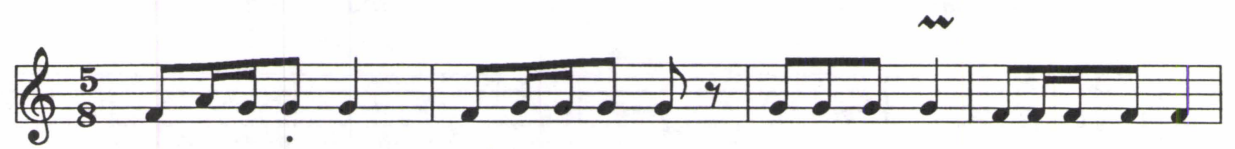

nai ja- vo- ran-na
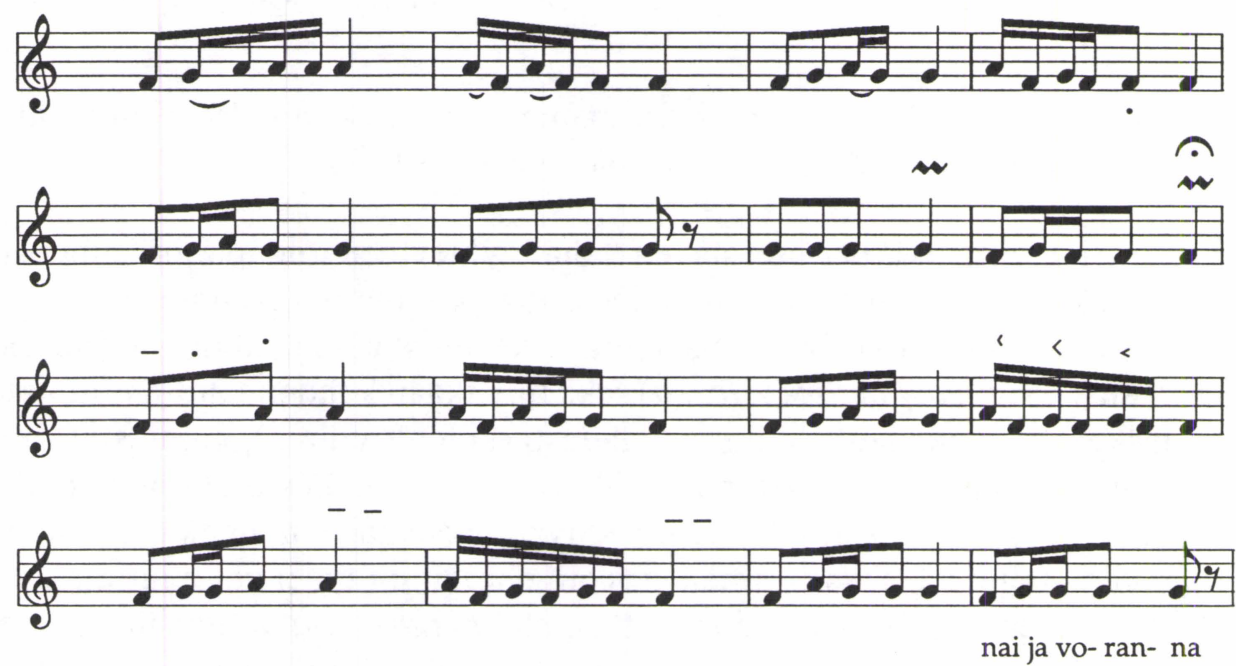

Nuottiesimerkki 16**. 'Juokseva poropaimen', eveeniläinen sävelmä. (Äänite: YMF I, 7.)

Jukagiireja asui vielä 1600-luvulla Lenalta Anadyr-joelle, siis Keski-Siperiasta Itä-Siperiaan, mutta tätä nykyä enää Indigirkan ja Kolyman seuduilla. Jugakiirit ovatkin enää vain muutamia satoja ihmisiä käsittävä kansa, joka on perinteiseti määritetty paleosiperialaiseksi. Hiljan on kuitenkin alkanut vahvistua käsitys, jonka mukaan protourali ja protojukagiiri olisivat olleet jääkauden jälkeisen jakson alkupuolella puhutun yhteisen emäkielen kaksi haarautumaa ja näin jukagiiri olisi suomenkin kaukainen sukukieli. 


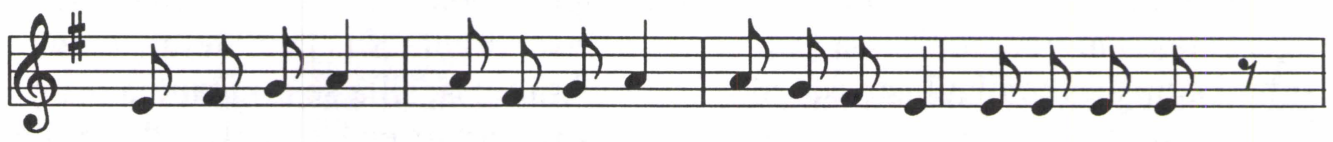

koi- ra- ni ke- rä- nä vie-ri, koi-ra-ni ke- rä- nä vie-ri

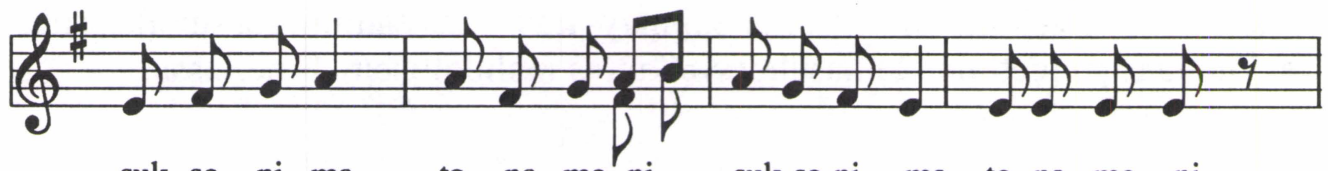

suk- se- ni ma-- to- na me-ni, suk-se-ni ma- to- na me- ni.

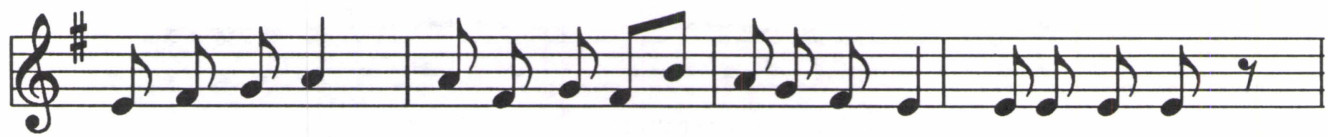

oh- to- sen pe-- sän o-- vil-la---, oh-to-sen pe- sän o- vil- la.

Nuottiesimerkki 17. Armas Launiin Suistamon Terovaarassa v. 1905 fonografoiman karhuvirren ja karjaloitsun yhdistelmä. (KRS n:o 173.)

Jukagiirien musiikkiperinteestä en tähän yhteyteen ole paljon aineistoa saanut. Joukossa on kiintoisa laulu, joka saattaa kuulua oktosyllabiseen perinteeseen (nuottiesimerkki 18) ${ }^{31}$. Sävelmä koostuu kahden tahdin mittaisesta esisäkeestä (turuva urgin jokko dəkka) sekä niin ikään kahden tahdin mittaisesta jälkisäkeestä, jonka laulaja toistaa kahdesti (kuten rivillä 3), kolmasti (kuten laulun alussa) tai neljästi (kuten rivillä 5). Melodia käyttää vain kolmea peräkkäistä säveltä ja lauluteksti näyttää koostuvan leksikaalisen aineksen ja täytetavujen yhdistelmistä. Tässä törmää taas ongelmiin, joihin ei voi puuttua ilman jukagiirin kielen taitajan apua. Jos olettaa, että kiagaja ajajaj edustaa täyteainesta, leksikaalista osaa hallitseva mitta olisi milloin nelilaskuinen, milloin kolmilaskuinen (= seitsentavuinen niin, että tavuista kolmas jatkuu [---] myös runojalan laskuun):

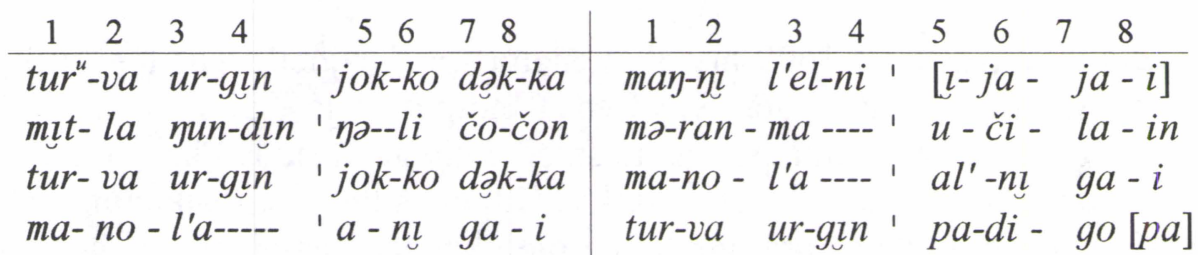

Laulu kuvaa jakuuttilaista poropaimenta maalailevasti ja lyyrisesti, mutta se herättää kysymyksiä, joihin en tässä kykene vastaamaan. Onko laulussa kahdeksantavuista kaavaa ja jos on, onko se jukagiirien vanhaa kulttuuria? Jospa kaava edustaa jakuuttien oktosyllabisen mitan suhteellisen myöhäistä lainaa? Voisiko venäläisten tšastuškalla olla siihen osuutta? Asia on pakko jättää tähän. 

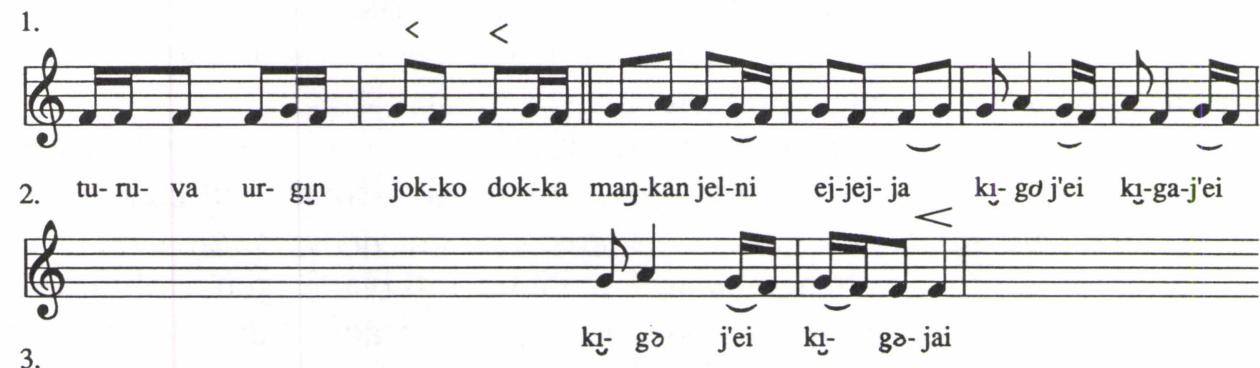

3.

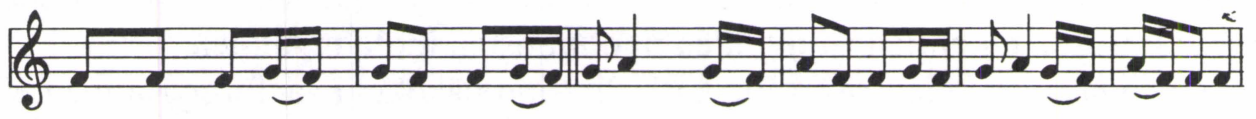

4. mit- la kun-dı ñ na-li jo- jo mar-ran- ma u- či- lá- in', kl- ga-jai kı- ga-jai

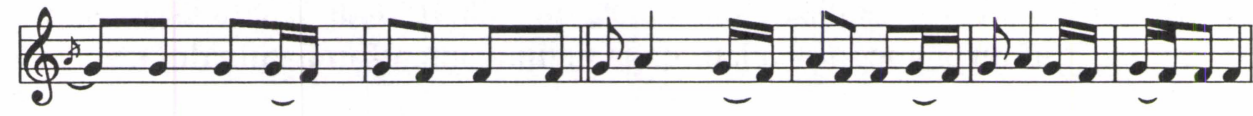

5. tur- va ur- gun jok-ko dok- ka man-nul- l'a al'-ni ga-i kl-gojai ka- ga-jai

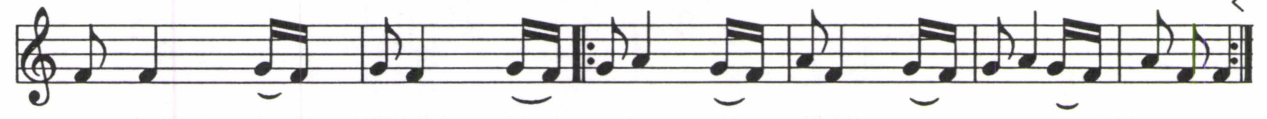

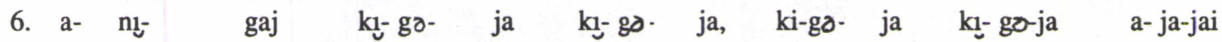

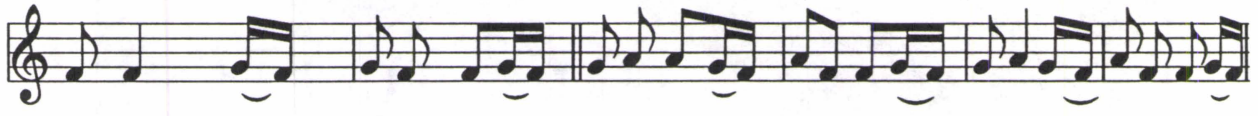

7. a- no-- l'a a- nı- ga- i- tur-va ur-gun pa-di-go (pa) kl-go-ja a- ja- ja-i

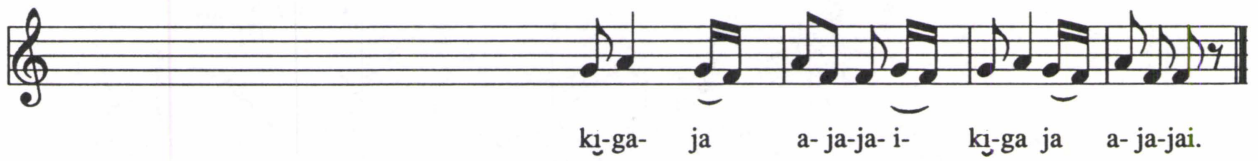

Nuottiesimerkki 18**. Jukagiiriläinen laulu nimeltään "Jakuutti poropaimenena". (Äänite: MSS III:62.)

\section{Samojedit}

Kantasamojedit asuivat vielä pari vuosituhatta sitten Obin latvoilla ja Jenisein keskijuoksulla. Tuolloin heidän naapureinaan oli mm. kantaturkkilaisia, -tunguusilaisia ja -ugrilaisia heimoja (kartta 3 ). Heistä osa alkoi muuttaa pohjoiseen osan jäädessä ikivanhoille asuinsijoille, joilla myös uralilainen kantaväestö oli arvelun mukaan elänyt yli kuusi vuosituhatta sitten. Eteläisistä heimoista nykyisin ovat olemassa vain selkupit, sillä matorit, koibaalit, kamassit ja karagassit (vrt. tofat) ovat sulautuneet naapureihinsa. Sen sijaan pohjoissamojedit eli nenetsit, enetsit ja Euraasian pohjoisin kansa, nganasanit, ovat vielä elossa. 
Samojedien laulun ymmärtäminen tutkijoiden piirissä tuli oikeastaan mahdolliseksi vasta noin 8 vuotta sitten, kun Juha Janhunen ${ }^{32}$ oli julkaissut tulkintansa metsänenetsien laryngaaliklusiilista. (Samainen klusiili on suomen kielessä mm. käskymuodon mene" lopussa. Käskymuoto oli kauan sitten ollut asussa *menek, mutta aikaa myöten lopussa ollut $k$ surkastui klusiiliksi. Sanommekin tämän muistona yhä $\mathrm{mm}$. menekkös siitä tai menes siitä!.) Janhusen oivalluksia alkoivat soveltaa nganasanin kieltä tutkiva Eugen Helimski ja nenetsien musiikkia tutkiva Jarkko $\mathrm{Niemi}^{33}$. Uusien lisäoivallusten seurauksena Niemi on saattanut $\mathrm{mm}$. arvioida perusteellisesti uudelleen sekä Donnerin että Lehtisalon tekemien äänitteiden nuotinnosten luotettavuuden ${ }^{34}$.

Seuraavassa esittelen ensin Eugen Helimskin näkökulmaa Taimyrin niemellä asuneiden nganasanien metrisiin systeemeihin ${ }^{35}$. Toisin kuin aiemmin oli luultu, nganasanien musiikissa vallitsee kaksi isosyllabista mittajärjestelmää, joista kolmijalkainen strukturoi allegorisia lauluja ja nelijalkainen šamaanilauluja:

$$
\begin{array}{ll}
\text { 3-jalkainen: } & +0 \leftarrow 0 \leftarrow 0 \\
\text { 4-jalkainen: } & +0 \leftarrow 0 \div 0 \leftarrow 0
\end{array}
$$

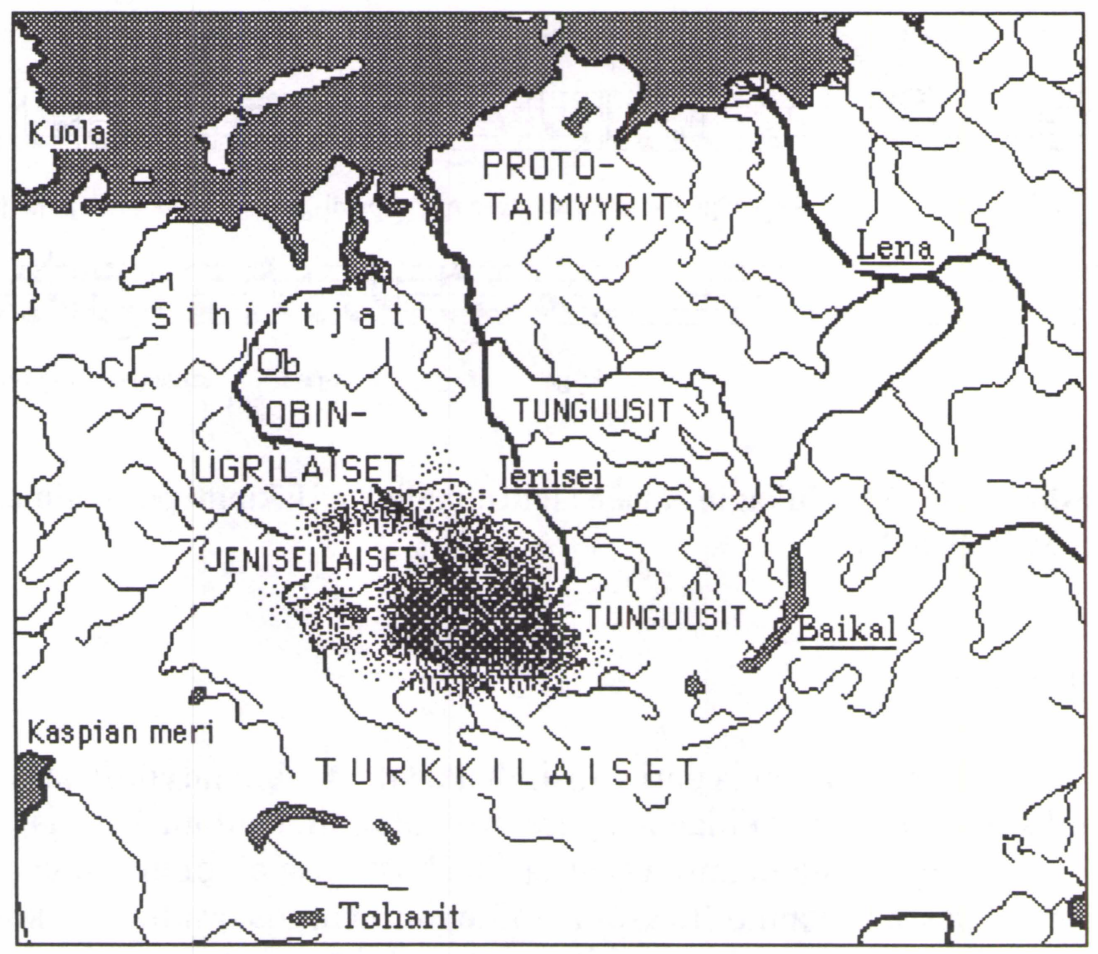

Kartta 3. Protosamojedit (tummennettu alue) ja heidän naapurinsa ajanlaskumme alkua edeltäneinä vuosisatoina Eugen Helimskiä mukaellen. Luoteessa olevat sihirtjat ovat monien alueella ennen samojedeja asuneiden vanhojen kansojen yhteisnimitys. Ne tunnetaan lähinnä van samojedien muinaisuutta kuvaavan epiikan kautta. 
Allegorinen laulu (kəjpəirśa) on perinnelaji, jolle on ominaista tekstin monitasoinen symboliikka, ja johon kuuluu rakkaus- ja juomalauluja sekä henkilökohtaisia lauluja. Laulut rakentuvat 6-tavuiselle mitalle hyvinkin monimutkaisella tavalla. Jotta lukija ymmärtää helpommin nganasanien metriikkaa, selostan lyhyesti Eugen Helimskiin ${ }^{36}$ nojautumalla ensin allegorista laulua.

Nganasanien allegoristen laulujen heksasyllabinen metriikka ei näy laulun pintatasolla, sillä mitta on muunnettu erikoiseksi laulukieleksi, johon on lisätty sekä ei-leksikaalisia tavuja (sekreemeitä) että normaalikielestä poikkeavaa allegorista sanastoa. Oheisessa laatikossa on esimerkki tästä. Laulajan mielessä on 6-tavuinen juuriteksti, jota kukaan ei koskaan kuule, sillä esittäjä muuntaa sen erityisella kəjĐəirśa-kielellä eteneväksi tekstiksi. Nganasanit ymmärtävät laulun transformoidun sisällön ja saavat kuulemastaan nautinnon, mutta tätä nykyä on tuskin ketään, joka osaa enää luoda uusia kəjĐəirśa-lauluja.

\begin{tabular}{|c|c|c|c|c|}
\hline JUURITEKSTI & \multicolumn{4}{|c|}{ LAULUTEKSTI } \\
\hline 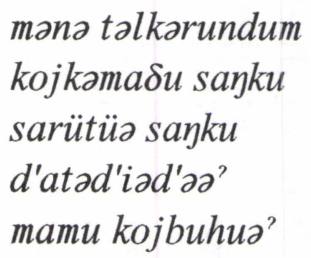 & $\begin{array}{l}\partial \\
\partial \\
\partial \\
\partial \\
\partial\end{array}$ & $\begin{array}{l}\text { awamawa } \\
\text { anantama } \\
\text { azhawa } \\
\text { anวawa } \\
\text { ahahawa }\end{array}$ & 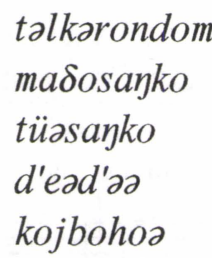 & 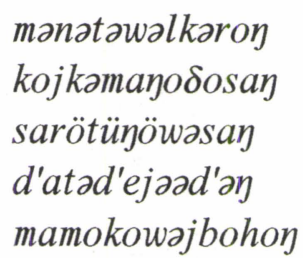 \\
\hline
\end{tabular}

Laatikon riveillä tekstin merkitys on seuraava: "minä ihmettelen: kirkonkelloin, sidotuin kelloin, taottu on maan vahvuus.". Ihmettelijänä on laulajan sisar. Helimskin mukaan jokaisella allegorisella laululla on oma avaimensa tai koodinsa, jonka avulla laulaja transformoi juuritekstin laulutekstiksi. Tässä tapauksessa avain näkyy oheisena kuviona, jossa $S$ tarkoittaa tavua ja sen vieressä oleva numero tavun järjestysnumeroa säkeessä $\left(S_{1}=\right.$ säkeen ensitavu ja $S_{6}=$ säkeen viimeinen tavu). Kuvion yläosaan on kuvattu juuritekstin säerakenne kuusine tavuineen.

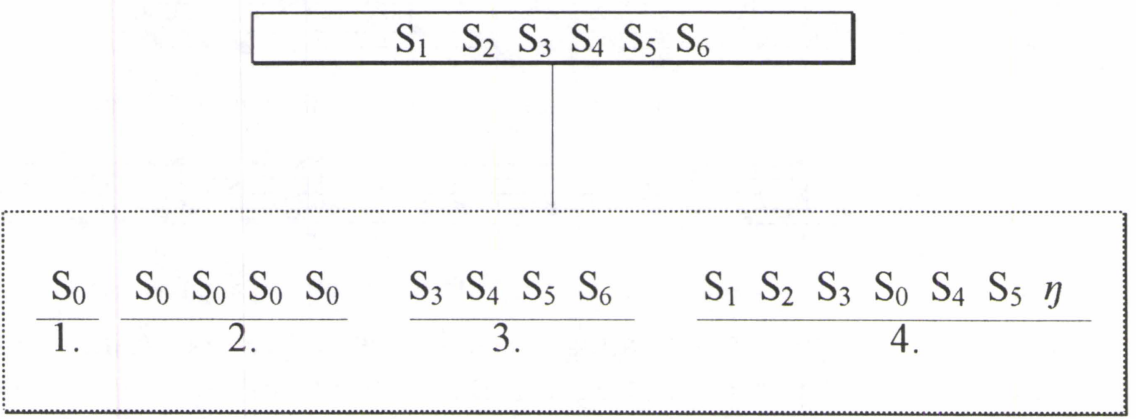


Kuvion alaosassa on lauletun tekstin rakenne, joka on samalla itse avain, sillä tavujärjestys on likipitäen sama jokaisessa säkeessä. Tämän laulun avaimessa $\mathrm{S}_{0}$ tarkoittaa tavua, joka ei kuulu juuritekstiin, mutta kuuluu laulettaessa. Laulu alkaa siis 0 -tavulla ja päättyy $n g$-äänteeseen $\eta$. Avain koostuu neljästä segmentistä. Segmentti 1. on yksi ainoa äänne, joka tässä laulussa on $\eta$ tai $m$. Myös segmentti 2. koostuu pelkistä nollatavuista $\left(\mathrm{S}_{0}\right)$, joita on neljä. Niillä ei ole leksikaalista merkitystä ja ne voivat olla esim. əwəməwə tai ənəntəmə. Juuriteksti ilmaantuu esiin vasta segmentissä 3., mutta silloinkin se alkaa juurisäkeen 3. tavulta $\left(\mathrm{S}_{3}-\mathrm{S}_{6}\right)$ kuten:

$$
\begin{array}{cccccccc}
t \ddot{u}-\partial-s a \eta-k o \\
3 & 4 & 5 & 6
\end{array} \text { tai } \begin{array}{cccc}
k o j-b o-h o-\partial . \\
3
\end{array}
$$

Viimeinen segmentti koostuu seitsemästä tavusta, joista yksi on nollatavu ja yksi on säkeenpäättävä $\eta$. Vasta tässä segmentissä kuulija tutustuu ensimmäisen kerran juuritekstin alkutavuihin, ja lisäksi saattaa tapahtua myös variaatiota, jos $\mathrm{S}_{0}$ ja $\mathrm{S}_{4}$ vaihtavat paikkoja säkeen keskellä:

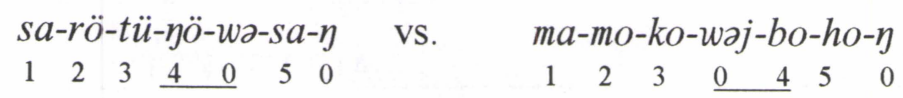

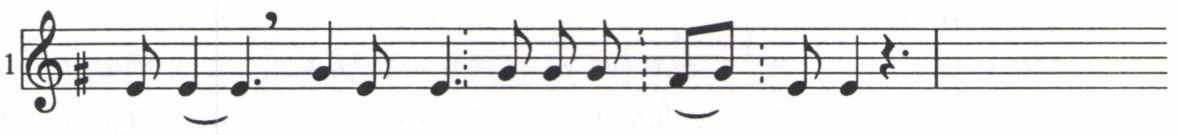

m- to um-um- yo na- hu-mə who mu-non

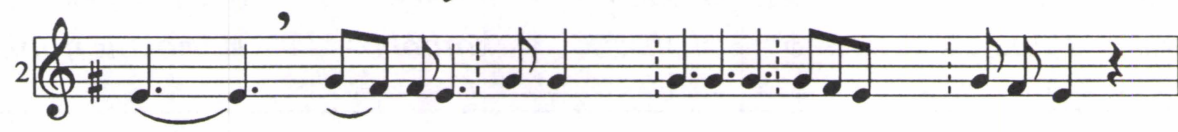

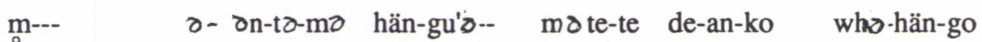

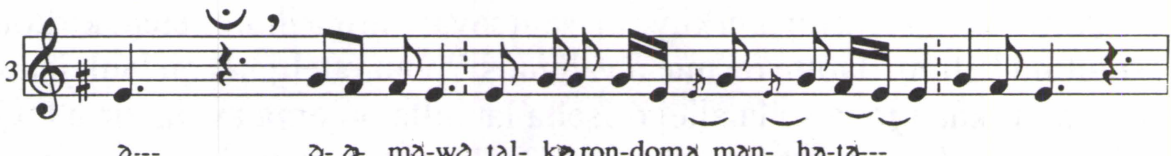

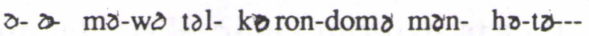

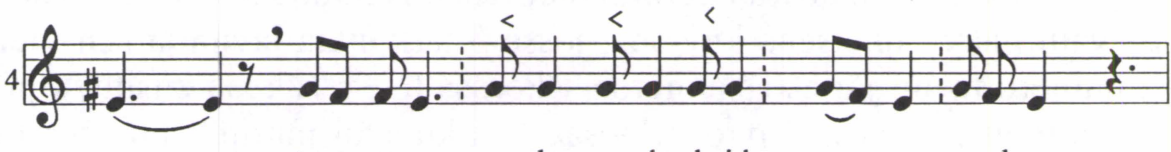

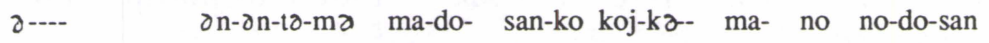

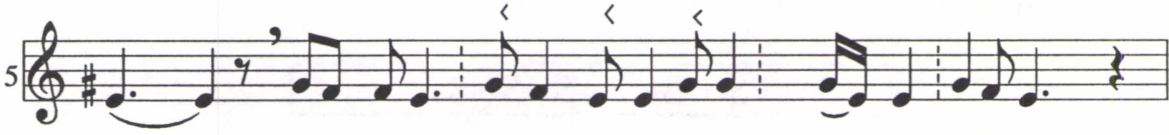

m--- o-nə-hə-wa tü- ö san-ko sa-rö tü-- nöw tün-ə-san

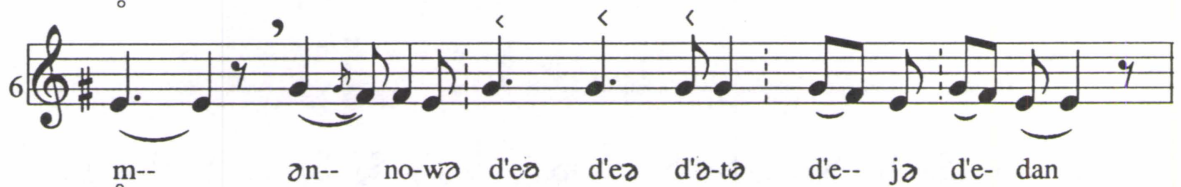

Nuottiesimerkki 19. Nganasanien allegorisen laulun katkelma. Äänite on Juri Šeikinin. Tekstilitteraatio pohjautuu Eugen Helimskin tulkintaan mutta eroaa siitä hieman. Edellä olevassa kaaviossa annettu teksti esiintyy notaation riveillä 3-6. 
Nuottiesimerkin 19 sävelmä liikkuu suuren terssin $(e f g i s)$ kolmella sävelellä, ja säe jakautuu neljään osaan, jotka vastaavat pääosin Helimskin neljää segmenttiä. Tekstin melodista käsittelyä en tässä ryhdy erittelemään. Nganasanien musiikista ei ole kirjoitettu paljon, ja sen tutkijoita lienee vain kaksi, eestiläinen Triinu Ojamaa ${ }^{37}$ ja Taimyrilla asuva ukrainalainen Oksana Dobžanskaja ${ }^{38}$. Musiikkianalyysin aika on siis vasta tuonnempana.

Eri allegorisilla lauluilla on eri avaimet, ja täten laulujen laatijoilta, esittäjiltä ja kuulijoilta on vaadittu aika lailla tuossa muistinvaraisessa kulttuurissa. Kieltä tällä tavalla taiteeksi muuntavaa tekniikkaa ei edellä käsittelemissäni kulttuureissa ole esiintynyt. Toisaalta kuitenkin koltat ovat käyttäneet samankaltaista tekniikkaa sommitellessaan leutten säkeitä. Heidän tekniikalleen on ollut ominaista sanansisäisen tavujärjestyksen sekoittelu niin, että leuttekieli on saatu erottumaan normaalikielestä ${ }^{39}$. Vaikka Kuolan saamelaisilla on ollut yhteyksiä läntisiin nenetseihin, tekniikkaa ei mielestäni ole tarpeellista pitää hiljan tapahtuneena samojedilainana Kuolan saamelaisten keskuudessa. Asia jää puhtaan arvailun varaan, mutta mahdollisesti tekniikalla on vahemmat ja syvemmälle tunkeutuvat yhteiset juuret.

Nganasanien kahdeksantavuisten samaanilaulujen ( $\eta 20$ baly 'šamaanin laulu') tekstien käsittelyyn liittyy samanlaisia piirteitä kuin edellä, mutta niitä ei ole tutkittu juuri lainkaan musiikin yhteydessä. Kiintoisasti šamaanien rituaaleissa esiintyy monenlaista tyyliä, mutta samaani käyttää nimenomaan kahdeksantavuista juurimittaa välittäessään kuulijoille supranormaalien olentojen viestit tuonpuoleisesta. Tämä piirre on kiintoisa ja pidän sitä paralleelina tunguusien ja turkkilaisten tavalle laulaa saduissa ja tarinoissa keskushahmon repliikit oktosyllabisella mitalla.

Nenetsit asuvat Jäämeren tuntumassa, nganasanien ja Kuolan saamelaisten välisillä laajoilla alueilla. Niemen ${ }^{40}$ mukaan oktosyllabisuutta esiintyy milloin selkeästi, milloin kätkettynä täyte- eli nollatavujen joukkoon. Koska Niemi on esitellyt analyysituloksiaan jo muissa yhteyksissä, nenetsejä ei tässä erikoisemmin tarkastella. Todettakoon vain, että kahdeksantavuisuus kuului heidänkin šamanistiseen kulttuuriinsa. Olkoon esimerkki 20 lyhyenä näytteenä selkeästä kahdeksantavuisuudesta ${ }^{41}$. Melodia etenee nopeassa tempossa kahdella sävelellä ja säe jakautuu kahteen osaan: se alkaa neljän tahdin leksikaalisella tekstillä ja päättyy kahden tahdin sekreemiosaan. Tämän äänitteen ensisäkeessä laulaja joko "kompastui" tai lisäsi tarkoituksella ylimääräisen tahdin (tahti ø). Metriikkaa noudattavan tekstin ydin kuuluu:

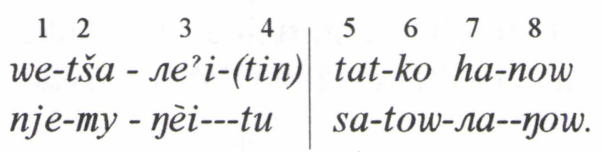

Laulaja toistaa kaksijakoisella melodialla noususäkeen (we-tša-le"i-ti) kahteen kertaan ja siirtyy sitten laskusäkeeseen (tat-ko ho-now), johon liittyvä 
3-jakoinen melodia toistuu myös sakreemissä ho-how - ho-how. Laulu on muodollisesti säännöllinen mutta aivan eri tavalla kuin turkkilaisilla kansoilla. Melodia rakentuu kahdelle sävelelle, joiden välinä on pieni terssi.

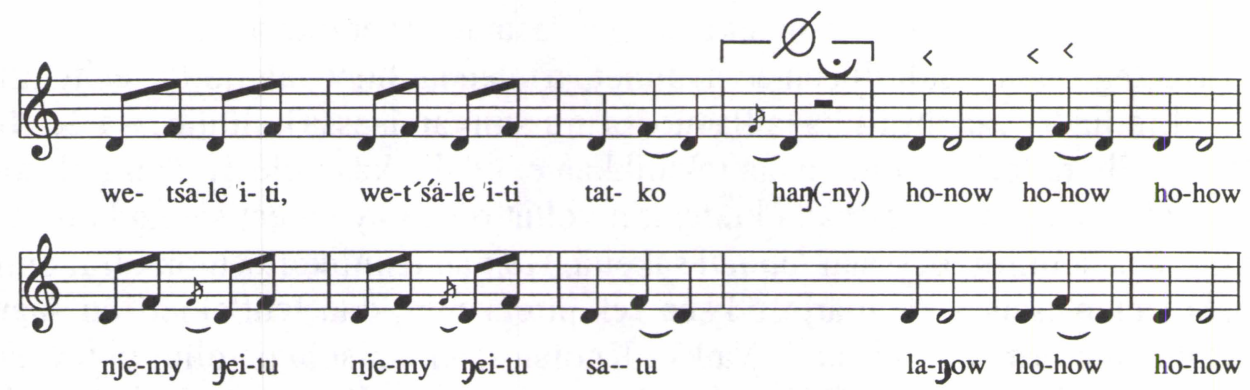

Nuottiesimerkki 20. Metsänenetsiläisen šamaanilaulun kaksi säettä. Merkki " tarkoittaa glottaaliklusiilia. Tekstin varmennusta vailla oleva tulkinta on Jarkko Niemen (1992, nuotti 29), sillä ainoa metsänenetsin jättämä merkintä tästä laulusta on sen vahasylinteriin kirjoitettu nimi: wetšale"iti. Niemen suullisen selostuksen mukaan tämä laulu ei kuitenkaan edusta millään erityisellä syyllä nenetsiläistä oktosyllabista laulua yleensä, sillä tundranenetsien šamaanilaulut ovat tätä paljonkin monimutkaisempia.

\section{A.7. Länsi-Siperian ugrilaiset}

Uralin itäpuolen alangoilla virtaa jättimäinen $\mathrm{Ob}$ monine sivujokineen. Pohjois-Euroopan komit kutsuivat Obin vesistön läntisiä ugrilaisia nimellä "voguli" ja itäisiä nimellä "ostjakki", jotka sanat sittemmin venäläiset omaksuivat. Näiden omakieliset nimitykset taas ovat mansi ja hanti. Heidän laulujensa sävelmistä väitellyt A. O. Väisänen ${ }^{42}$ oli laajahkolla aineistollaan todennut, että obinugrilaisen laulun moninaisuudesta huolimatta kaksisäkeisyys ja nelinousuinen säerakenne ovat varsin luonteenomaisia. Vaikka hän löysi ugrilaisille sävelmille vastaavuuksia mm. Suomen ja Inkerin runosävelmistä, hän piti samankaltaisuutta sattumana eikä geneettisen suhteen todisteena. Myös ugrilaisia kieliä hallitseva Katalin Lázár ${ }^{43}$ kuvaa yksi- ja kaksisäkeisiä lauluja ja toteaa, että tavujen lukumäärä saattaa vaihdella ylimääräisten täytetavujen vuoksi. Jotkut täytetavut koristavat rytmiä ja tihentävät tempoa. Otettakoon esimerkiksi kahden melodiasäkeen mittainen tekstisäe, jossa ylimääräinen täytetavu on alleviivattuna keskellä oktosyllabista riviä: 
Melodian metrisen pohjakaavan mukainen (eli teoreettinen) tahtilaji olisi kai $6 / 8$, mutta laulaja toteuttaa tätä jatkuvasti muunnellen, mikä käy ilmi myös yllä olevan säkeen musiikillisesta toteutumasta ${ }^{44}$.

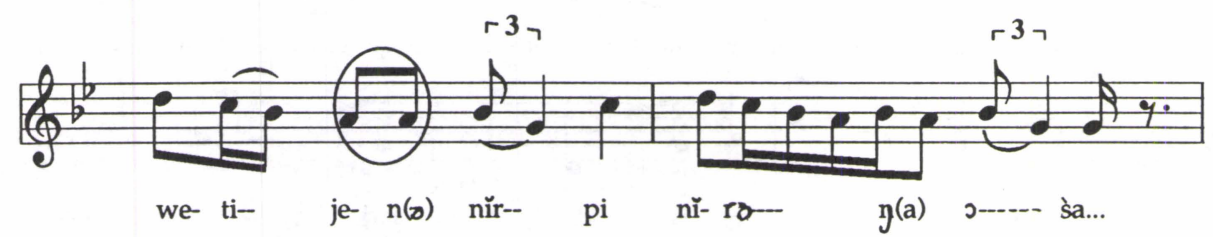

Jotta metrisesti painollinen tavu osuisi yhteen melodian painon kanssa, laulajat ovat saattaneet lisätä tavun eteen ylimääräisen tavun. Lázárin tämä havainto tarkoittaa, että ugrilaisillakin musiikillinen ajattelu perustuu ainakin tietyissä laululajeissa kiinteään musiikilliseen metriin, mutta että teksti ei ole ehdottoman kiinteästi tavusidonnainen. Seuraavana oleva sävelmä etenee niin, että esisäkeen metrinä on $6 / 4$ ja jälkisäkeen oikeastaan $5 / 4$. Tekstissä säeparin mittainen alarivi on kahdeksantavuinen:

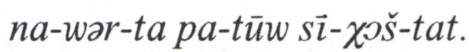

Laulaja on käsitellyt sitä niin, että hänen oli lisättävä esisäkeen loppuun kahden neljäsosan kestoinen lisätavu, joka on ympyröity nuotissa. Itse asiassa ylempi rivi on alemman kanssa liki identtinen, mutta kuitenkin aivan erilainen:

$$
\chi u-\chi \partial t-t a \text { pa-tūw s } \vec{\imath}-\chi \supset \check{s}-t a t .
$$

Erilaisuus syntyy siitä, että laulaja on lisännyt sanojen loppuun lisätavuja ja saanut sanat pitenemään. Esim. ylärivillä sanat $p a-t \bar{u} w$ si- $\chi \supset \breve{s}$-tat saavat laulukielellä asun $p a-j \underline{j}-t \bar{u}-w \underline{\underline{\partial}} s \bar{i}-\underline{j} \underline{-}-\chi \rho-s ̌ \partial-t a-\underline{t a}$, jossa lisäykset on alleviivattu. Laulettuna nämä näyttävät seuraavilta ${ }^{45}$.

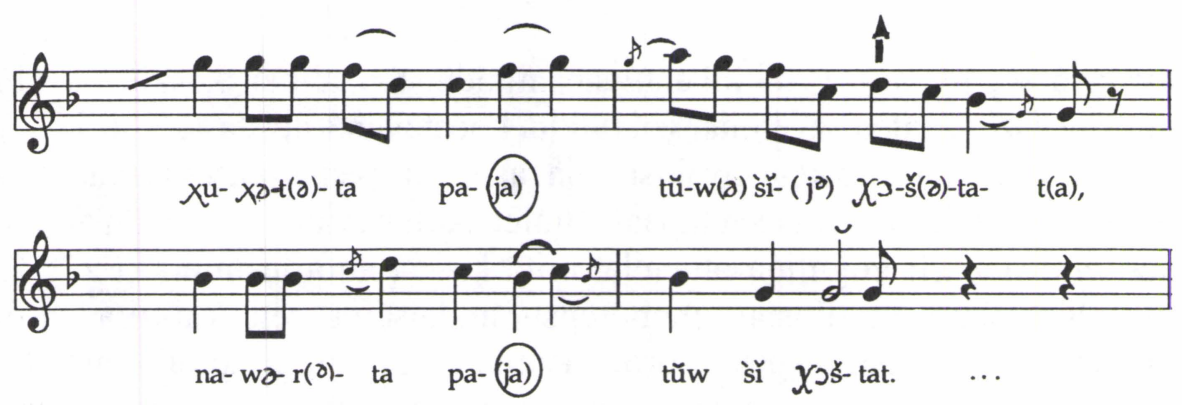



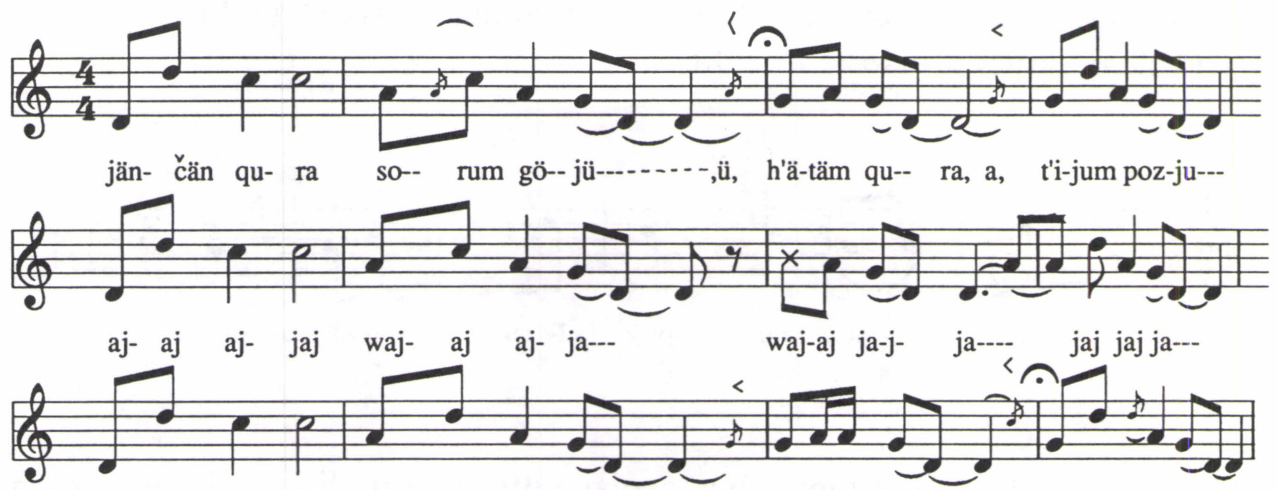

al-- sir xan- si mai- jei jon- su---......, u, mar-se-re v'ä-- rä, $\sigma$, mai-jei v'är-su---

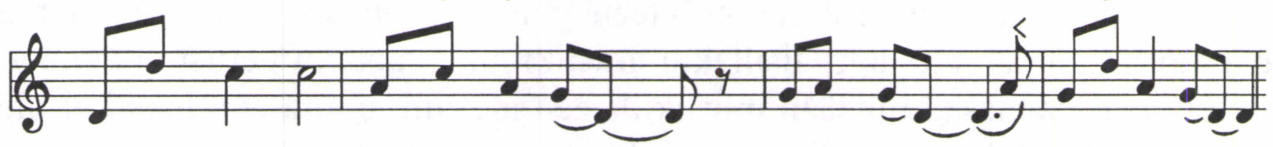

aj-- jej jaj- ja aj-- jaj jaj-ja---

Nuottiesimerkki 21**. Hantilainen henkilökohtainen laulu. (Äänite: KhP I:6.)

Myös hantien laulustossa esiintyy mitan melko säännönmukaista toteuttamista. Olkoon tästä näytteenä laulu Aipaštarne ar (nuottiesimerkki 21), joka oli laulajan 1800-luvun lopulla syntyneen isoäidin oma laulu ja kuuluu siis henkilökohtaisten laulujen genreen ${ }^{46}$.

Laulu koostuu oktosyllabisesta tekstistä (esisäe + jälkisäe: $A B$ ), jota seuraa saman pituinen ja mielestäni erikoislaatuisella so-pentatonisella melodialla esittämä sekreeminen säepari. Itse tekstin rakenne on säetasolla (kuulovaikutelman perusteella):

$\begin{array}{ll}\text { jän-cän qu-ra } & \text { so-rum gö-jü } \\ \text { h'ä-täm qu-ra } & \text { t'i-jum poz-ju } \\ \text { al-sir han-si } & \text { mai-jei jon-su } \\ \text { mar-sere v'ä-rä } & \text { mai-jei v'är-su }\end{array}$

Sävelistä $d^{1}, g^{l}, a^{l}, c^{2}, d^{2}$ rakentuvan moodin tonaalinen keskiö do (1) on matalin sävel $d^{l}$, ja siten sävelmän voi tulkita koostuvan asteista $1,3,4,5,1$, joka ymmärtääkseni ei ole kaikkein tavallisimpia rakenteita pentatonisessa maailmassa.

Samaan kahdeksantavuiseen tapaan kuulee laulettavan hantien länsipuolella asuvien mansien eli vogulien alueella, mitä kuvaa nuottiesimerkki 22. Tämä pentakordisävelmä kuullostaa itämerensuomalaiselta sen kaikilla tasoilla. Moodi käyttää selkeästi re-pentakordin asteita 1-5, mutta muotorakenne koostuu kolmisäkeisistä yksiköistä, mikä on ugrilainen mutta ei itämerensuomalainen piirre: $\mathrm{ABB} A B B \mathrm{BBB} A B B$. 


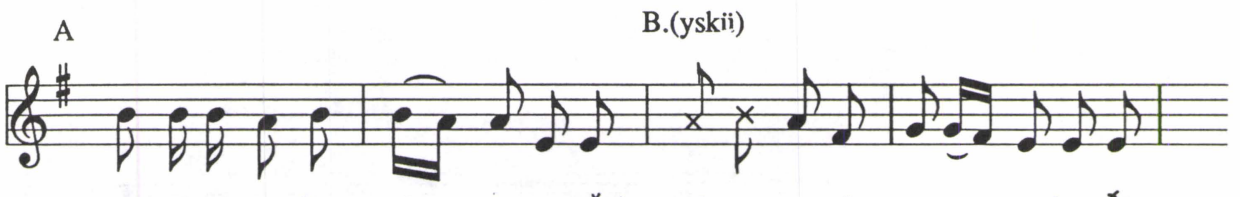

nö- römöy-gat-kut tö--- pem-na-tšoi, ul- ge mo-gla soy-te mni pa-đor
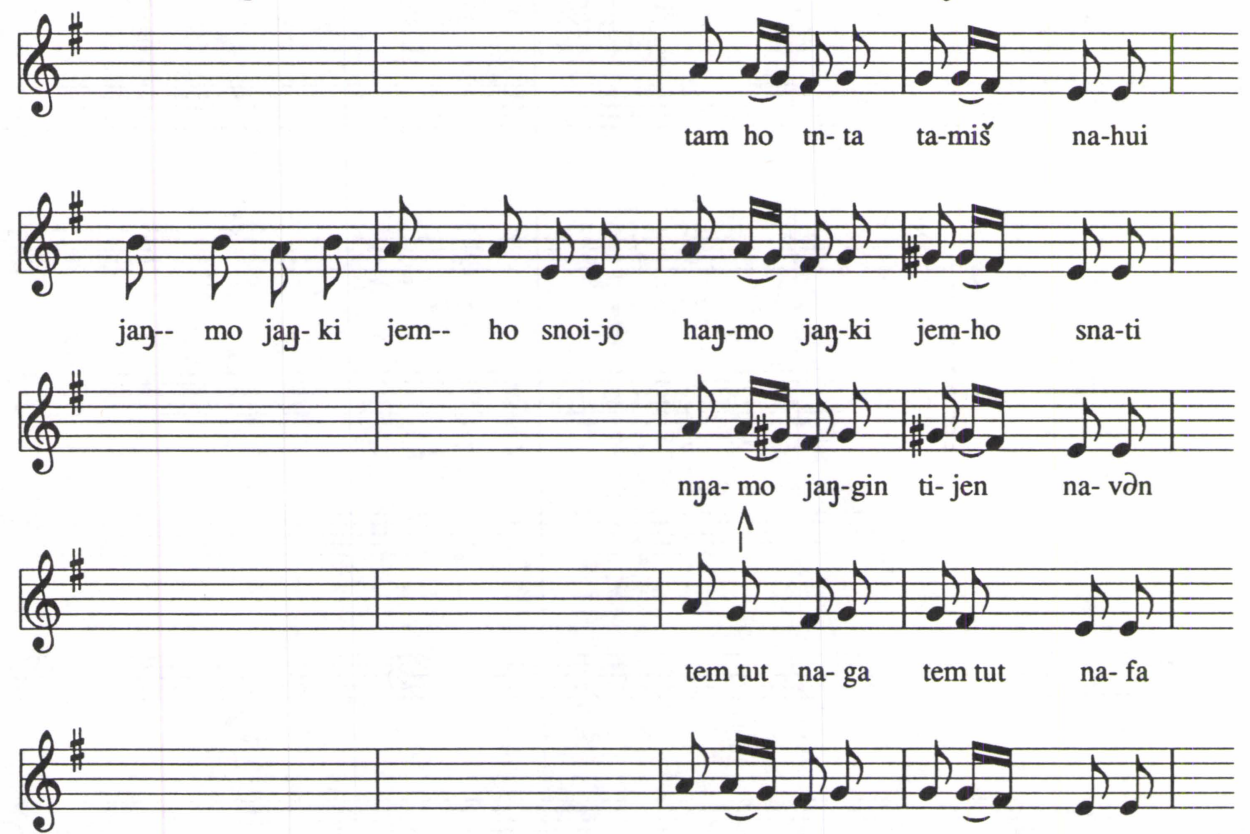

te- ma ke-so ja- jem no-hot

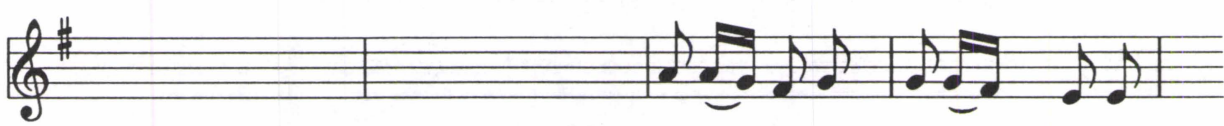

tam-to xn-ta te-mi je- hot

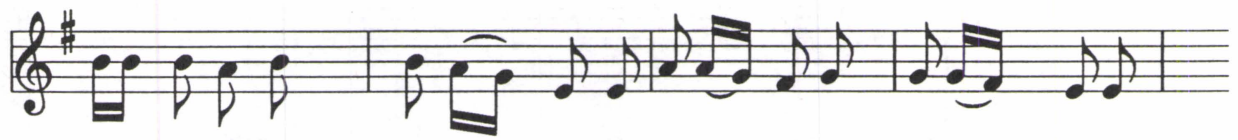

ta-ma-ho xm-ta te- mi je- je gö-sö ray-so ray-müi ho-to

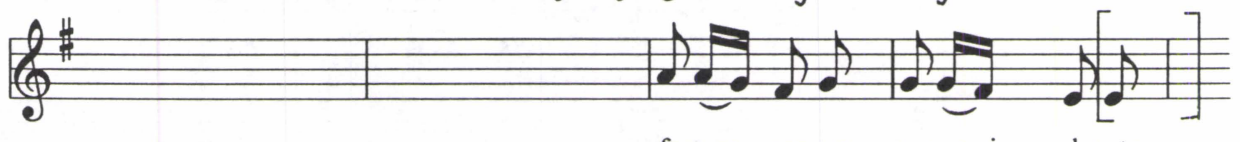

fem-so ray-so ray-mui ho- to

Nuottiesimerkki 22**. Mansilaulu. (Äänite: Katalin Lázárin Kansanperinteen laitokselle luovuttaman kokoelman laulu n:o 2.) 

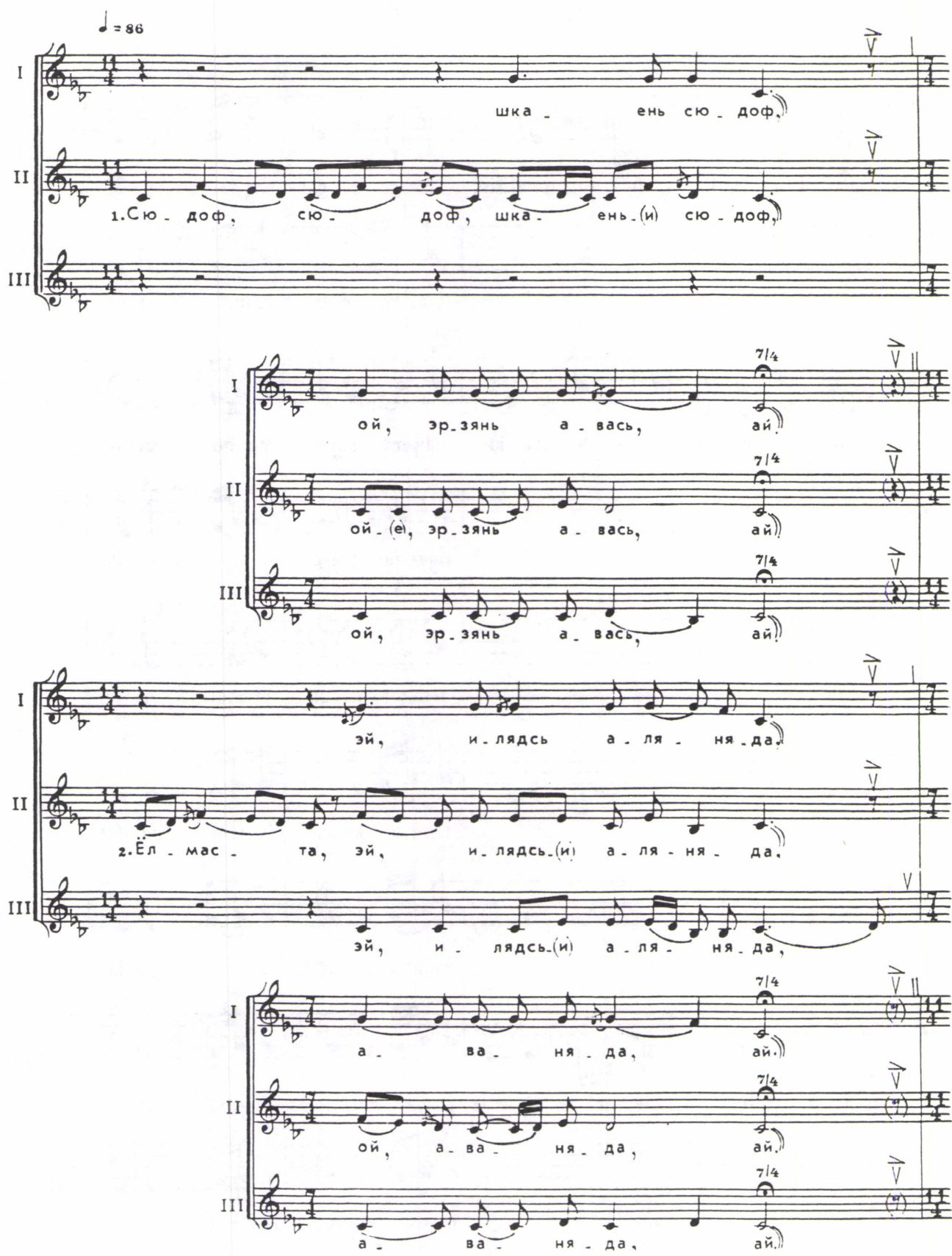

Nuottiesimerkki 23. Mokšalainen laulu, jossa on kahdeksantavuinen metrinen pohjakaava. Kolmea ääntä laulava kuoro lisää siihen tavuja sekä kertosäkeen. Laulu kuuluu lyyriseen laulustoon, jonka aiheena on tytön asema patriarkaalissa suvussa. Sävelmän on nuotintanut ja julkaissut Nikolai Bojarkin (1984, sävelmä 43). 


\section{A.8. Volgansuomalaisen kahdeksantavuisuuden ongelma: mordvat}

Siirryttäessä Inkeristä hieman itään alkaa vepsäläisten hajanainen asuinalue. Vepsäläiset kuuluvat itämerensuomalaisiin, mutta kalevalamittaa heiltä ei ole tavattu. Historian näkökulmasta en pitäisi vepsäläisiä yhtenäisenä kansana tai heimona vaan mieluummin monien varhaisempien pikkuheimojen itämerensuomalaistuneena reliktinä. Toisin sanoen heidän esi-isissään oli yhtä hyvin läntisten merjalaisten kuin itäisimpien itämerensuomalaisten jäseniä. Merjahan oli volgansuomalainen heimo. Volgansuomalaisilta mareilta sen kummemmin kuin permalaisilta komeilta tai udmurteilta ei ole tavattu nelipolvitrokeen kaltaista metristä perinnettä. Tältä kannalta voisi arvella, että ennen itäslaavilaisen vaikutuksen ajanjaksoa Itämeren ja mordvalaisten välillä asuneiden kulttuuri oli vahvasti volgansuomalaisten värittämää vielä keskiajan loppupuolella. Näistä osa sulautui slaaveihin ja otti 'oikeauskoisen identiteetin, jolloin heistä tuli Keski-Ruotsin kauppiaiden nimen mukaan ruuseja, ortodoksisia venäläisiä. Läntisimmät sulautuivat itämerensuomalaisiin ja heidän uudeksi identiteetikseen alkoi muodostua se, jota me nyt kutsumme vepsäläiseksi. Tästä näkökulmasta ei ole kovin outoa, ettei vepsäläisten tiedetä käyttäneen lauluissaan Kalevalan mittasysteemiä - vaikka he soittivat itämerensuomalaisille perin ominaista kanteletta.

Volgansuomalaisten mordvalaisten usein moniääninen musiikki ${ }^{47}$ eroaa rajusti (ilmeisesti bolgaarien, tataarien ja mongolienkin perinteitä omaksuneiden) marien yksiäänisestä pentatoniikasta. Mordvalaisen moniäänisyyden alkuperä on edelleen hämärä. Slaavilaista lainaa se ei ole. Tarttolainen tutkija Udo Kolk oli jo 1970-luvulla julkaissut väittämän, jonka mukaan setukaisten tyylillisesti ei-venäläinen polyfonia on mordvalaisperäistä ${ }^{48}$. Aiheeseen on hiljan palannut Ingrid Rüütel samoin tuloksin ${ }^{49}$. Mordvan lauluston runkona on joukko isosyllabisia mittasysteemeitä, joissa tavuluku liikkuu 7:n ja 17:n välillä. Näistä kahdeksantavuinen on ominainen etenkin Erzän heimon laulustolle. Nuottiesimerkkinä 23 on kuitenkin mokšalainen näyte, jonka teksti on seuraava:

$$
\begin{aligned}
& \text { sju-dof, sju-dof } \\
& \text { Jol-mas-ta (ej) } i \text {-lads' } \\
& \text { od-nas-ta (ei) i-lads' }
\end{aligned}
$$

Teksti koostuu perussäkeestä ja (alleviivatusta) kertosäkeestä. Vaikka laulajat lisäävät (alleviivattuja) tavuja $e i$, oj jne., kahdeksantavuinen perusta on näkyvissä. Toisen ja kolmannen säkeen ensijalassa on kolme tavua, mutta muutoin näissä, kuten laulun loppusäkeissäkin, oktosyllabisuus on selvä:

$$
\begin{aligned}
& \begin{array}{llllllll}
1 & 2 & 3 & 4 & 5 & 6 & 7 & 8
\end{array} \\
& \text { Jol-mas-ta } i \text {-lads' | a-läš-nä-da. }
\end{aligned}
$$


Olisi houkuttelevaa ajatella, että morvalaisella perinteellä olisi sukuyhteys itämerensuomalaiseen. Kielentutkijana Mikko Korhonen ${ }^{50}$ oli kuitenkin sitä mieltä, että geneettisen suhteen olettaminen johtaisi kielihistorialliseen mahdottomuuteen. Mitta ei myöskään ole valkovenäläistä lainaa 1600-luvulta, kuten on oletettu. Sen on täytynyt kehittyä itsenäisesti mordvan kielen omalta pohjalta, eikä tällä kehityshistorialla ollut yhteyttä kalevalamitan syntyyn.

Vaikka Korhosen perusteet ovat lingvistiset, on syytä mainita pari seikkaa. Hän piti todennäköisenä, että yli 6000 vuoden takaisen uralilaisen kauden ja noin 3000 vuoden takaisen volgalaisen kauden $^{51}$ välisenä aikana kieli oli luonteeltaan painoajoitteinen. Toisin sanoen puhuja rytmitti puhettaan siirtymällä pääpainolta toiselle. Pääpaino oli sanan ensitavulla, jonka jälkeisten muiden tavujen painoilla ei ollut suurta merkitystä. Jos uralilaiset laulajat olivat noudattaneet jotain säännöllistä metriikkaa, sen oli täytynyt mukautua painoajoitteeseen kieleen. Tuloksena olisi ollut dynaaminen mitta, joka olisi koostunut nousuista ja niiden välillä olevista laskuista. Lisäksi siinä olisi voinut toteutua isokronia: kaikki nousut ja kaikki laskut olisivat vieneet yhtä kauan aikaa. Toisin sanoen yksitavuista nousua olisi seurannut vaihteleva määrä sanan lopussa olleita tavuja, mutta määrästä huolimatta lasku olisi kestänyt yhtä kauan kuin nousukin. Tämä näyttäisi olleen aivan mahdollista suomalais-volgalaiselle ja sitä vanhemmille kieliasuille, sillä vielä tuolloin sanat olivat suhteellisen lyhyitä, ja äänteitäkin oli nykyistä vähemmän. Vaikka jo varhaisuralilainen kieli oli agglutinoiva ${ }^{52}$, sellaisia liiteketjuja kuin nykyisin ei ollut. Kun nykysuomessa esim. tie-sanan perään voidaan latoa kymmenenkin elementtiä (esim. tie|do-sta-ma-tto-m-uu-de-ssa-an-kaan), protouralin asut olivat lyhyempiä kuten:

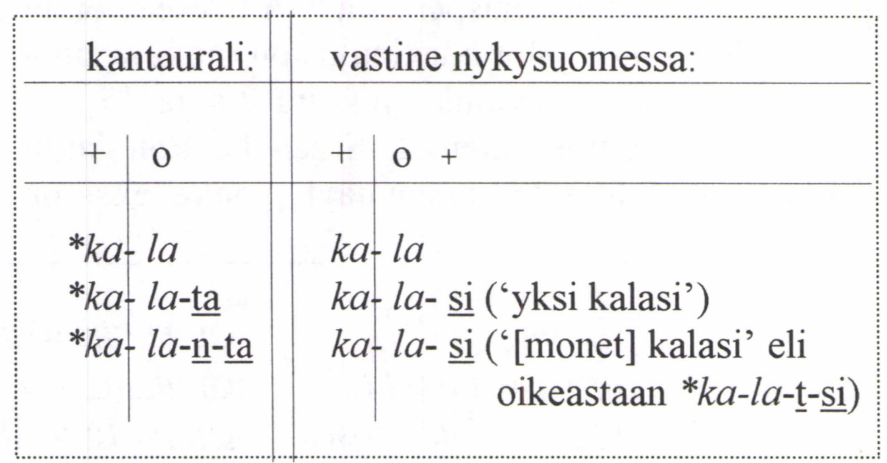

Korhonen ei puuttunut siihen, montako painollista nousua tällaisen laskevan dynaamisen mittajärjestelmän säkeessä olisi voinut olla. Tulkintani mukaan määrä olisi voinut olla joko kiinteä tai vaihteleva. Jälkimmäisessä tapauksessa systeemi olisi voinut toimia esim. seuraavaan tapaan, jossa $P$ tarkoittaa sanan pääpainollista ensitavua ja $\varnothing$ sanan painotonta laskutavua. Tässä laskevaa dynaamista mittaa kuvaavassa esimerkissä on kolme kuvitteellista säettä: 


\begin{tabular}{|c|c|c|c|c|c|c|c|c|c|c|c|c|}
\hline & + & 0 & + & 0 & + & 0 & + & 0 & + & 0 & + & 0 \\
\hline 1. & $\mathbf{P}$ & $\varnothing \varnothing$ & $\mathbf{P}$ & $\varnothing$ & $\mathbf{P}$ & б Ф & $\mathbf{P}$ & б Ø & $\mathbf{P}$ & б & & \\
\hline 2. & $\mathbf{P}$ & Ø & $\mathbf{P}$ & б & $\mathbf{P}$ & $\varnothing$ & $\mathbf{P}$ & ø & $\mathbf{P}$ & Ф Ф & $\mathbf{P}$ & Ø \\
\hline 3. & $\mathbf{P}$ & бөю & $\mathbf{P}$ & $\varnothing$ & $\mathbf{P}$ & Ø & $\mathbf{P}$ & ๓๗๗ & & & & \\
\hline
\end{tabular}

(On huomattava, että esimerkiksi karjalaisten itkut on toteutettu juuri tällä periaatteella, vaikkei karjala kuten ei saamekaan ole enää painoajoitteinen, ja vaikka laskut eivät suinkaan kestä yhtä kauan kuin nousut.)

Korhosen mukaan kantasuomessa tapahtuneiden kielellisten muutosten seurauksena pääpainoa seuraavilla tavuilla alkoi olla enenevästi merkitystä. Näin aiemman painoajoitteisen rytmittämisen sijasta kieli alkoi muuttua syllabiseen suuntaan. Tämä johti taas siihen, että myös laulun metriikka alkoi muuttua syllabiseksi, yksittäisiä tavuja korostavaksi, mikä johti kalevalaisen nelipolvitrokeen muotoutumiseen. Itse asiassa jo varhaiskantasuomessa sanan kolmattakin tavua oli alettu painottaa, mikä on merkittävä piirre sekä saamessa että itämerensuomessa yhä. Korhonen mainitseekin, että painojen "ansiosta puhe jaksottui yksi-, kaksi-ja kolmitavuisiksi tahdeiksi. Nelitavuiset ja sitä pitemmät sanat koostuivat kahdesta tai useammasta tahdista." 53 . Ideaa voi havainnollistaa seuraavalla teennäislauseella:

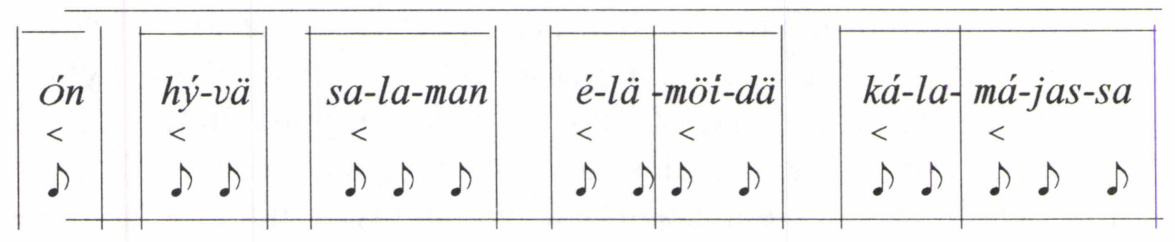

Sama prosessi oli tapahtunut mordvan alueella erityisesti erzäläisten puheessa. Muistettakoon, että Erzän heimo oli elänyt varsin pitkällä lännessä, vaikka se on sittemmin joutunut muuttamaan Mokšan heimon itäpuolelle. Mordvan ja itämerensuomen piirissä oli siis tapahtunut samankaltaisia kielellisiä muutoksia. Ja koska syllabinen mitta ei istu painoajoitteiseen kieleen (jollainen mordvan ja suomen yhteinen emäkieli oli ollut), mordvalainen isosyllabisesti kahdeksantavuinen runomitta ei voi olla samaa kantaa kuin itämerensuomalainen. $\mathrm{Ne}$ ovat syntyneet toisistaan riippumatta.

Siis tiedämme, että vaikka kalevalamitta on itämerensuomalaisella kulttuurialueella varsin vahva, sitä ei esiinny saamelaisilla eikä vepsäläisillä. Se on geneettisesti erillisenä ilmiönä lähimmillä etäsukulaisillamme, mordvalaisilla, mutta sitä ei ole näiden naapureilla, mareilla, eikä näiden pohjoispuolella asuvilla udmurteilla eikä komeilla. Kun enää ei voida ajatella, että kalevalamitta olisi balteilta omaksuttu laina, vaan että pohjoisimmat baltit eli latvialaiset ovat saaneet tätä mittaa muistuttavan perinteensä lainana itämerensuomalaisilta, kokonaistilanne alkaa muodostua mielenkiintoiseksi. 


\section{B. Tuloksia ja päätelmiä}

Edellä on näytteitä noin 15 tunnin siperialaisesta ääniteaineistosta, jossa esiintyy vain muutamia oktosyllabisuuteen viittaavia tai liittyviä sävelmiä. Mielestäni tässä satunnaisotoksen kaltaisessa kokoelmassa on kuitenkin riittävästi sävelmiä, jotta on mahdollista esittää muutamia hypoteeseja. Aineisto tullee lähivuosina lisääntymään, jos kohta niiden laulajien määrä, jotka pystyvät luomaan perinteisin menetelmin uutta, on jo pieni, ehkäpä vain muutamia kymmeniä koko Siperiassa. Tässä suhteessa ei ole aihetta kovin suureen optimismiin. Mm. nganasanien kəjyəirśan tulevaisuus on heikommassa kantimessa kuin karjalaisen itkun. Tietenkin paikalliset taitajat luovat parhaillaankin uutta perinnettä. Koska kuitenkin taito generoida uusia lauluja vanhojen avainten avulla näyttää kadonneen, tulos ei ole enää kəjĐəirśaa sen kummenkin kun estradilla runona lausuttu karjalainen riittitekstikään on itkua.

Sanotun pohjalta uskaltaudun esittämään muutamia yleistyksiä. Lukijan on hyvä tietää, että itse suhtaudun niihin pelkkinä hypoteeseina.

\section{B.1. Kahdeksantavuisuuden kontekstit}

Kahdeksantavuinen mitta näyttää Siperiassa kuuluneen kertoviin yhteyksiin tai samanistiseen perinteeseen. Kiintoisasti näiden kahden välinen yhteys on siinä, että molemmissa keskeisen hahmon (sankarin, jumalan tms.) lausumat ajatukset on tulkittu sanoiksi kahdeksantavuisen pohjakaavan avulla. Epiikka ja uskonto ovat liittyneet kahdeksantavuisuuteen myös itämerensuomalaisella alueella, sillä vanhimmat myytit ja šamanistiseksi tulkittu perinne on säilynyt juuri tämän runomitan kautta. Toisaalta kahdeksan tavun säerakenteesta oli tullut kaiken muun itämerensuomalaisen laulun väylä paitsi itkujen. Tästä näkökulmasta meikäläinen perinne eroaa selvästi itäpuolellamme olevien kulttuureiden sisällöistä, joissa oktosyllabisuus elää vain yhtenä monen muun mitan rinnalla.

Oktosyllabisuuden yhteys epiikkaan jää hämäräksi kuitenkin mordvalaisella alueella. Tässäkin kirjoituksessa oleva esimerkki on luonteeltaan lyyrinen. Sen sijaan ugrilaisessa perinteessä mitta näyttää kuuluneen sekä uskontoon että henkilökohtaiseen lauluun, joka liikkuu epiikan rajamailla. Hämäräksi jää sekä jakuuttien juhlalaulujen kahdeksantavuisen perinteen todellinen luonne (esimerkki 14) että myös jukagiirien marginaaliseksi arveltu laulusto. Epävarmuudesta huolimatta haluaisin yhä painottaa tätä: Tornionjoesta Amurille jumalten viestit ja sankarien ajatukset on valettu lauluiksi kahdeksantavuisella muotilla. 


\section{B.2. Pohjakaavan toteuttamisen typologiaa}

Kahdeksantavuinen pohjakaava näyttää kaikkialla toteutuvan selkeän syllabisesti ja runojalan tasolla miltei yksinomaan trokeisesti $(-0)$. Jos tarkastelee tekstejä elävän laulun osana, voi havaita, että kaavan toteuttamistavat voi jakaa neljään luokkaan.

1) Itämerensuomalaisten ja turkkilaisten tapaa soveltaa kahdeksantavuista pohjakaavaa voidaan kutsua kaavan puhtaaksi toteutumaksi, sillä laulettu teksti vastaa pohjakaavaa.

2) Tunguuseille näyttää olleen ominaista soveltaa kaavaa niin, että tuloksena on kaavan supistava toteutuma. Yhdessä säkeessä runojalat täyttyvät 8 tavulla, toisessa eivät. Tämä johtuu siitä, että laulaja saattaa jatkaa sanan viimeistä tavua seuraavalle laskulle. Tuloksena laulussa saattaa siis olla myös 7- tai 6-tavuisia säkeitä. Ilmiö on tuttu myös itämerensuomalaisella alueella, mutta tunguuseilla se näyttää säännöltä eikä poikkeukselta. Kuitenkin supistaminen näyttää olleen mitan yleisintä soveltamista koko euraasialaisella alueella.

\begin{tabular}{|c|c|c|c|c|}
\hline \multirow{2}{*}{$\begin{array}{c}\text { TOTEUTUMAN } \\
\text { TYYPPI }\end{array}$} & \multicolumn{4}{|c|}{ РОНJAKAAVA } \\
\hline & 0 & $+\quad 0$ & +0 & + \\
\hline A. PUHDAS & $\begin{array}{l}s i-n i- \\
\text { Gee-le }\end{array}$ & $\begin{aligned}- & s e i-n a ̈ n \\
& c e r-d \ddot{n} n\end{aligned}$ & $\begin{array}{l}\text { siir }-t \ddot{a}- \\
k e-\quad l i-\end{array}$ & $\begin{array}{l}\text { mät }-t \ddot{a} \\
\text { rim- de }\end{array}$ \\
\hline B. SUPISTAVA & $\begin{array}{l}e-m \ddot{a} \\
\check{s e n}-d e\end{array}$ & $\begin{array}{l}a u-t a \\
h o----\end{array}$ & $\begin{array}{l}\text { las - ta-- } \\
\text { jän - de }\end{array}$ & $\begin{array}{l}\text { nes------ } \\
\text { le - ni }\end{array}$ \\
\hline C. LAVENTAVA & $w e-t i$ & $\frac{(j e-n \partial)}{n i r-p i}$ & $n i-r \partial \eta$ & o-sa \\
\hline D. PILKKOVA & Segmentt & Segmer & $\mathrm{t}_{2} \quad \ldots$ & mentti $n$ \\
\hline
\end{tabular}

3) Ugrilaisella ja mordvalaisella taholla laulajat saattavat käsitellä kahdeksantavuista pohjakaavaa lisäämällä säkeiden sisään ylimääräisiä tavuja. Pinnalta säe ei aina näytä laisinkaan oktosyllabiselta. Tällaista kutsun kaavan laventavaksi toteutumaksi.

4) Samojedien tekniikkana on taas voinut olla säkeen tavurakenteen pilkkominen ja uusien tavujen lisääminen siihen tiettyjen sääntöjen mukaan. Kutsun tällaista pilkkovaksi toteutumaksi. Tavujen lisääminen onkin tekijä, joka on yhteinen laventamistekniikan kanssa. 


\section{B.3. Musiikki}

Kahdeksantavuisella mitalla etenevää tekstiä on laulettu koko Euraasiassa hämmästyttävän yhdenmukaisilla melodioilla. Moodit pohjautuvat yleensä (pentatonisen tai diatonisen pohjasysteemin) kolmelle, neljälle tai viidelle peräkkäiselle sävelelle eli eli yleensä asteille 1-5. Tässä valittu esimerkkisävelmistö jakautuu moodirakenteeltaan seuraaviin ryhmiin, jotka näkyvät oheisesta taulukosta. Siinä pohjasysteemi ilmoitetaan $c$-pohjaisena eli $d o=$ $c^{l}, r e=d^{l}$ jne. Täten mm. so-pentatonisessa systeemissä 1 . asteena on sävel $a^{l}$.

Asetelmasta näkyy, että tunguuseilla, Altain turkkilaisilla sekä hanteilla esiintyy pentatoniikkaa, mutta moodit ovat yleensä vain nelisävelisiä. Sama koskee heptatoniselle systeemille pohjautuvia moodeja, jotka ovat tri-, tetra- tai pentakordeja ja yleensä joko do- tai re-sävyisiä. (Näin satunnaisen aineiston pohjalta mitään systematiikkaa on kuitenkin turha tässä nähdä.)

Melodia etenee syllabisesti suhteellisen verkkaisella ja vakaalla tempolla. Musiikin metri on milloin kaksi-, milloin kolmi- tai viisijakoista. Keskeistä on muodon jonomaisuus. Iteroivana yksikkönä on kolme päätyyppiä: (1) yhtä tekstisäettä vastaa yksi sävelmäsäe; (2) kahta tekstisäettä vastaa kaksi komplementaarista sävelmäsäettä tai (3) kahta tekstisäettä vastaa yksi sävelmäsäe.

(1)

(2)

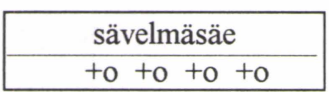

\begin{tabular}{|c|c|}
\hline sävelmäsäe A & sävelmäsäe B \\
\hline to to to to & to to to to \\
\hline
\end{tabular}

(3)

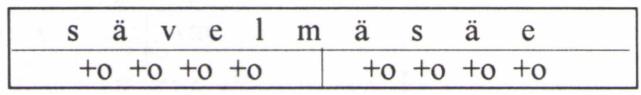

Näitä kolmea säerakennetta voidaan pitää kulttuurisina markkereina siinä mielessä, että yhteisöjen jäsenet ovat oppineet erottamaan ne kulttuurinsa muista laululajeista. Näiden säerakenteiden kautta ihmiset kuulivat jotain poikkeuksellista kuten myyttejä, henkien viestejä ja kulttuuriheerosten ja sankarien viisauksia. 


\begin{tabular}{|c|c|c|c|c|}
\hline $\begin{array}{l}\text { ESIME } \\
\text { NUM }\end{array}$ & $\begin{array}{l}\text { RKIN } \\
\text { ERO }\end{array}$ & POHJASYSTEEMI & $\begin{array}{l}\text { MOODIN } \\
\text { ASTEET }\end{array}$ & $\begin{array}{l}\text { MOODIN } \\
\text { SÄVELET }\end{array}$ \\
\hline Hanti (Ob-ugr.) & 21 & so-pentatoninen & $1-3,4,5,1$ & $a^{1} d^{2} e^{2} g^{2} a^{2}$ \\
\hline Evenki (Tung.) & 6 & so-pentatoninen & $1,2,3,4$ & $a^{l} c^{2} d^{2} e^{2}$ \\
\hline Udehe (Tung.) & 8 & so-pentatoninen & $4-1,2,3$ & $e^{l} a^{1} c^{2} d^{2}$ \\
\hline Nanai (Tung.) & 9 & $r e$-pentatoninen & $1,2,3,4$ & $d^{l} e^{l} g^{l} a^{l}$ \\
\hline Tuva (Turk.) & 11 & $r e$-pentatoninen & $1,2,3,4,5,1$ & $d^{l} e^{l} g^{l} a^{1} c^{2} d^{2}$ \\
\hline Tuva (Turk.) & 13 & $m i$-pentatoninen & $1,2,3,4$ & $e^{l} g^{l} a^{l} c^{2}$ \\
\hline Tuva (Turk.) & 12 & do-heptatoninen & $1,2,3,4,5$ & $c^{l} d^{l} e^{l} f^{l} g^{l}$ \\
\hline Azer (Turk.) & 10 & do-heptatoninen & $1,2,3,4,5$ & $c^{l} d^{l} e^{l} f^{d} g^{l}$ \\
\hline Jakuutti (Turk.) & 14 & do-heptatoninen & $1,2,3,4$ & $c^{l} d^{l} e^{l} f^{l}$ \\
\hline Eveeni (Turk.) & 16 & do-heptatoninen & $1,2,3$ & $c^{l} d^{l} e^{l}$ \\
\hline Jukagiiri (Paleosiper.) & 18 & do-heptatoninen & $1,2,3$ & $c^{l} d^{l} e^{l}$ \\
\hline Jakuutti (Turk.) & 15 & $r e$-heptatoninen & $1,2,3$ & $d^{l} e^{l} f^{l}$ \\
\hline Metsänenetsi (Samoj.) & 20 & re-heptatoninen & $1,2,3$ & $d^{l} e^{l} f^{l}$ \\
\hline Mansi (Ob.-ugr.) & 22 & re-heptatoninen & $1,2,3,4,5$ & $d^{l} e^{l} f^{l} g^{l} a^{l}$ \\
\hline
\end{tabular}

Taulukko oktosyllabista metriikkaa esittelevien sävelmien moodeista.

\section{B.4. Kysymyksiä}

Oktosyllabinen perinne näyttää puetun samankaltaisin tyylielementein ja kytketyn samankaltaisiin sosiaalisiin ja taiteellisiin yhteyksiin laajalla ja kolme suurta kielikuntaa kattavalla alueella. Ensimmäinen kysymys kuuluu: onko mahdollista, että samankaltaisuuksilla on yhtäläinen alkuperä? Toinen kysymys kuuluu: miten eri toteutumat suhteutuvat toisiinsa ajallisesti? Kuinka vanha on esim. puhdas toteutuma, kuinka vanha on pilkottu?

Vaikka kalevalamitta olisi ollut käytössä jo kolmisen vuosivuotta, voiko sillä olla yhteys obinugrilaisten kahdeksantavuiseen mittaan? Tai turkkilaiseen tai tunguusilaiseen? Jos olisi, miksi mitta ei ole yhteydessä mordvalaiseen?

Tunguuseilla, turkkilaisilla, samojedeilla, ugreilla ja itämerensuomalaisilla mitta näyttää liittyneen vanhaan šamanismiin ja epiikkaan. Jos näin valtavalla alueella on elänyt samanlainen mitta samoissa konteksteissa, voidaan olettaa, ettei samankaltaisuus ole vain sattumaa. Voidaan olettaa, että mittasysteemi on erittäin vanha, ja että oktosyllabisuudella on yhteiset, vuosituhansien takaiset juuret. Tämän vuoksi mm. Tulimaan Selk'nam-intiaanien šamanistisen, kahdeksantavuisen lauluston voi väittää tyyliltään vanhaksi kantasiperialaiseksi reliktiksi.

On huomattava, ettei oktosyllabisuus ole vanhastaan tai vahvana kuulunut edellä mainittujen kansojen etelä- ja länsipuolella eläneiden indogermaanisten kansojen kulttuureihin. Se puuttuu liettualaisen kansanlaulun vanhoista pohjakaavoista ja venäläinen kansanlaulu omaksui sen korkeakulttuurista vasta 
1600-luvulla. Toisaalta sekä veda-lauluissa että Rāmāyanassa esiintyy slokaniminen metri, joka koostuu $2 \times 8$ tavun mittaisista säkeistä. Mitenkään suosikkimittana sitä ei voi pitää, mutta se oli jo pari vuosituhatta sitten. Ilmeisesti oktosyllabisuus oli indogermaanisille kielille sopimaton.

Hypoteesin tueksi voidaan esittää joitakin sellaisia ikivanhoja kontakteja osoittavia seikkoja, jotka yhdistävät jonkin itämerensuomalaisen elementin Siperian kautta Amerikkaan saakka. Tällainen on mm. myytti, jonka mukaan maailma syntyi vesilinnun sukellettua hakemaan maata meren pohjasta. Oletuksen mukaan myytti ei ole voinut syntyä kuin kerran, ja sen tunsi jo se väestö, josta uralilaiset kansat (ja jukagiirit) sittemmin polveutuivat ${ }^{54}$. Sajanin ja Altain turkkilaisten joillakin perinteillä on vastaavuuksia Itämerellä. Näihin epäselviin samankaltaisuuksiin kuuluu esim. šamaanirumpuun liittyneitä piirteitä, joista mm. Ernst Emsheimer on kirjoittanut ${ }^{55}$. Edellä on lisäksi paljastunut, että turkkilaisten kansojen perinteissä esiintyvä vaihtuva metriikka (jonka erikoistapauksena voitaisiin pitää $\mathrm{mm}$. aksak-metriä), toistuu runolaulussa yhtenä erikoisuutenaan 5/4 -metrissä etenevä kalevalansävelmä.

Mitan puuttuminen vanhastaan volgansuomalaisesta kulttuurista voisi olla selitettävissä vahvan indoiranilaisen vaikutuksen seuraukseksi. Nimittäin monet suomalais-ugrilaiset kansannimet näyttävät juontuvan kanta-arjalaiselta suunnalta. Toisin sanoen suomalais-ugrilaiset kansat olisivat saaneet nimensä etelän suunnalla asuneilta naapureiltaan. Nimiä antaneita sanoja ovat voineet olla esim. kanta-arjan *martas 'kuolevainen' tai *mrtas 'kuollut' tai muuan arjalainen 'nuorta miestä' tarkoittanut sana. Näihin liittyisivät sellaiset kansannimet kuten mordva, udmurt ja muroma sekä merja ja mari, joka tarkoittaa 'miestä' ja 'tšeremissiä'. Jo Castrén väitti, että sanassa mordva oleva pääte -va tarkoittaa 'vettä; jokea', ja että sanan muroma pääte - $m a$ 'maata'. Indoiranilaisten voimakas vaikutus olisi ollut syynä siihen, että vielä marien ja mordvien 1800-luvun maanviljelysmagiassa on vahva indoeurooppalainen aines. Kyse ei ole itäslaavilaisesta vaan paljon vanhempaa perua olevasta lainasta, joka saattaa viitata siihen, että pohjoiseen työntyneitä indoiranilaisia populaatioita oli sulautunut suomalais-ugrilaisiin. Volgan seudun asukkaat alkoivat mahdollisesti tästä syystä lyhentää vähin erin sanoja lopusta, minkä seurauksena kaksitavuiset sanat lyhenivät yksitavuisiksi ja nelitavuiset kolmitavuisiksi. Näillä perustein olisi mahdollista väittää, että ikivanha oktosyllabinen mitta katosi siellä, missä indoiranilainen vaikutus oli suurinta kivikauden loppupuolella. Unohtumisen perussyynä olisi ollut kaksi- ja nelitavuisten sanojen väheneminen, jolloin näitä suosivan oktosyllabisen mittan käyttö ei tahtonut enää luonnistua. Tässä esitetty pohdinta ei kuitenkaan vakuuta. 


\section{Lopullinen hypoteesi}

Vaikka Suomesta katsottuna kaikkein kaukaisimpien intiaanien, Tulimaan selk'namien, šamaanilaulustossa esiintyy säännönmukaista oktosyllabisuutta ja vaikka Kuolan saamelainen saattaa väittää kuulleensa selk'namien lauluja naapurikylässään, tyylien yhtäläisyyteen liittyy sekä ikivanhoja että nuoria piirteitä. Väitän nimittäin, ettei oktosyllabisuus voi olla kovin vanha eikä vain kerran yhdessä paikassa syntynyt mitta, vaan että se on kehkeytynyt itsenäisesti monilla tahoilla. Esitän väittämän hypoteesina, joka vaatii tarkistuksia monitieteisellä tutkimusaineistolla.

Ajattelussani keskeistä on Mikko Korhosen edellä siteeraamani oletus, ettei painoajoitteisen kielen puhujan voi ajatella luontevasti kehittäneen laulukielensä pohjaksi tavuajoitteista mittaa. Painoajoitteinen kieli johtaa luonnostaan samankaltaiseen mittaan, joka siis on dynaaminen mitta. Niinpä koko tässä esitettävä hypoteesi pysyy tai kaatuu sen mukaan, miten uralilainen kantakieli prosodian näkökulmasta määritetään, ja Mikko Korhonen on olettanut sen painoajoitteiseksi. Koska sekä samojedien että suomalais-ugrilaisten nykykielet ovat pääosin tavuajoitteisia, muutokset prosodiassa (ja sen vuoksi myös laulujen teksteissä) ovat tapahtuneet viimeisten vuosituhansien aikana.

Emme tiedä, oliko uralilainen laulaja käyttänyt mitään erityistä mittaa, mutta tätä nykyä oktosyllabinen mitta tunnetaan laajalla maantieteellisellä alueella, jolla on kolme keskenään samankaltaista kieliperhettä. Myös mordvan mitan antama esimerkki viittaa siihen, ettei turkkilaisten tai tunguusien oktosyllabisuus voi olla geneettisessä suhteessa uralilaisten kansojen vastaavaan, vaan että se on kehittynyt näissä kolmessa kieliperheessä yhdenmukaiseksi samanlaisista kielensisäisistä syistä. Kuten mordvan oktosyllabisuus kehittyi erillään itämerensuomalaisesta, turkkilainen mitta on voinut kehittyä erillään tunguusilaisesta.

Suomalais-ugrilaisten kansojen laulustossa itkuvirttä ei näy esiintyneen obinugrilaisilla eikä komeilla eikä juurikaan saamelaisilla. Muihin suomalaisugrilaisiin kulttuureihin se on kuulunut. Toisaalta Siperian kansoilla ja intiaaneilla on ollut henkilökohtaisten laulujen traditio, joka taas on puuttunut itkuvirsikulttuureista. Näyttää siltä, kuin henkilölaulut olisivat käyneet maanviljelijöiden sosiaalisissa rakenteissa tarpeettomiksi ja itkut tulleet niiden tilalle. Itkuvirsi on kuulunut maanviljelijän kulttuuriin, henkilölaulut pyytäjien kulttuuriin. Tältä kannalta katsottuna henkilölaulut voidaan olettaa vanhimpien laululajien joukkoon. Tuntuu siltä kuin maanviljeljäsukujen välisissä suhteissa ja roolien sisäisessä hierarkiassa olisi tapahtunut muutoksia, jotka yhtäältä ohjasivat kunnioittamaan suvun vainajia ja toisaalta loivat sukujen välille uudenlaisia yhteyksiä, joista kärsimään joutui morsian. Suvut olivat sulkeutuneita, mutta avioliitot avasivat sulkuja, kun juuri nainen joutui jättämään oman sukunsa liittyäkseen uuteen ja outoon. Tähän saattaa kytkeytyä monenlaisia kulttuurisia mekanismeja, mutta yksi asia on varma: suvunvaihto oli naiselle 
yhtä traumaattinen kuin maailmanvaihto kuolleelle oli vaarallinen, mikä taas oli vaaraksi koko elävälle suvulle. Pyytäjien liikkuvan yhteiskunnan muututtua viljelijöiden hieman staattisemmaksi yhteiskunnaksi, yksilön identiteetti alkoi määräytyä paikan mukaan. Henkilölaulu näyttää jatkaneen olemassaoloaan itkuvirtenä, joka liittyi siirtymäriittien kahteen lajiin: kuoleman ja naisen avioitumisen riitteihin, joissa kummassakin subjektin "paikka" muuttui. Kun kuolleen paikka siirtyi Tuonnelaan ja naisen paikka miehelään, tapahtui myös identiteettimuutos. Ymmärtääkseni henkilölaulun katoamisen ja itkuvirren synnyn taustalla olikin juuri identiteettiin kohdistunut muutos, jossa yksilön pysyvä suhde (šamastuminen) luontoon, paikkaan, eläviin ja kuolleisiin, haltijoihin jne. muuttui ratkaisevasti. Kun väen ja haltijan rinnalle astui juma, henkilölaulu alkoi väistyä.

Tästä hypoteettisesta näkökulmasta katsottuna on kiintoisaa palata edellä tehtyyn havaintoon, jonka mukaan karjalainen itku pohjautuu kiinteää metriä vailla oleville säkeille, mikä sallii laulajan improvisoida melodian ja rytmin avulla. Tuloksena on vaihtelevan mittaisia säkeitä. Kuitenkin virren ja itkun välillä on yhteisiä piirteitä kuten laskeva suunta, pentakordinen modaalisuus, tekstin alkusointuisuus ja tekstin melodisen käsitelyn syllabinen perusluonne: yhtä tavua vastaa pääsääntöisesti yksi sävel. Viimeksi mainittu piirre erottaa karjalaisen itkun esimerkiksi kantaslaavilaista perua olevasta genrestä nimeltään protjažnaja pesnja eli 'venytetty laulu', joka vastaa turkkilaisten kansojen 'pitkän sävelen' genreä. Niin ikään itku eroaa luultavastikin jo kantabalttilaista perua olevasta melismaattisesta työlaulustosta kuten elonkorjuunsävelmistöstä. Kahdeksantavuisuuttahan Liettuan vanhoissa lauluissa ei esiinny.

Voidaankin tehdä se oletus, että itkuvirsi edustaa hyvin arkaaista tyyliä, samaa kuin arktinen henkilölaulu ja samaa tyyliä kuin uralilaisen kauden laulu, jonka edustajat painottivat sanan ensitavua ja jättivät muut tavut painottamatta. Itkuvirren ja leutten tyylit olisivat siis palautettavissa painoajoittaisen kielen dynaamiseen mittaan, joka näyttää olleen varsin vapaata ja jota ei sitonut tavujen lukumäärä. Itkuun kuten muihinkaan mainittuihin lajeihin ei kuitenkaan kuulu isokronia, sillä itkijä saattaa ajallisesti käsitellä pääpainon jälkeisiä tavuja aivan kuten parhaaksi näkee ja vapaana kiirehtimisen pakosta. Näkyykö itkuissa oletetun isokronian jälkiä? Se jää tulevan tutkimuksen vastattavaksi.

Pyrin siis tässä näkemään itkun arkaaisena reliktinä ja henkilölaulujen tyylin jatkajana. Sen suhteen kahdeksantavuinen runomitta vaikuttaa nuorelta. On vaikea sanoa, mitkä tekijät ovat ylipäätään saaneet ihmisen luomaan määrämittaisen metrisen systeemin ja sitoutumaan siihen. Syistä riippumatta sitoutuminen näyttää tapahtuneen pohjoisen Euraasian suurten agglutinoivien kieliperheiden alueilla. Otaksun oktosyllabisten mittojen paralleelikehityksen syyksi samankaltaiset kielisysteemit, joista kahdeksantavuisuus kumpusi luonnostaan silloin, kun syllabisen määrämitan synnyn muut edellytykset olivat olemassa. En väitä, etteikö turkkilaisen mitan synnyllä olisi geneettinen yhteys tunguusien mittaan. Totean vain, ettei yhteyttä ole nykytietoni valossa tarpeellista 
olettaa. Sen sijaan väitän, ettei oktosyllabisten samojedi- tai obinugrilaislaulujen synnyllä ole yhteyttä itämerensuomalaisten oktosyllabisen kalevalamitan syntyyn. Tältä kannalta voidaan todeta, ettei saamelaisesta musiikista ole tarvis etsiä kadonneen kahdeksantavuisuuden jälkiä, koska tällaista ei välttämättä ollut olemassa vielä kivikauden lopulla eikä pronssikaudella (ts. ei suomalaisvolgalaisena eikä varhaiskantasuomalaisena aikana), eikä se ole myöhemminkään tarttunut saamelaiseen perinteeseen. Toisaalta on edelleen selvittämättä se kysymys, mikä osa pohjoissaamelaisten joikuperinteessä on uralilaista perua, mikä taas on Fennoskandian kaikkein alkuperäisimmän väestön substraattiainesta.

On selvä, että oktosyllabisuuden symboliset merkitykset olivat tärkeitä. Mittaa ei käytetty kuin aivan tietyissä ympäristöissä eikä koskaan muutoin kuin laulaen. Se oli alun alkaen ollut sakraalikielen koodi (siis esim. myyttien kerronnan väline), joka tuon sakraalin hämärryttyä oli levinnyt muihinkin, joskaan - itämerensuomalaisia lukuun ottamatta - ei aivan yhdentekeviin yhteyksiin. Koska euraasialaiseen kahdeksantavuisuuteen ei ole kiinnitetty erityishuomiota missään tuntemassani tutkimuksessa, monien kysymysten selvittely jää tässä kesken. Tällaisia ovat $\mathrm{mm}$. kysymys siitä, onko mitta liittynyt oireellisen vahvasti šamanismiin myös turkkilaisissa ja tunguusilaisissa kulttuureissa, missä muissa yhteyksissä sitä Euraasiassa on käytetty kuin edellä painotetuissa laulutarinoissa ja šamaanilauluissa, ja onko kahdeksantavuisen pohjakaavan toteutumien edellä esitelty typologia validi? Voidaanko puhua kahdeksantavuisuudesta yleensä, vai pitäisikö tarkastella vain nelipolvitrokeeta? Ovatko kaikki olettamani systeemit edes tulkittavissa kahdeksantavuisiksi? Miten suhtautua daktyylisiin runojalkoihin: kuuluvatko ne systeemiin? Onko komeilta ja udmurteilta todella puuttunut itkuperinne? Onko turkkilaisilla ollut itkuvirttä? Miltä näyttää etnomusikologiselta kannalta suhde slaavilaisen ja suomalais-ugrilaisen itkun välillä? Voidaanko puhua suomalais-ugrilaisesta itkusta?

Musiikillisesti kahdeksantavuisen mitan tyylipiirteet ovat yllättävän samanlaiset koko valtavalla alueella: yksi- ja kaksisäkeisesti etenevä ja vain lievästi varioiva jatkumo etenee yleensä kolmen, neljän tai viiden vierekkäisen sävelen avulla joko diatonisessa tai pentatonisessa ympäristössä. Tältä kannalta katsottuna runolaulun tyyli ulottuu Tyynelle merelle asti. Kun laulajat ovat perinteisesti käyttäneet muissakin laululajeissa vain muutamia säveliä, ei ole mielestäni millään lailla yllättävää, että - oletukseni mukaan - eri puolilla Euraasiaa itsenäisesti eri aikoina tapahtuneen rinnakkaiskehityksen seurauksena tähän mittaan on liimautunut myös samanlaisia musiikillisia tyylejä. Neljän painon ja neljän laskun varaan asettunut mitta on ollut niin vahva, että se on pakottanut myös melodian poljennon seuraamaan itseään. Näin tyyliyhtäläisyydet ovat seurausta samanlaisista lähtöaineksista, eivät sukulaisuudesta.

Moodien asteikot on toisinaan koottu pentatonisesta pohjasysteemistä, vaikka varsinaista pentatoniikkaa ei esiinny. Tilanne on monimutkainen, enkä uskalla siitä tässä paljon sanoa, mutta ainakin osaa tapauksista voi arvella 
suhteellisen myöhäiseksi lainaksi tunguusilaiselta ja mongolilaiselta taholta. Asia vaatisi kunnon aineistolla tehdyn analyysin. Kuitenkin se seikka, että moodit toimivat vain muutaman vierekkäisen sävelen avulla viittaa mahdollisuuteen, että näiden alueiden musiikki oli alun alkaen ollut tri-, tetra- ja pentakordista.

Kiinnostavasti tunguuseille on ominaista mitan supistava toteuttaminen, ts. säkeessä on neljä painoa, mutta tavuja on vähemmän kuin kahdeksan. Toisaalta samojedien, obinugrilaisten ja mordvalaisten soveltamistavalle on ominaista lavennus: pohjakaavaa häivytetään lisäämällä tekstiin ylimääräisiä tavuja, joilla useimmiten ei ole leksikaalista tehtävää. Laventamisen keskittyminen juuri Uralin molemmille puolille saattaa olla oire, jonka mahdollisten syiden etsintä saattaa paljastaa uutta näiden alueiden musiikista. Oliko tässä häivyttämisessä pyrkimys hämätä vahingollisia voimia naamioimalla sakraali koodi näkymättömiin?

\section{P.S.}

Yllä oleva ajatusmalli viittaa siis siihen mahdollisuuteen, että kolttien leutte edustaisi samaa kivikautista tyylirypästä kuin karjalainen itku ja monet Siperian lajit. Toisaalta se olisi pyytäjäkulttuurin nykyinen edustaja. Kalevalamittainen virsi olisi puolestaan jo maanviljelyskulttuurin edustaja. Maan hyödyntäminen viljelyyn oli subarktisilla alueilla epäilemättä vaatinut pitkällisiä ja syvällisiä yhteyksiä sellaisiin populaatioihin, jotka hallitsivat alkeisenkin viljelyn. Täten kaski- ja maanviljelyn ei sinänsä voi nähdä mittaan sitoutumisen syyksi. Pohjimmaisena syynä olisivat enemmänkin olleet viljelytekniikan ympärille kasatut uudet ajattelumallit, jotka tuon tekniikan omaksunut väestö sai kaupanpäällisiksi. Tarkoitan tässä esimerkiksi uutta maailmankuvaa jumalauskoineen, uusine ajanlaskutapoineen ja magian uusine sisältöineen. Tähän kompleksiin on hyvinkin saattanut kuulua pyrkimys hallita maailmankaikkeutta uudella tekniikalla, metriin sidotulla maagisella laulutekstillä.

Oletus ei selkeytä lainkaan yleistilannetta, sillä sen kummemmin turkkilaiset kuin tunguusitkaan eivät olleet viljelijöitä. Eivätkä maanviljelyyn jo ennen itämerensuomalaisia tutustuneet volgalaiset tunteneet kahdeksantavuisuutta, joka yleensä on liittynyt šamanismiin, ei maanviljelyyn. Toisaalta pyrkimys kytkeä mitta viljelyyn saattaa olla hedelmällinen, jos lähtee siitä, että tekstin sitominen metriin oli syntynyt eteläisen Aasian ja koillisen Afrikan maanviljelijäin vauraissa yhteiskunnissa, joiden vaikutus oli alkanut muuttaa subarktisia kulttuureita jo tuhansia vuosia sitten siitä riippumatta, välittivätkö näiden edustajat minkäänlaisesta viljelystä. Tältä kannalta katsottuna on aivan mahdollista, että uralilaiset, tunguusit ja turkkilaiset alkoivat kehittää mittaa, joka sopi heidän kielisysteemeihinsä. Tuloksena oli oktosyllabisuus. Tältä kannalta katsottuna se Matti Kuusen ajatus ${ }^{56}$, johon hän oli päätynyt laulujen tekstejä 
analysoimalla, ja jonka hän kruunasi sananlaskujen kielen antamalla tiedolla, on yhä ajankohtainen: "Suomalais-volgalaisen kauden päättyessä - 2. esikristillisellä vuosituhannella varhaiskantasuomalaisilla oli itkujen, joikujen ja karjanhuhuilujen ohella jokin esisuomalainen alkusointua ja kertoa viljelevä, epäkiinteä tai mahdollisesti neli-iskuisiksi säkeiksi jaksottuva myyttiepiikan ym. rituaalitekstien esittämiskoodi. Sen jälkiä olisi ehkä löydettävissä lappalaisten ja vepsäläisten metriikasta.".

Musiikin-, tekstin- ja kielentutkimuksen yhteistyö on tarpeen ei ainoastaan itämerensuomalaisen alueen sisällä vaan koko pohjoisessa Euraasiassa. Omilla nurkillamme kiirehtisin karjalaisen ja vepsäläisen itkun sekä kuolansaamelaisen laulun vertailevaa analyysiä.

\section{Viitteet}

1 Posti 1953.

2 Ks. aiheesta Leisiö 1989.

3 Viimeksi kai Honko 1993, 53-57.

4 Aiheesta enemmän Kuusi 1978.

5 Kolehmainen 1977; Rüütel 1977 (Vatja), Rüütel 1980 (Viro).

6 Ks. esim. Lippus 1993; Väisänen 1944; Leisiö 1976, 244-250.

7 Ks. Kolehmainen 1977, 86-96 ja 163-167. Ks. myös Tawaststjerna 1989, 306-315.

8 Heikki Laitisen kahdenkeskinen kommentti keväällä 1995.

9 Lükő 1963.

10 MSS puoli 3: n:o 62-64.

11 Anonyymi japanilainen julkaisu, jossa on ainujen laulusävelmiä. Tekstit on kirjoitettu japanilaisin kirjaimin. Valokopiona 1974 saamassani kopiossa ei ole nimiösivuja. Tämä laulu lienee sivulta 42 .

12 Sama kirjanen, sivu 46.

13 Ks. esim. Leisiö 1993.

14 MSS, sivu 2, n:o 35.

15 MÍA, sivu 1 , raita 1 .

16 Evenkien ja eveenien metriikasta lähteenä on vain Levin et Potapov 1964.

17 Aiemmin (Leisiö 1993, 15, 22 et passim ) olen nimittänyt tätä kansaa mm. nimillä ude ja udegei. Tässä on virhe, joka johtuu siitä, että näin ne olivat venäjänkielisissä lähteissäni. Venäjästä puuttuu $h$-äänne, ja sen sijalle venäläinen sijoittaa $g$-äänteen. Siksi Hitleristä tulee Gitler. Tämän kansan todelliset nimivariantit ovat siis udee, udihe ja udehe.

18 Novosibirskin konservatorion arkisto, 1990-luku. Juri Šeikinin luovuttama kopio on löydettävissä Kansanperinteen laitoksesta (Ude IA).

19 MSS: puoli 2, nr:o 44.

20 Mamedov 1984, 39-40. 
21 Altailaisten turkkilaiskansojen ja heimojen moninaisuuden vuoksi kansojen nimistö on sekava. Altailaiset asuvat Vuori- eli Gorno-Altailla. Useiden kansojen nimissä esiintyy sana kiži, joka tarkoittaa ihmistä. Niinpä altai-kiži tarkoittaa 'Altain ihmistä' ja maima-kižit 'Maima-joen ihmistä'. Eteläaltailaisia heimoja ovat altait (kižit), joiden nimenä mainitaan toisinaan mongolilaisen oiratti-heim on perusteella esiintyvä oirootti, sekä telet, teleutit ja telengiitit. Pohjoisaltailaisia ovat $\mathrm{mm}$. kumandiinit, šoorit ja tubalaarit. (Jarkko Niemen tarkennus suullisesti; Vaba 1993: s.v. altailased).

Tubat eli tofalarit tuntevat useita nimiä, mikä johtuu heimon taustasta. Nimi liittyy samojedeihin kuuluvan nenetsikansan tuva-eli tuba-nimiseen heimoon. Se oli siirtynyt etelään ja turkkilaistunut (pääte -lar on turkin monikko). Kansa, johon nämä samojedit sulautuivat, kuului hakasseihin ja kutsui itseään nimellä karakaš. Siten esim. kirjallisuudessa tavanomainen nimitys "tuvalainen" on sama kuin tubalainen, tofalainen tai karakaššilainen. (Vaba 1993: s.v. tofalarid).

22 Ks. Aksenov 1973; Walcot 1974.

23 Aksenov 1964, n:o 71.

24 Stojanov 1980, n:o 5.

25 Stojanov 1980, n:o 1.

26 Ks. esim. Stojanov 1980, 30.

$27 \mathrm{YMF}$, puoli 1, raita 2.

28 Äänitteen kopio on Kansanperinteen laitoksessa: Kasetti Yakut 1-13, B.

29 YMF puoli 1: raita 7.

30 KRS n:o 173.

31 MSS: puoli 3, raita 62 .

32 Janhunen 1986.

33 Niemi 1992. Tässä kiitän Jarkko Niemeä avusta, jota hän on tarjonnut sekä samojedikieliin että turkkilaisiin kieliin liittyneissä ongelmissani.

34 Niemi 1993.

35 Helimski 1989.

36 Nojaudun tässä Eugen Helimskin luentoihin Kansanperinteen laitoksessa marraskuussa 1992. Luennot julkaistaan suomen kielellä lähitulevaisuudessa.

37 Ojamaa 1990.

38 Dobžanskaja 1989.

39 Asiasta on kirjoittanut Korhonen 1983, 133-152.

40 Niemi 1992, mm. 54-62, 88-89.

41 Niemi 1992, näyte 29. Tässä julkaisemani notaatio eroaa hieman Niemen tulkinnasta.

42 Väisänen 1939.

43 Lázár 1988, 281-296.

44 Lázár 1988, 290: ex. 9, rivi 3.

45 Lázár 1988, 290: ex. 8.

46 KhP: puoli 1, raita 6. Laulaja, Galina Vagat oli syntynyt 1947 Kazymin kylässä. 
47 Mordvalaisen musiikin keskeiset antologiat ovat Bojarkin 1981 ja 1984 sekä Bojarkina 1988.

48 Kolk 1979.

49 Rüütel 1990.

50 Korhonen 1987.

51 Uralilaisella kaudella tarkoitan aikaa, jolloin kaikkien samojedien ja suomalais-ugrilaisten kielelliset esi-isät puhuivat yhtä kieltä. Volgalaisella kaudella tarkoitan aikaa, jolloin saamelaisten, itämerensuomalaisten sekä Volgan alueen marien, mordvien jne. esivanhemmat puhuivat vielä samaa kieltä. Alueellisesti viimeksi mainittu lienee vastannut kampakeramiikan jälkivaihetta. Noin 3000 vuotta sitten äärialueilla kieli oli muuttumassa jo siinä määrin, että Itämeren väestön puheenpartta voidaan pitää eri kielenä kuin Volgan. Aiheesta enemmän: Laakso 1991.

52 Kieli on agglutinoiva eli 'liimaava', jos kieliopillisia suhteita ilmaistaan kiinnittämällä sanan hännäksi liitännäisiä eli affikseja: silmä $\leftarrow s s \ddot{\leftarrow} \leftarrow n i$. Esimerkiksi englannissa kieli toimii toisin, ja määritteet ovat ennen pääsanaa: in $\rightarrow$ my $\rightarrow$ eye.

53 Korhonen 1987, 182.

54 Napolskih 1989.

55 Lukuisia kirjoituksia sisältää kokoelma Emsheimer 1964. Ks. myös Emsheimer 1979 sekä 1991.

56 Kuusi 1978, 223.

\section{Lähteet}

Aksenov, A. N. 1964. Tuvinskaja narodnaja muzyka. Moskva.

Aksenov, A. N. 1973. Tuvin Folk Music. Asian Music, vol. 4.

Bojarkin, N[ikolai] I. 1981. Pamjatkniki mordovskogo narodnogo muzykal'nogo iskusstva. Tom I. Saransk.

Bojarkin, N[ikolai] I. 1984. Pamjatkniki mordovskogo narodnogo muzykal'nogo iskusstva. Tom II. Saransk.

Bojarkina, L[udmila] B. 1988. Pamjatkniki mordovskogo narodnogo muzykal'nogo iskusstva. Tom III. Saransk.

Comrie, Bernard 1981. The Languages of the Soviet Union. Cambridge: Cambridge University Press.

Dobžanskaja, O[ksenja]. Je. 1988. Melodika nganasanskih kejngejrsja. Muzykal 'naja etnografija severnoj Azii. (Ot. red. Ju. Šejkin) Mežvuzovskij sbornik naužnyh trudov. Vyp. 10. Novosibirsk.

Emsheimer, Ernst 1964. Studia ethnomusicologica eurasiatica. Stockholm: Musikhistoriska museet.

Emsheimer, Ernst 1979. Schamanentrommel. Die Musik in Geschichte und Gegenwart. Band 16. Kassel. 
Emsheimer, Ernst 1991. On the Symbolism of the Lapp Magic Drum. Studia ethnomusicologica eurasiatica II. Stockholm: Kungl. Musikaliska Akademin.

ERMA. Eesti rahvamuusika antoloogia (toim. Ingrid Rüütel). Melodija M30 46729 004, Tallinn 1986.

Helimski E[vgeni]. A. 1989. Sillabika stiha v nganasanskih inoskazatel'nyh pesnjah. Muzykal'naja etnografija severnoj Azii. (Ot. red. Ju. Šejkin). Mežvuzovskij sbornik nauyžnyh trudov. Vyp. 10. Novosibirsk.

Helimski 1992. Eugen Helimskin luentosarja Kansanperinteen laitoksessa marraskuussa 1992. Luennot ilmestyvät suomeksi lähitulevaisuudessa.

Honko, Lauri 1993. Oral Poetry: The Comparative Approach. The Great Bear. Helsinki: SKS.

Janhunen, Juha 1986. Glottal Stop in Nenets. SUST 196. Helsinki.

KhP. Khantyiskie pesni. Melodija 33 C 30-10877-8. Toim. Igor Brodski. 1980-luku.

Kolehmainen, Ilkka 1977. Kalevalansävelmän musikologista syntaksia. Pro gradu- ja sivulaudaturtyö: Helsingin yliopisto.

Kolga, Margus, Igor Tõnurist, Lembit Vaba, Jüri Vikberg (toim.) 1993. Vene impeeriumi rahvaste punane raamat. Tallinn.

Kolk, Udo 1979. Setu mitmehäälsuse probleeme. Regivärs. Töid eesti filoloogia alalt VI. Tartu Riikliku Ylikooli Toimetised. Vihik 501. Tartu.

Korhonen, Mikko 1983. Kolttalaulujen fonologiaa. Suomalais-ugrilaisen Seuran Aikakauskirja 78. Helsinki.

Korhonen, Mikko 1987. Kalevalamitan varhaishistoriaa. Journal de la Société Finno-Ougrienne 81. Helsinki.

KRS Karjalan runosävelmät. Julkaissut Armas Launis. Helsinki: SKS.

Kuusi, Matti 1978. Kalevalakielen kysymyksiä. Virittäjä 3.

Laakso, Johanna (toim.) 1991. Uralilaiset kansat. Porvoo - Helsinki - Juva: WSOY.

Lázár, Katalin 1988. Structure and Variation in Ob-Ugrian Vocal Folk Music. Studia Musicologica Academiž Scientiarum Hungaricž 30. Budapest.

Lehtisalo, Toivo 1947. Juraksamojedisches Volksdichtung. Helsinki.

Leisiö, Timo 1976. Kalevalaisen kansanlaulun ulottuvuuksia. Juhlakirja Erik Tawaststjernalle 10. X. 1976. Toim. Erkki Salmenhaara. Acta Mus. Fenn. 9. Keuruu.

Leisiö, Timo 1989. Runoin jäljillä eli perinteemme todellisuuksien selityksiä etsimässä. Vaijeritemppu. Ilpo Saunion juhlakirja 1.4.1989. Toimittaneet Vesa Kurkela ja Anu Luukkonen. Helsinki.

Leisiö, Timo 1993. "Č'ipč'irgan kad' kuaram'e." Tietoja arvoituksellisesta imutrumpetista. Etnomusikologian vuosikirja 5.

Levin, M.G. et Potapov, L.P. (ed.) 1964. The Peoples of Siberia. Chicago and London.

Lippus, Urve 1993. Kalevalamittaisen runolaulun rytmilaeista II. Etnomusikologian vuosikirja 5. 
LRA Lahemaa rahvamuusika ansambel. Melodija C32 23363 009. Tallinn 1986. Lükő, Gábor 1963. Az indo-európai óskor zenei hangrendszerének emlékei a Finnugor népek folklórjában. Käsikirjoitus. Tutkielma on julkaistu ranskaksi sarjassa Etudes Finno-ougriennes. Tome II. Fasc. 1. Paris 1965, sivuilla 35-66. Tutkielman on suomentanut Kansanperinteen laitoksessa Eija Kukkurainen ja se on tarkoitus saada julkisuuteen muutaman muun unkarilaisen artikkelin kera.

Mamedov, Tariel' 1984. Pesni keroglu. Baku.

MSS. Muzyka severnogo sijan'ja. (Toimittanut Igor Bogdanov.) Melodija C90 30129 001. 1990 Moskva.

Napolskih, V. V. 1989. The Diving-Bird Myth in Northern Eurasia. Uralic Mythology and Folklore. (Ed. by M. Hoppál and J. Pentikäinen). BudapestHelsinki.

Niemi, Jarkko 1992. Nenetsien musiikkikulttuuri: laulut ja soittimet. Lisensiaattityö. Tampereen yliopisto, Kansanperinteen laitos.

Niemi, Jarkko 1993. Kai Donnerin tallentamat selkuppi- ja kamassisamojedilaulut A.O. Väisäsen "Samojedicshe Melodien" -nuotinnosjulkaisussa. Etnomusikologian vuosikirja 6.

Ojamaa, Triinu 1990. The Nganasan Improvisatory Chants. Preprint KKI-64. Tallinn.

Posti, Lauri 1953. From Pre-Finnic to Late Proto-Finnic. Finnisch-ugrische Forschungen XXXI: 1-2. Helsinki.

Rüütel, Ingrid 1977. Vadja rahvamuusika tüpoloogia ja stiilid. Soome-ugri rahvaste muusikapärandist. Toim. I. Rüütel. Tallinn.

Rüütel, Ingrid 1980. Mustjala regiviiside tüpoloogia. Tallinn.

Rüütel, Ingrid 1990. Die Schichten des Volkslieds der Setukesen und ihre ethnokulturellen Hintergründe. Finnisch-ugrische Forschungen XLIX. Helsinki.

Rüütel, Ingrid 1992. Virolaisen kansanmusiikin historialliset kerrostumat ja tyylit. Etnomusikologian vuosikirja 4.

Rüütel, Ingrid et Jaan Ross 1985. A Study of Pitch Contours and the Scale Structure in Votic Folk Music. Preprint KKI-37. Tallinn.

Stojanov, A. 1980. Tofalarskie narodnie pesni. Materialy fol 'klornyh ekspedicij 1975-1976 gg. Irkutsk.

Tawaststjerna, Erik 1989. Jean Sibelius I. (2. painos.) Helsinki: Otava.

Walcot, R. 1974. The Chöömij of Mongolia: a spectral analysis of overtone singing. Selected Reports in Ethnomusicology 2.

VIR. Vadja ja Isuri Rahvalaule (Toim. Ingrid Rüütel). Melodija M30-411278. Tallinn 1982.

Väisänen, A. O. 1939. Untersuchung über die Ob-ugrischen Melodien. Mémoires de la Société Finno-ougrienne LXXX. Helsinki.

Väisänen, A. O. 1944. Kalevalamitta ja runosävelmät. Virittäjä 3.

YMF. Iz Yakutskogo muzykal'nogo fol'klora. Melodija D 030639-40. 